The present manuscript is a non-peer reviewed preprint submitted to EarthArXiv. Please note that this manuscript has been submitted to GSA Bulletin for peer review. Subsequent versions of this manuscript may have slightly different content. If accepted, the final version of this manuscript will be available via the "Peer-reviewed Publication DOI" link on the right-hand side of this webpage. Please feel free to contact the authors, we welcome feedback.

\title{
A one-million-year isotope record from siderites formed in
} modern ferruginous sediments

Vuillemin A. ${ }^{1 *}$, Mayr C. ${ }^{2,3}$, Schuessler J.A. ${ }^{1,4}$, Friese A. ${ }^{1}$, Bauer K.W. ${ }^{5,6}$, Lücke A. ${ }^{7}$, Heuer V.B. ${ }^{8}$, Glombitza C. ${ }^{9}$, Henny C. ${ }^{10}$, von Blanckenburg F. ${ }^{1}$, Russell J.M. ${ }^{11}$, Bijaksana S. ${ }^{12}$, Vogel H. ${ }^{13}$, Crowe S.A. ${ }^{5,14}$, and Kallmeyer J. ${ }^{1}$

${ }^{1}$ GFZ German Research Centre for Geosciences, Helmholtz Centre Potsdam

${ }^{2}$ Friedrich-Alexander Universität Erlangen-Nürnberg, Institut für Geographie

${ }^{3}$ Ludwig-Maximilians-Universität München, Department of Earth \& Environmental Sciences, Paleontology \& Geobiology

${ }^{4}$ Present address: Thermo Fisher Scientific, 28199 Bremen, Germany

${ }^{5}$ Department of Earth, Ocean, and Atmospheric Sciences, University of British Columbia

${ }^{6}$ Department of Earth Sciences, University of Hong Kong

${ }^{7}$ Research Center Jülich, Institute of Bio- and Geosciences

${ }^{8}$ MARUM - Center for Marine Environmental Sciences, University of Bremen

${ }^{9}$ ETH Zürich, Institute of Biogeochemistry and Pollutant Dynamics

${ }^{10}$ Research Center for Limnology, Indonesian Institute of Sciences (LIPI)

${ }^{11}$ Department of Earth, Environmental, and Planetary Sciences, Brown University

${ }^{12}$ Faculty of Mining and Petroleum Engineering, Institut Teknologi Bandung

${ }^{13}$ Institute of Geological Sciences \& Oeschger Centre for Climate Change Research, University of Bern

${ }^{14}$ Department of Microbiology and Immunology, University of British Columbia

*Corresponding author: Dr. Aurèle Vuillemin

Email address: aurele.vuillemin@gfz-potsdam.de

Keywords: siderite, vivianite, combined isotopes, ferruginous system, Late Quaternary, Lake Towuti, ICDP. 


\section{A one-million-year isotope record from siderites formed in modern 2 ferruginous sediments}

3 Aurèle Vuillemin ${ }^{1 *}$, Christoph Mayr ${ }^{2,3}$, Jan A. Schuessler ${ }^{1,4}$, André Friese ${ }^{1}$, Kohen W. Bauer ${ }^{5,6}$, Andreas

4 Lücke $^{7}$, Verena B. Heuer ${ }^{8}$, Clemens Glombitza ${ }^{9}$, Cynthia Henny ${ }^{10}$, Friedhelm von Blanckenburg ${ }^{1}$, James M.

5 Russell $^{11}$, Satria Bijaksana ${ }^{12}$, Hendrik Vogel ${ }^{13}$, Sean A. Crowe ${ }^{5,14}$, and Jens Kallmeyer ${ }^{1}$.

6

$7 \quad{ }^{1}$ GFZ German Research Centre for Geosciences, Helmholtz Centre Potsdam, Telegrafenberg, 14473

8 Potsdam, German

$9 \quad{ }^{2}$ Friedrich-Alexander Universität Erlangen-Nürnberg, Institut für Geographie, D-91058 Erlangen,

10 Germany

11

${ }^{3}$ Ludwig-Maximilians-Universität München, Department of Earth \& Environmental Sciences, Paleontology \& Geobiology, Munich, Germany

${ }^{4}$ Present address: Thermo Fisher Scientific, 28199 Bremen, Germany

${ }^{5}$ Department of Earth, Ocean, and Atmospheric Sciences, University of British Columbia, 2350 Health

Sciences Mall, Vancouver, BC, Canada

${ }^{6}$ Department of Earth Sciences, University of Hong Kong, Hong Kong, China

${ }^{7}$ Research Center Jülich, Institute of Bio- and Geosciences, IBG-3: Agrosphere, 52428 Jülich, Germany

${ }^{8}$ MARUM - Center for Marine Environmental Sciences, University of Bremen, Leobener Straße 8, D-28359 Bremen, Germany

${ }^{9}$ ETH Zürich, Institute of Biogeochemistry and Pollutant Dynamics, 8092 Zürich, Switzerland

${ }^{10}$ Research Center for Limnology, Indonesian Institute of Sciences (LIPI), Jl. Raya Bogor, Cibinong, Bogor, West Java 16911, Indonesia

${ }^{11}$ Department of Earth, Environmental, and Planetary Sciences, Brown University, 324 Brook Street, Providence, RI, USA

${ }^{12}$ Faculty of Mining and Petroleum Engineering, Institut Teknologi Bandung, 15 Bandung, 50132 Indonesia ${ }^{13}$ Institute of Geological Sciences \& Oeschger Centre for Climate Change Research, University of Bern, Baltzerstrasse 1-3, 3012 Bern, Switzerland

${ }^{14}$ Department of Microbiology and Immunology, University of British Columbia, 2350 Health Sciences Mall, Vancouver, BC, Canada

*Corresponding author: Dr. Aurèle Vuillemin

Email address: aurele.vuillemin@gfz-potsdam.de 
Ancient iron formations hold important records of environmental conditions during the Precambrian Eons. Reconstructions of past oceanic systems require investigating modern ferruginous analogs to disentangle water column and diagenetic signals recorded in iron-bearing minerals. We analyzed oxygen, iron, and carbon isotopes in siderite, a ferrous carbonate phase commonly used as an environmental proxy, from a 100-m-long record spanning a one-million-year depositional history in ferruginous Lake Towuti, Indonesia. Combining bulk sediment and pore water geochemistry, we traced processes controlling siderite isotope signatures. We show that siderite oxygen isotope compositions $\left(\delta^{18} \mathrm{O}\right)$ reflect in-lake hydrological and depositional conditions. Low iron isotope values $\left(\delta^{56} \mathrm{Fe}\right)$ record water column oxygenation events over geological timescales, with minor diagenetic partitioning of Fe isotopes by microbial iron reduction after deposition. The carbon isotope compositions $\left(\delta^{13} \mathrm{C}\right)$ reflect incorporation of biogenic $\mathrm{HCO}_{3}{ }^{-}$consistent with sediment organic matter remineralization lasting over $\sim 200 \mathrm{ka}$ years after burial. Positive $\delta^{13} \mathrm{C}$ excursions indicate increased biogenic production of methane that escaped the sediment during low lake levels. Diffusion across the sediment-water interface during initial formations of siderite tends to align the isotope signatures of bottom waters to those of pore waters. As microbial reduction of ferric iron and oxidation of organic matter proceed and saturate pore water conditions with respect to siderite, overgrowth on nuclei partially mutes the environmental signal inherited from past bottom waters over $\sim 1 \mathrm{Ma}$. Because high depositional fluxes of ferric iron and organic matter in early oceans would have promoted similar microbial processes in ferruginous deposits prior to lithification, the environmental record contained in siderite grains can successively integrate depositional and early diagenetic signals over short geological timescales.

\section{INTRODUCTION}

The mineralogy of Precambrian iron formations has commonly been used to infer atmospheric and oceanic conditions on early Earth (Klein, 2005; Holland, 2006; Canfield et al., 2008; Poulton and Canfield, 2011; Swanner et al., 2020). These iron formations are comprised of a diverse array of iron-bearing minerals including oxides, silicates and carbonates. Some of these minerals may form as pelagic precipitates (Poulton et al., 2004; Klein, 2005; Holland, 2006; Raiswell et al., 2011), but others are the products of early diagenetic recrystallization of primary ferric-ferrous iron (oxyhydr)oxides, as well as later-stage metamorphic reactions (Bekker et al., 2014; Halevy et al., 2017). Microbial Fe respiration, in particular, contributes to diagenesis in ferruginous sediments, and can drive formation of diagenetic iron carbonates that can be difficult to distinguish from primary precipitates (Johnson and Beard, 2008; Johnson et al., 2013; Posth et al., 2014; Vuillemin et al., 2019a). Formation of such diagenetic minerals (Ohmoto et al., 2004; Rosing et al., 2010; Kump et al., 2011; Bachan and Kump, 2015) can be spatially and temporally decoupled 
from contemporaneous ocean-atmosphere conditions (Anbar, 2004; Reinhard and Planavsky, 2011; Lyons et al., 2014). Due to the scarcity of ferruginous (Fe-rich, $\mathrm{SO}_{4}$-poor) environments on Earth today, studies distinguishing primary environmental signals related to water column authigenesis from secondary signals resulting from sediment early diagenesis remain scarce (Johnson et al., 2013; Posth et al., 2014; Swanner et al., 2020).

Ferruginous sediments have been deposited at the bottom of Lake Towuti on Sulawesi Island, Indonesia (Fig. 1A), over the last million years (Ma) or more (Russell et al., 2020). Ultramafic rocks and lateritic soils eroded from the catchment (Fig. 1B) supply these lakes with little sulfate but appreciable amounts of detrital iron (oxyhydr)oxides (Crowe et al., 2008a; Golightly, 2010; Hasberg et al., 2019; Morlock et al., 2019). Modern Lake Towuti is permanently stratified with anoxic ferrous Fe-replete bottom waters (Fig. 1C), thereby constituting a useful analog of the oxygen-depleted ferruginous conditions of the early oceans (Crowe et al., 2008b; Busigny et al., 2014). Siderite $\left(\mathrm{FeCO}_{3}\right)$ is a major constituent of ancient iron formations (Ohmoto et al., 2004; Kump et al., 2011; Johnson et al., 2013) that can be found sporadically at high concentrations, up to $35 \mathrm{wt} \%$, in Lake Towuti's sediment (Figs. 2A-3A). This siderite-rich sediment makes it possible to characterize the processes and environmental conditions that influence siderite properties during formation and burial (Vuillemin et al., 2019a). Although the distribution of siderites down core results from in-lake environmental conditions and variable fluxes of ferric iron and organic matter (OM) to the sediment (Russell et al., 2020), it may further reflect redox changes at the sediment-water interface (SWI) as well as non-steady-state diagenesis during entombment (Vuillemin et al., 2019a, 2020).

We attempt to disentangle the isotope signatures of siderites in Lake Towuti's sediment that are inherited from past environmental conditions (Severmann et al., 2006, 2008; Wittkop et al., 2014) from those imprinted during early post-depositional processes (Mozley and Wersin, 1992; Johnson et al., 2013; Posth et al., 2014). We use isotope signatures presently recorded in siderites to infer hydrological changes in Lake Towuti, such as stratification events and lake level fluctuations, in relation to climatic cycles (Russell et al., 2020; Ulfers et al., 2021; Morlock et al., 2021), and trace the influence of the biogeochemistry (Vuillemin et al., 2016; Bauer et al., 2020) and geomicrobiology (Bray et al., 2017; Vuillemin et al., 2017, 2018; Friese et al., 2021) in these modern ferruginous sediments with detailed pore water geochemistry, bulk reactive iron and organic carbon. Based on combined siderite $\mathrm{O}-\mathrm{Fe}-\mathrm{C}$ isotopes, we reconstruct biotic and abiotic processes of fractionation controlling siderite isotope signatures arising from $\sim 1 \mathrm{Ma}$ of depositional history in Lake Towuti and exposure of the corresponding ferruginous sequence to microbial Fe reduction and OM oxidation. This allows assessment of the influence of early diagenetic processes versus paleoenvironmental conditions. We thereby aim to determine the validity of siderite as primary mineral indicator for Quaternary and Precambrian ferruginous aquatic conditions. 


\section{STUDY SITE AND METHODS}

\section{Drilling campaign and core processing}

The International Continental Scientific Drilling Program (ICDP) coring operations of the Towuti Drilling Project (TDP) were carried out from May to July 2015, using ICDP's Deep Lakes Drilling System (Russell et al., 2016). Hole TDP-TOW15-1A (156 m water depth; hereafter TDP-1A) was drilled in May 2015 with a fluid contamination tracer (Friese et al., 2017) used to aid geomicrobiological sampling and analysis (Vuillemin et al., 2010; Kallmeyer, 2017). In total, $113 \mathrm{~m}$ of core were retrieved and sampled in the field under controlled conditions. Over 450 samples were taken immediately upon recovery and processed in the field for analyses of pore water chemistry and organic geochemistry. Core catchers were also packed into gas-tight aluminum foil bags flushed with nitrogen gas and heat-sealed to keep them under anoxic conditions until mineral extraction in the home lab. In January 2016, the unsampled remainders of the core were split, scanned and imaged at the Limnological Research Center, Lacustrine Core Facility (LacCore), University of Minnesota, using a Geotek Geoscan-III with line-scan CCD cameras, described macroscopically and microscopically to determine their stratigraphy and composition (Russell et al., 2016, 2020; Ulfers et al., 2021), and then subsampled.

\section{Pore water analyses}

Pore water was extracted on site from whole round core sections $(5 \mathrm{~cm} \times 6.6 \mathrm{~cm})$ in an anaerobic chamber after scraping off the rims with a sterile spatula. Rhizon samplers (Ejkelkamp, The Netherlands) were inserted into the soft sediment and pore water drained into a vacuum syringe. For denser sediment, we used a hydraulic press (Carver Inc., Wabash, United-States) and squeezed out the pore water as previously described (Vuillemin et al., 2020). Pore water was filtered through a sterile $0.2 \mu \mathrm{m}$ Minisart syringe filter (Sartorius, Germany) and collected in a glass syringe pre-flushed with nitrogen. All core sections were checked for contamination that could potentially be caused during drilling operations. Samples from contaminated sections were identified by optical quantification of fluorescent particles of the artificial tracer added to the drilling mud, as described in (Friese et al., 2017), and discarded.

$\mathrm{Fe}^{2+}$ concentrations were measured in the field using $1 \mathrm{~mL}$ of pore water with $100 \mu \mathrm{L}$ of Ferrozine Iron Reagent (Sigma-Aldrich Chemie, Darmstadt, Germany) transferred to $1.5 \mathrm{~mL}$ disposable cuvettes (Brand $\mathrm{GmbH}$, Wertheim, Germany) and measuring absorbance at $562 \mathrm{~nm}$ with a DR 3900 spectrophotometer (Hach, Düsseldorf, Germany). To determine pore water total Fe concentrations, $150 \mu \mathrm{L}$ of hydroxylamine hydrochloride were added to $800 \mu \mathrm{L}$ of the previous mixture, left to react 10 min to reduce all dissolved $\mathrm{Fe}^{3+}$, stabilized by adding $50 \mu \mathrm{L}$ ammonium acetate and absorbance of the solution measured a second time (Stookey, 1970; Viollier et al., 2000). Pore water total Fe concentrations were found to be the same as $\mathrm{Fe}^{2+}$ concentrations, and thus $\mathrm{Fe}^{3+}$ is essentially absent from pore water. Detection limit of the 
method is $0.25 \mu \mathrm{M} . \mathrm{Mn}^{2+}$ concentrations were analyzed via spectrophotometry using $1 \mathrm{~mL}$ of pore water, as previously published (Jones et al., 2011), following the formaldoxime method (Brewer and Spencer, 1971). Detection limit of the method is $0.02 \mu \mathrm{M}$ (Majestic et al., 2007). Concentrations of $\mathrm{PO}_{4}{ }^{3-}$ in pore water were measured by spectrophotometry. We aliquoted $0.5 \mathrm{~mL}$ pore water to $1.5 \mathrm{~mL}$ disposable cuvettes and added $80 \mu \mathrm{L}$ color reagent consisting of ammonium molybdate containing ascorbic acid and antimony (Murphy and Riley, 1962). Absorbance was measured at $882 \mathrm{~nm}$ via spectrophotometry. Detection limit of the method is $0.05 \mu \mathrm{M}$. Pore water $\mathrm{Na}^{+}, \mathrm{NH}_{4}^{+}$, and $\mathrm{Cl}^{-}$concentrations were analyzed by normal and suppressed ion chromatography with an injected sample volume of $50 \mu \mathrm{L}$, as previously described (Vuillemin et al., 2016). Based on a respective signal-to-noise ratio of 3 and 10, detection and quantification limits of the method calibrated on a multi-element standard are 5.8 and $35.0 \mu \mathrm{M}$ for $\mathrm{Na}^{+}, 11.3$ and $67.6 \mu \mathrm{M}$ for $\mathrm{NH}_{4}{ }^{+}$, and 5.7 and $16.2 \mu \mathrm{M}$ for $\mathrm{Cl}^{-}$. All samples were measured in triplicates, with reproducibility within $<5 \%$. The $\mathrm{pH}$ and alkalinity were measured with a portable $\mathrm{pH}$ meter and colorimetric titration, respectively. Dissolved inorganic carbon (DIC) concentrations were calculated by solving the carbonate system using the $\mathrm{pH}$ and alkalinity profiles and borehole temperatures. The complete pore water dataset, including all major cations and anions (Vuillemin A. et al., 2019b, 2021), was used to calculate mineral saturation indices (Table 1) based on $\mathrm{pH}$, alkalinity, pore water concentrations and borehole temperatures, using the PHREEQC v.3 software (Parkhurst and Appelo, 2013).

Pore water oxygen isotopes were measured via cavity ring-down spectroscopy, using a Picarro L1102-I isotopic water liquid analyzer (Picarro Inc., Santa Clara, United-States) at Brown University, calibrated against the Vienna Standard Mean Ocean Water (VSMOW) with two internal water samples measured every tenth sample to bracket the isotopic composition of the Towuti samples. Results that were initially reported as $\delta$-values in per mil relative to VSMOW were recalculated to the international standard Vienna-Pee Dee Belemnite (V-PDB) (Coplen et al., 1983), applying the oxygen isotope fractionation factor (i.e. $\alpha_{\mathrm{H} 2 \mathrm{O}-\mathrm{sid}}=1.03033$ at $33^{\circ} \mathrm{C}$ ) between water and siderite (Carothers et al., 1988) using temperatures from $28^{\circ}$ to $34^{\circ} \mathrm{C}$ as measured in the borehole TDP-TOW16-1B (Supplementary Fig. S1, Supplementary Table $\mathrm{S} 1)$. As such they allow direct comparison between empirical $\delta^{18} \mathrm{O}$ values measured on siderite crystals and those theoretically expected for siderites forming from modern pore water.

For methane and carbon dioxide analysis, $2 \mathrm{~cm}^{3}$ of sediment were transferred on site inside an anaerobic chamber with a cutoff syringe into a $20 \mathrm{~mL}$ crimp vial, which was completely filled with saturated $\mathrm{NaCl}$ solution and stored at $4^{\circ} \mathrm{C}$. For analysis of dissolved gases, $3 \mathrm{~mL}$ helium $(\mathrm{He})$ was introduced to form a headspace. After 12 hours of equilibration, two aliquots of typically $200 \mu \mathrm{L}$ were taken from the headspace. One was used to determine the partial pressure of methane using a Thermo Finnigan Trace gas chromatograph (Thermo Fisher Scientific, Waltham, United-States) equipped with flame ionization detector 
164 (GC-FID), and the other one was used for carbon isotopic analysis of methane $\left(\delta^{13} \mathrm{CH}_{4}\right)$ and carbon dioxide

$\left(\delta^{13} \mathrm{CO}_{2}\right)$ by isotope-ratio-monitoring gas chromatography/mass spectrometry (irm-GC/MS) on a Trace GC Ultra gas chromatograph (Thermo Fisher Scientific) coupled to a continuous-flow isotope ratio mass spectrometer (Delta V Plus, Thermo Fisher Scientific) as described in Friese et al. (2021). Results are reported as $\delta$-values in per mil relative to V-PDB.

Concentrations of volatile fatty acids (VFAs) in the pore water were measured by 2-dimensional ion chromatography mass spectrometry (2D IC-MS) (Glombitza et al., 2014). Measurements were performed with a Dionex ICS3000 ion chromatograph coupled to a Surveyor MSQ Plus mass spectrometer (both Thermo Fisher Scientific). The first chromatograph dimension separates the VFAs from other inorganic ions by trapping them on a concentrator column and subsequently separating them in the second chromatography dimension. To account for the low salinity of Lake Towuti's pore water (Glombitza et al., 2014), the retention time window of the eluent flow after the first column directed to the concentrator column was shifted by one minute to 3.5 - $8.5 \mathrm{~min}$, compared to the original published method (Glombitza et al., 2014). Prior to analysis, pore water samples were filtered through disposable Acrodisc ${ }^{\circledR} 13 \mathrm{~mm}$ IC syringe filters (pore size $0.2 \mu \mathrm{m}$ ) (Pall Corp., New York, United-States) rinsed with $10 \mathrm{~mL}$ ultrapure Milli-Q ${ }^{\circledR}$ water (Merck KGAA, Darmstadt, Germany) directly before use. The first $0.5 \mathrm{~mL}$ of pore water after filtration was discarded and the second $0.5 \mathrm{~mL}$ used for analysis. Quantification was achieved by a 3-point calibration with external standards containing a mixture of the analyzed VFAs at different concentrations (i.e. 200, 500 and $800 \mu \mathrm{g} \mathrm{L}^{-1}$ ). Blanks of pure Milli- $\mathrm{Q}^{\circledR}$ water were measured to correct for the small background deriving from trace amounts of VFAs accumulating in the trap column. Detection limits for the individual VFAs were all between 0.1 and $0.4 \mu \mathrm{M}$ (i.e. formate: $0.37 \mu \mathrm{M}$, acetate: $0.19 \mu \mathrm{M}$ ).

\section{Sediment geochemical analyses}

Total organic carbon (TOC) concentrations and its carbon isotopic composition were measured on freezedried bulk sediment treated in $20 \mathrm{~mL} \mathrm{5 \%} \mathrm{HCl} \mathrm{at} 50{ }^{\circ} \mathrm{C}$ for 24 hours (Supplementary Fig. S2) as previously described (Vuillemin et al., 2020). Stable carbon isotopes of the bulk OM $\left(\delta^{13} \mathrm{C}_{\text {org }}\right)$ were analyzed from homogenized decalcified samples using an elemental analyzer (EuroVector, EuroEA, Thermo Fisher Scientific) linked to a continuous flow isotope-ratio mass spectrometer (Micromass Isoprime, Elementar $\mathrm{GmbH}$, Langenselbold, Germany). Isotope ratios are reported as $\delta$-values in per mil relative to V-PDB. TOC was back-calculated from the yield of $\mathrm{CO}_{2}$ after sample combustion to dry mass \%. TOC was also determined as the difference between elemental analyzer (Total Carbon) and coulometric (Total Inorganic Carbon) analyses (Russell et al., 2020). Coulometric measurements were carried out at $60^{\circ} \mathrm{C}$ with $\mathrm{H}_{2} \mathrm{SO}_{4}$ and a reaction time of $20 \mathrm{~min}$. Siderite concentrations in bulk sediments were calculated based on mineral carbon values (MinC \%) obtained from previous Rock-Eval analyses (Ordoñez et al., 2019) and corrected according 
to published equations of linear regression (Jiang et al., 2017). Results for siderite concentrations based on coulometric (Russell et al., 2020) and Rock-Eval (Ordoñez et al., 2019) analyses were consistent, with about $20 \%$ siderite in red clays at depth in the sediment succession.

For reactive and total Fe sequential extraction, we processed $200 \mathrm{mg}$ of sediment following the protocol described in Poulton and Canfield (2005). The highly reactive Fe pool is defined as the sum of carbonate-associated Fe (acetate extractable Fe), hydrous Fe (oxyhydr)oxides including ferrihydrite and lepidocrocite ( $0.5 \mathrm{~N} \mathrm{HCl}$ extractable Fe), ferric (oxyhydr)oxides including hematite and goethite (dithionite extractable $\mathrm{Fe}$ ), and magnetite $\left(\mathrm{Fe}^{2+} \mathrm{Fe}_{2}{ }^{3+} \mathrm{O}_{4}\right.$ ) (oxalate extractable $\mathrm{Fe}$ ). These reagents do not extract the Fe present in pyrite $\left(\mathrm{Fe}^{2+} \mathrm{S}_{2}\right)$ (Henkel et al., 2016). The non-reactive Fe pool is defined as Fe contained in silicate minerals after removal of reactive phases (near boiling 6 $\mathrm{N} \mathrm{HCl}$ extractable Fe) (Bauer et al., 2020). Total Fe was obtained by summing up the highly reactive Fe pools and the non-reactive Fe contained in silicate minerals. We acknowledge that sequential extraction procedures may not be fully adapted to tropical soils and derived sediments with high contents of Mn and Fe oxides (Silveira et al., 2006). To fully extract the recalcitrant crystalline fraction, total acid digestions (Leermakers et al., 2019) may be required to avoid potentially underestimating the total Fe content of bulk sediment (Coward et al., 2017). Still, our protocol could dissolve $>92 \%$ of the Fe from the PACS-2 international reference standard, ensuring high Fe yield from the samples. All Fe concentration measurements were performed using a Varian AA875 Flame Atomic Absorption Spectrophotometer (Varian, Palo Alto, United-States). Precision on triplicate measurements was $1.2 \%$ and our limit of detection was $\left.1500 \mu \mathrm{g} \mathrm{g}^{-1}(0.15 \mathrm{wt} \% \text { or } \sim 10 \mu \mathrm{mol} \mathrm{cm})^{-3}\right)$.

\section{Ferrous mineral analyses}

Sampling for analyses of siderite was performed on core catchers and split cores, focusing on 51 intervals with increased siderite concentrations. To separate siderite, vivianite $\left(\mathrm{Fe}_{3}\left[\mathrm{PO}_{4}\right]_{2} \cdot 8 \mathrm{H}_{2} \mathrm{O}\right)$ and magnetic minerals, we performed density separation on $60 \mathrm{~mL}$ of sediment as previously published (Vuillemin et al., 2019a, 2020). Isolated crystals of siderite and vivianite, and magnetic extracts were mounted on $12.7 \mathrm{~mm}-$ diameter aluminum stubs and coated with $15 \mathrm{~nm}$ of gold using a Leica MED 020 BAL-TEC metallizer. Imaging was processed on an Ultra 55 Plus Scanning electron microscope (SEM) (Carl Zeiss SMT, Oberkochen, Germany) equipped with an X-ray Energy Dispersive Spectroscopy (EDS) microanalysis system (UltraDry SDD detector, Thermo Fisher Scientific).

X-ray diffraction (XRD) patterns were obtained for powdered siderites and vivianites extracts using a PANalytical Empyrean X-ray diffractometer (Eindhoven, The Netherlands), operating with a theta-theta goniometer at $40 \mathrm{kV}$ and $40 \mathrm{~mA}$ and a PIXcel 3D detector. CuK $\alpha$ radiation was used with a step size from 4.6 to $85^{\circ}$ theta-theta at 1 min per step. The software packages AXS DIFFRACplus EVA and AXS Topas v. 
4.2 were used to identify minerals and select peak references from the mineralogical database (Supplementary Fig. S3).

Oxygen and carbon isotope analyses of siderites were carried out using an isotope-ratio mass spectrometer (Delta V Advantage, Thermo Fisher Scientific) linked to a Gasbench II (Thermo Fisher Scientific). Siderite crystals were previously separated from bulk sediment applying the density separation described above, and isolated crystals rinsed with deionized water, then with acetone and dried. Although potential OM inclusions in the crystals cannot be fully ruled out, this mineral extraction procedure should ensure minimal contamination with OM (Oehlerich et al., 2013; Lebeau et al., 2014). After automatic flushing of septum-capped boron silicate vials containing the siderite sample in helium atmosphere, 6 to 8 drops of $103 \%$ phosphoric acid were added to $0.26 \pm 0.02 \mathrm{mg}$ carbonate samples and left to react at $70^{\circ} \mathrm{C}$ for at least $48 \mathrm{~h}$, which allows for quantitative digestion at that temperature (Fernandez et al., 2016). Oxygen and carbon isotope ratios are reported as $\delta$-values in per mil. For initial calibration relative to V-PDB certified calcium carbonate standards (NBS18 and NBS19), and a lab-internal reference (Solnhofen limestone) were used to scale-normalize isotope data. The $\delta^{18} \mathrm{O}$ values were corrected with respect to the different acid fractionation factors of calcite and siderite by subtracting $0.97 \%$, which is the difference in phosphoric acid fractionation factors between the systems siderite- $\mathrm{CO}_{2}$ (Rosenbaum and Sheppard, 1986) and calcite- $\mathrm{CO}_{2}$ (Swart et al., 1991) at $70^{\circ} \mathrm{C}$ (Supplementary Table S1). We applied an acid fractionation factor of $\alpha_{\mathrm{CO} 2 \text {-siderite }}=1.00971$ for the reaction temperature of $70^{\circ} \mathrm{C}$ interpolated from data of Rosenbaum and Sheppard (1986). This value is in reasonable agreement with the one reported for sealed vessel digestion at that temperature $\left(\alpha_{\mathrm{CO} 2 \text {-siderite }}=1.01014\right)$ in a more recent study (Fernandez et al., 2016). Applying the Fernandez et al. (2016) equation just produces $0.37 \%$ more negative oxygen isotope ratios (Supplementary Table S2).

Sample preparation and Fe isotope analyses of samples and reference materials were performed at the Helmholtz Laboratory for the Geochemistry of the Earth Surface (HELGES), GFZ Potsdam. For iron isotope analysis, samples (5-10 mg sediment crushed to $<60 \mu \mathrm{M}$ in an agate mortar, $>90 \%$ siderite purity) were treated with $10 \%$ acetic acid for 24 hours at room temperature to dissolve siderite and avoid dissolution of potential silicate impurities (von Blanckenburg et al., 2008). Blanks and reference materials (USGS COQ1 carbonatite, BHVO-2 basalt) were processed in parallel for quality control following published protocols (Schoenberg and von Blanckenburg, 2005; von Blanckenburg et al., 2008) involving separating Fe from all other elements by ion chromatography columns (DOWEX AG-X8 resin) prior to isotope analysis. Purity of sample solutions and quantitative recovery of iron after the column separation procedure was verified by inductively coupled plasma-optical emission spectrometry (ICP-OES, Varian 720ES) analyses. The procedure blanks, measured by quadrupole ICP-MS (Thermo Fischer Scientific iCAP-Qc), contained $<10$ ng $\mathrm{Fe}$, which is less than $0.01 \%$ of process sample Fe and is therefore considered insignificant. Fe isotope 
analysis was performed using a Neptune multi-collector (Thermo Fisher Scientific) inductively coupled plasma mass spectrometer equipped with a Neptune Plus Jet Interface Pump and a quartz-glass spray chamber (double pass cyclon-scott type, Thermo SIS) with a $100 \mu \mathrm{L} \mathrm{min}{ }^{-1}$ self-aspirating PFA nebulizer for sample introduction. Analyses were run in high mass resolution mode $(\mathrm{m} / \Delta \mathrm{m} 5 \%, 95 \%$, ca. 9000) and potential isobaric interferences were monitored and corrected at masses ${ }^{52} \mathrm{Cr}$ and ${ }^{60} \mathrm{Ni}$. For mass bias correction, we used the sample-standard bracketing method with the international reference material IRMM014 as standard. Measurements were repeated 2 to 8 times in two independent sessions, and accuracy was verified by repeated analyses of reference materials (Supplementary Table S3) and comparison to published reference values (Dideriksen et al., 2006; Craddock and Dauphas, 2011; Moeller et al., 2014; He et al., 2015). Isotope ratios $\left({ }^{56} \mathrm{Fe} /{ }^{54} \mathrm{Fe}\right.$ and $\left.{ }^{57} \mathrm{Fe} /{ }^{54} \mathrm{Fe}\right)$ are reported as $\delta$-values in per mil relative to IRMM-014 and are only discussed in terms of $\delta^{56} \mathrm{Fe}$ values.

\section{RESULTS}

\section{Core lithology and bulk sediment}

The seismic profiling (Russell et al., 2016; Ulfers et al., 2021) revealed two major sedimentary units in Lake Towuti. Unit 1 consists of well-stratified sediment that extends from the SWI to a depth of 100 meters below lake floor (mblf). Below 100 mblf, the stratigraphic sequence is essentially composed of shallow lacustrine, fluvial, deltaic and terrestrial sedimentary facies (Unit 2) and is not discussed here. A detailed description of the full stratigraphy is published elsewhere (Russell et al., 2020; Ulfers et al., 2021).

The succession at Site 1 is predominantly fine-grained with clay comprising $60-90 \%$ by volume. The composite sediment record mainly consists of alternating green and red clays, the latter containing variable siderite concentrations (Russell et al., 2016, 2020). Three major lithotypes can be distinguished in Unit 1 based on differences in color, structure, siderite and TOC content: Green clays, red clays, and diatomaceous ooze (Fig. 2A). Green clays are dark, thin to medium bedded, and have generally higher TOC concentrations (Ordoñez et al., 2019). Red clays are thin to medium bedded to mottled, and siderite occurs both finely dispersed in the sediment matrix and in discrete layers, lenses, and concretions (Russell et al., 2020). Laminated to massive diatomaceous oozes are found around 32 and 45 mblf. Vivianites are common between 20 and 50 mblf and mostly found in green clays in co-occurrence of the diatom oozes. Turbidites are relatively rare, but more common from 5 to 20 mblf, and from 55 to $70 \mathrm{mblf}$ (Fig. 2A).

Based on these lithotypes (Fig. 2A), three stratigraphic units were defined along the 100-m-long sediment sequence (i.e. Unit 1a to 1c). From top to bottom, Unit 1a contains low concentrations of ferrous minerals in the sediment (e.g. siderite, vivianite, magnetite) and corresponds with reducing conditions in the water column during the late Holocene. The subsequent interval displays relatively abundant siderite and magnetite in red clays that corresponds to a 10 to 30 m reduction in Lake Towuti's water level (Vogel et al., 
2015) and closed-basin conditions (Costa et al., 2015) during the Late Glacial Maximum (LGM). Unit 1b includes two 5-m thick beds of diatomaceous ooze (Fig. 2A) and vivianites. This interval displays variations in colors from light brown to dark brown with grey-green transitions (Fig. 2B). Vivianite mottles and concretions are also sporadically present in the vicinity of turbidites and tephra between 50 and 70 mblf. The siderites observed in the lower part of Unit $1 \mathrm{~b}$ are much coarser-grained than those observed in Unit 1a. Unit 1c often consists of red clays with coarse-grained siderites, including large mottles and concretions. The very base of Unit 1c consists of a woody peat layer capped by a 1-m thick silt reflecting the transition to the shallow lacustrine, deltaic sedimentary facies composing Unit 2.

The ${ }^{14} \mathrm{C}$ dating results indicate an age of $\sim 44.7 \mathrm{ka}$ at $9.79 \mathrm{mblf}$, whereas those of ${ }^{40} \mathrm{Ar} /{ }^{39} \mathrm{Ar}$ on a tephra at 72.95 mblf yielded an age of $797.3 \pm 1.6 \mathrm{ka}$ (Russell et al., 2020), implying much slower sedimentation rates in stratigraphic Unit 1b and 1c than in Unit 1a (Ulfers et al., 2021; Supplementary Fig. S4). The estimated age of $\sim 1 \mathrm{Ma}$ at the base of the sequence is broadly consistent with molecular clock estimates (Stelbrink et al., 2014) and formation of the Malili Lake basins 1.5 to $2 \mathrm{Ma}$ ago (Watkinson and Hall, 2017). Unit 1a to 1c are interpreted in terms of tectonic evolution of the lake basin, and in particular a gradual increase in accommodation space, and its influence on lake water depth, water column oxygenation, and sediment mineralogy (Russell et al., 2020; Morlock et al., 2021; Sheppard et al., 2021).

Sedimentary OM is mainly autochthonous (Friese et al., 2021), albeit at low concentrations, with some contribution of fluvially-derived material (Morlock et al., 2019; Hasberg et al., 2019). TOC and siderite concentrations display opposite trends, with highest TOC concentrations found in diatom oozes and green clays (Fig. 3A). Siderite concentrations peak in red clays, with concretions becoming more abundant between 60 and 90 mblf. Total Fe concentrations in bulk sediment generally fluctuate between 12 and 15 $\mathrm{wt} \%$ throughout Unit 1a, with a steep increase to $25 \mathrm{wt} \%$ around $5 \mathrm{mblf}$ within the interval corresponding to the LGM (Russell et al., 2014; Costa et al., 2015). Total Fe concentrations are highest from 50 to 60 mblf, where turbidites are also more frequent. Reactive Fe concentrations vary between 5 and $15 \mathrm{wt} \%$ and are consistent with total Fe throughout the sequence. Intervals of increased deposition of reactive Fe occur at 5 and 60 mblf (Fig. 3A).

\section{Pore water geochemistry}

$\mathrm{Cl}^{-}$concentrations in pore water display an increase from 53 to $136 \mu \mathrm{M}$ around $8 \mathrm{mblf}$, and fluctuate between 60 and $200 \mu \mathrm{M}$ below, with generally higher values in the bottom core (Fig. 3B). In contrast, $\mathrm{Na}^{+}$ concentrations display a steep increase from $115 \mu \mathrm{M}$ at the SWI to $400 \mu \mathrm{M}$ around $8 \mathrm{mblf}$. Concentrations then regularly increase from $400 \mu \mathrm{M}$ at $12 \mathrm{mblf}$ to $1000 \mu \mathrm{M}$ in the lowermost part of the core. The increase in $\mathrm{Cl}^{-}$and $\mathrm{Na}^{-}$concentrations roughly coincides with sediment deposited during the lake level drop during the LGM (Vogel et al., 2015; Costa et al., 2015). Concentrations of pore water $\mathrm{Fe}^{2+}$ are highly variable 
throughout the sedimentary sequence $(17-278 \mu \mathrm{M})$. Some of the intervals with highest dissolved $\mathrm{Fe}^{2+}$ values are found in the uppermost part of the record (1-4 mblf), around $15 \mathrm{mblf}$, and in bottom core sediment. In comparison, $\mathrm{Mn}^{2+}$ concentrations are much lower, displaying a single increase from 0.5 to $20 \mu \mathrm{M}$ between 10 and 20 mblf, and rapidly decrease reaching our detection limit $(0.02 \mu \mathrm{M})$ at $60 \mathrm{mblf}$. This $10-\mathrm{m}$-long interval displaying high $\mathrm{Mn}^{2+}$ and $\mathrm{Fe}^{2+}$ concentrations mostly consists of green clay (Fig. 3B).

Pore water $\mathrm{PO}_{4}{ }^{3-}$ concentrations increase from zero at the SWI to $0.62 \mu \mathrm{M}$ at 7 mblf. Below this depth, concentrations decrease and remain low $(<0.4 \mu \mathrm{M})$, with slightly higher values in sediment right above the peat layer. Pore water $\mathrm{NH}_{4}{ }^{+}$concentrations increase gradually from $20 \mu \mathrm{M}$ at the SWI to $68 \mu \mathrm{M}$ at 1 mblf, reaching $161 \mu \mathrm{M}$ at 6 mblf. Below this depth, values decrease to about $80 \mu \mathrm{M}$ and fluctuate. Formate concentrations in pore water increase rapidly in near-surface sediment, reaching $30 \mu \mathrm{M}$ at $0.8 \mathrm{mblf}$. Below this depth, values drop to $5 \mu \mathrm{M}$ and fluctuate between 7 and $14 \mu \mathrm{M}$ in the remainder of the core (Fig. 3B). Pore water acetate concentrations vary within the upper $1 \mathrm{mblf}$, where they initially increase from $10 \mu \mathrm{M}$ to their maximal value of $38 \mu \mathrm{M}$ at $5 \mathrm{mblf}$, then decrease to $10 \mu \mathrm{M}$ at $20 \mathrm{mblf}$ and fluctuate below. These different profiles are consistent with active processes of OM mineralization within the upper 20 mblf (Friese et al., 2021) and stepwise fermentation of labile substrates (Vuillemin et al., 2014a).

The temperature profile obtained on site via borehole logging (Ulfers et al., 2021) shows an overall increase from $28^{\circ}$ to $33^{\circ} \mathrm{C}$ in the $100 \mathrm{~m}$ of Unit 1 (Supplementary Fig. S1). The pH of pore water increases from 6.8 in surface sediment to 7.6 at 8 mblf, and then oscillates between 7.0 and 7.5 down core (Fig. 5A). The highest $\mathrm{pH}$ values (i.e. 8.2 to 8.5 ) are found in sediment above the peat layer. Alkalinity [meq $\left.\times \mathrm{L}^{-1}\right]$ in pore water constantly increases down core from 2.0 to 7.6 (Supplementary Fig. S1). Based on the previous two profiles, DIC was calculated by solving the carbonate system. At pH between 6.8 and 8.5 and with increasing alkalinity, DIC accumulates in the pore water, mainly in the form of $\mathrm{HCO}_{3}{ }^{-}($Supplementary Fig. S1).

Within the upper 20 mblf, both pore water DIC and methane concentrations consistently increase gradually from 2 to $5 \mathrm{mM}$ with depth (Fig. 3B). Below this depth, DIC increases gradually, reaching $6 \mathrm{mM}$ at the bottom of the core, whereas methane concentrations fluctuate between $5 \mathrm{mM}$ and $1 \mathrm{mM}$ in green and red clays, respectively (Fig. 3B). Although potential depressurization during core retrieval could result in scattered values around $3 \mathrm{mM}$ reflecting the solubility of methane under atmospheric pressure, this does not influence the $\delta^{13} \mathrm{C}$ compositions of gases.

\section{Temperature, $\mathrm{pH}$ and isotope compositions of the water column}

Lake Towuti's water column is weakly thermally stratified (i.e. $31-28^{\circ} \mathrm{C}$ ), circumneutral (pH 8.4 to 7.2)

(Bauer et al., 2020), and presently oxygen-depleted below $130 \mathrm{~m}$ depth (Figs. $1 \mathrm{C}$, and $5 \mathrm{~A}$ ). The $\delta^{18} \mathrm{O}$ values 
measured over the $200 \mathrm{~m}$ of the water column display a variation of $0.5 \%$ against VSMOW, with a temperature decrease of $2.5^{\circ} \mathrm{C}$ from the lake surface (i.e. $-5.08 \%$, $30.5^{\circ} \mathrm{C}$ ) down to the SWI (i.e. $-4.64 \%$, $28^{\circ} \mathrm{C}$ ). The most positive $\delta^{18} \mathrm{O}$ value (i.e. $-4.15 \%$ ) is found in the oxycline (Fig. 5B, Supplementary Fig. S5). By analogy with nearby Lake Matano (Kuntz et al., 2015), the $\delta^{13} \mathrm{C}$ values expected for Lake Towuti's water column show that values tend to be ${ }^{13} \mathrm{C}$-enriched at higher $\mathrm{pH}$ in surface waters (i.e. $-6.5 \%$, $\mathrm{pH} 8.4$ ) and depleted in the heavy isotope at lower $\mathrm{pH}$ in anoxic bottom waters (i.e. $-7.7 \%$, $\mathrm{pH}: 7.3$ ). The $\delta^{13} \mathrm{C}$ values also tend to decrease in the vicinity of the oxycline (i.e.-8.0 to $-7.9 \%$ ).

\section{Isotope compositions in the sediment}

The $\delta^{13} \mathrm{C}$ values of the bulk OM are mostly around -30 to $-33 \%$ throughout the sequence (Fig. 3C). An exception is the interval between 4 and 10 mblf, which was previously reported to correspond to the LGM (Russell et al., 2014; Costa et al., 2015). There, an important increase to the most ${ }^{13} \mathrm{C}$-enriched values ($21.2 \%$ ) of the record occurs. The most ${ }^{13} \mathrm{C}$-depleted values are observed in the vicinity of the diatomaceous oozes ( -32.7 to $-33.8 \%$ ), with two subsequent increases to -27.0 and $-27.4 \%$ at 50 and $60 \mathrm{mblf}$, respectively. The $\delta^{13} \mathrm{C}$ values of methane are $-72.7 \%$ in uppermost sediment and increase to $-66.3 \%$ at $25 \mathrm{mblf}$, depth after which they remain constant throughout the sediment sequence (Fig. 3C). These values are well in the range indicative of biogenic methane (Penger et al., 2012; Lecher et al., 2017). The $\delta^{13} \mathrm{C}$ values of DIC increase in parallel to those of methane, from $-14.5 \%$ in the uppermost sediment to $-13.2 \%$ at 10 mblf, and remain constant throughout the remainder of the core (Figs. 4A-5B). These $\delta^{13} \mathrm{C}$ values for methane and DIC are consistent with the consumption of $\mathrm{CO}_{2}$ by hydrogenotrophic methanogens (Lecher et al., 2017; Friese et al., 2021) and mass balance during OM remineralization (Boehme et al., 1996).

The $\delta^{13} \mathrm{C}$ values measured in siderite (Fig. 4A) highly fluctuate within the upper $20 \mathrm{mblf}$, varying from $-15.8 \%$ to close to $-0.7 \%$ around 10 mblf. From 20 to 80 mblf, values scatter around -13\%o (i.e. -10.1 to $-14.5 \%$ ), the minimal $\delta^{13} \mathrm{C}$ value $(-16.4 \%$ ) being at 53 mblf, but mostly remain in the same range as those measured on DIC. From 80 to 100 mblf, values quickly increase to about $3.8 \%$ in the sediment overlying the peat horizon.

The modeled $\delta^{18} \mathrm{O}$ values of siderite (Fig. 4A) calculated from pore water oxygen isotopes (Fig. 5B) display minor variations around an average of $-5.5 \%$ down core (Figs. 4A and 5C). In contrast, those actually measured in siderite crystals display considerable variations within the upper 20 mblf, with an initial increase from $-4.5 \%$ in surficial sediments to $-1.3 \%$ at 7 mblf, near the LGM interval, and a subsequent decrease to about $-7.2 \%$ between 12 and 18 mblf in green clay. Below $20 \mathrm{mblf}$ and throughout the lowermost part of the core, $\delta^{18} \mathrm{O}$ values fluctuate around $-5 \%$, with two excursions (-3.3 and $-3.4 \%$ ) between 65 and 85 mblf (Figs. 4A and 5C). 

along sediment depth (Fig. 4A). In Unit 1a, values decrease from $-0.2 \%$ in surface sediment to $-0.6 \%$ at 10 mblf, then increase to $-0.3 \%$ at 20 mblf, depth under which they co-vary with pore water $\mathrm{Fe}^{2+}$ and $\mathrm{Mn}^{2+}$ concentrations (Fig. 3B). The transition to Unit $1 \mathrm{~b}$ is marked by the apparition and sporadic occurrence of vivianites (Fig. 2B) (Russell et al., 2020; Vuillemin et al., 2020), whose $\delta^{56}$ Fe values are in between -0.4 and $-0.6 \%$. Minima for siderites are found around 55 and 70 mblf, whereas deeper in Unit 1c values are almost constant between -0.2 and $-0.3 \%$. Overall, the $\delta^{56} \mathrm{Fe}$ profile obtained for both siderites and vivianites display four minima located in green clays around 10, 30, 50 and 70 mblf (Fig. 4A).

\section{Mineral analyses and imaging}

The SEM images document the existence and formation of diverse $\mathrm{Fe}^{2+}$-bearing phases (Fig. 6). SEM images reveal different habits for magnetite, such as framboids, nm-sized flake aggregates and highly dissolved residual crystals (Fig. 6A). Pelagic framboidal magnetites were previously observed in sediment traps in concomitance with 5 to $10 \mu \mathrm{M}$ euhedral monocrystals that were considered detrital in origin (Bauer et al., 2020). In deeper sediments, sources of magnetite are also multiple (e.g. detrital, volcanic, microbial precipitates) and display features of dissolution and precipitation that cannot be considered unequivocal biosignatures (Supplementary Fig. S6), but show that magnetite is exposed to reductive dissolution during burial (Tamuntuan et al., 2015). EDS analysis on magnetic extracts (Supplementary Table S4) reveals the incorporation of trace elements (i.e. $\mathrm{Cr}, \mathrm{Ti}, \mathrm{Ni}, \mathrm{Mn}$ ) reflecting the likely presence of detrital phases derived from the ultramafic catchment (Fig. 6A), such as chromite $\left(\mathrm{Fe}^{2+} \mathrm{Fe}_{2}{ }^{3+} \mathrm{O}_{4}\right)$, wüstite $\left(\mathrm{Fe}^{2+} \mathrm{O}\right)$ and ulvöspinel $\left(\mathrm{Fe}_{2}{ }^{2+} \mathrm{Ti}^{4+} \mathrm{O}_{4}\right)$, whereas an increasing content of $\mathrm{Ni}^{2+}$ and $\mathrm{Mn}^{2+}$ could possibly reflect authigenic formation of magnetite in the water column and sediment (Vuillemin et al., 2019a; Bauer et al., 2020).

SEM images from increasingly deep sediment samples show that siderites initially develop from micritic phases into mosaic crystals in the upper 15 mblf (Fig. 6B). With depth of burial, siderite forms and grows into stubby crystal morphologies, merging into large mosaic-type crystals through twinning and aggregation during diagenetic maturation (Vuillemin et al., 2019a). The siderites from deep sediments display denser aggregates and have little remaining pore space in contrast to those from surficial sediments that are smaller and porous (Supplementary Fig. S7). EDS analyses on siderites (Supplementary Table S5) show quantitative substitution of $\mathrm{Fe}^{2+}$ by $\mathrm{Mn}^{2+}$ in samples (Fig. 6B) from relatively shallow depths $(<15$ mblf), thereby revealing the presence of Mn-rich early growth phases or nuclei (Supplementary Fig. S7). Deeper samples show compositions that are close to the chemical formula of siderite, with limited substitution of $\mathrm{Fe}^{2+}$ by $\mathrm{Ca}^{2+}$ and $\mathrm{Mg}^{2+}$.

SEM images of vivianite crystals show that this mineral grows from a tabular habit to rosette with the addition of blades around an initial central tabular template (Fig. 6C). EDS analyses (Supplementary Table 
426 S6) indicate that quantitative incorporation of $\mathrm{Mn}^{2+}$ occurs in early crystals of vivianite that likely enclose 427 iron oxides during continuous crystal growth with depth of burial (Vuillemin et al., 2020).

\section{DISCUSSION}

429 Combined O-Fe-C isotope measurements in siderite have been used to assess syn-depositional and post430 depositional reactions that affect the rock and sediment record of ferruginous basins (Hangari et al., 1980; 431 Heimann et al., 2010). These isotope compositions are taken as direct indicators of past aquatic conditions 432 (Poulton et al., 2004; Klein, 2005; Holland, 2006), elseways early authigenic mineral formation and soft 433 sediment diagenesis are thought to control the isotopic signatures of siderite (Raiswell et al., 2011; Johnson 434 et al., 2013; Posth et al., 2014).

For instance, the $\delta^{18} \mathrm{O}$ variations in authigenic carbonates can record changes in salinity (Liu et al., 2009), temperature (Leng and Marshall, 2004) and water isotopic composition (Oehlerich et al., 2015). In lacustrine systems, the latter is largely controlled by water balance, i.e. the interplay between lake inflow and evaporation (Lamb et al., 2006; Mayr et al., 2007). However, microbially-mediated diagenetic processes also result in oxygen isotope fractionation towards lower $\delta^{18} \mathrm{O}$ values in carbonates, potentially due to organic carbon remineralization (Hangari et al., 1980; Heimann et al., 2010) and precipitation in disequilibrium ((Fronval et al., 1995; Watkins et al., 2013) that may overprint water column signals (Mortimer and Coleman, 1997; Teranes et al., 1999; Kuntz et al., 2015).

Iron isotopes act as tracers of abiotic and microbially-mediated redox processes in aquatic systems and anoxic sediments (Busigny et al., 2014; McCoy et al., 2016). During abiotic oxidation at redox interfaces, equilibrium fractionation between aqueous $\mathrm{Fe}^{2+}$ and precipitated $\mathrm{Fe}^{3+}$ in ferruginous systems can amount to $3 \%$. In contrast, kinetic Fe isotope fractionation (i.e. preferential precipitation of ${ }^{54} \mathrm{Fe}$ relative to ${ }^{56} \mathrm{Fe}$ ) during microbial reduction releases $\mathrm{Fe}^{2+}$ with $\delta^{56} \mathrm{Fe}$ values up to $2 \%$ lower than the original ferric substrates (Icopini et al., 2004; Wiesli et al., 2004). Mixing of anoxic bottom waters and sediment early 450 diagenesis can result in ferrous minerals with $\delta^{56} \mathrm{Fe}$ values between -0.8 and $-0.2 \%$ lower than those of igneous rocks (Staubwasser et al., 2006; Tangalos et al., 2010). These are $\delta^{56}$ Fe values one can initially expect of Towuti's ultramafic catchment and related detrital sources $\left(\delta^{56} \mathrm{Fe}=+0.1 \pm 0.1 \%\right.$ ). These effects water column are buried and reduced in the anoxic sediment. As pore water becomes gradually saturated with dissolved $\mathrm{Fe}^{2+}$ (Jiang and Tosca, 2019), ferrous mineral phases start precipitating during early 456 diagenesis (Severmann et al., 2006), which may compromise the preservation of the original environmental signatures from the time of deposition (Posth et al., 2014). 
Finally, the carbon isotope record from iron carbonates has been used to infer primary productivity (Lyons et al., 2014), rates of OM burial (Bachan and Kump, 2015) and oxidation (Kump et al., 2011) across the Precambrian Eons (Saltzman and Thomas, 2012). It can also be used to inform on geochemical conditions at the time of deposition (Raiswell et al., 2011; Wittkop et al., 2014), OM diagenetic pathways (Johnson et al., 2013) and post-depositional alteration of siderite phases (Ohmoto et al., 2004). In contrast, microbial respiration of OM with ferric iron in near-surface soft ferruginous sediment (Friese et al., 2021) can rapidly lead to pore water enrichment with biogenic $\mathrm{HCO}_{3}{ }^{-}$and aqueous $\mathrm{Fe}^{2+}$, thereby reaching saturation with respect to siderite prior to lithification (Mortimer et al., 1997; Vuillemin et al., 2019a). Because post-depositional growth of siderite crystals incorporates biogenic DIC from pore water, low $\delta^{13} \mathrm{C}$ values (ca. $-15 \%$ ) reflect ${ }^{12} \mathrm{CO}_{2}$ production by non-methanogenic fermentative bacteria (Kump et al., 2011).

Here, we discuss individual and combined isotopic signatures of siderites in the context of Lake Towuti's geological evolution and related processes covering $~ 1$ Ma of depositional and diagenetic history and conclude on the use of siderite as an indicator for the ancient rock record.

\section{Oxygen isotopes: Past hydrological conditions and pore water influences}

Most siderites in Lake Towuti's upper $20 \mathrm{~m}$ of sediment carry $\delta^{18} \mathrm{O}$ values that strongly differ from those calculated from the pore water (Figs. 4A and 5C), implying that these $\delta^{18} \mathrm{O}$ signatures could be inherited from variations in isotopic composition or temperature of the paleolake bottom waters. The $\delta^{18} \mathrm{O}$ values measured in the modern water column appear negatively correlated with its temperature variations, suggesting that a $2.5^{\circ} \mathrm{C}$ cooling of bottom water results in water isotope composition that is $0.5 \%$ heavier than at the lake surface (Figs. 5A-5B). Molecular diffusion across the SWI implies that early siderite crystals (i.e. nuclei) grow and incorporate oxygen isotopes from pore water in equilibrium with bottom water isotopic compositions. Diffusion in lacustrine fine sediments usually reaches down to 0.7 to $1 \mathrm{mblf}$ (Hesslein, 1980). Such sediment depth is consistent with the onset of carbonate mineral precipitation in the $\mathrm{Fe}^{3+}$ reductive zone (Furrer and Wehrli, 1996) which, in Lake Towuti, is restricted to the uppermost ferruginous sediment (Bauer et al., 2020) while still extending at very low reduction rates down to 4 mblf (Friese et al., 2021). A sedimentation rate of $21.9 \mathrm{~cm} \mathrm{ka}^{-1}$ in the upper $1 \mathrm{mblf}$, documented by radiocarbon dating (Russell et al., 2014, 2020), implies that bottom and pore waters remain in isotopic equilibrium for about $4.5 \mathrm{ka}$ after sediment deposition, but that oxygen isotopes equilibrate over longer time, potentially due to diffusion by Brownian motion (Islam, 2004). In addition, ferruginous sediments are noticeably denser than siliciclastic sediments, which may result in higher compaction rates (Bjørlykke, 2015). This would further imply that early diagenetic processes relevant to shallow formation of siderite (Carrigan and Cameron, 1991) occur prior to the loss of pore water and related increase in dry-bulk density (Maier et al., 2013). 
From surface sediment down to $10 \mathrm{mblf}$ (Figs. 4A and $5 \mathrm{C}$ ), siderite $\delta^{18} \mathrm{O}$ values $(-4.4$ to $-1.3 \%$ ) are

491

492

493

494

495

496

497

498

499

500

501

502

503

504

505

506

507

508

509

510

511

512

513

514

515

516

517

518

519

520

521

522 higher than those calculated from pore water $\delta^{18} \mathrm{O}$ compositions (-5.4 to $-6.2 \%$ ). These relatively ${ }^{18} \mathrm{O}-$ enriched values coincide with higher $\delta^{13} \mathrm{C}$ values in organic carbon (Fig. 3C) representing increased contributions from in $\mathrm{C}_{4}$ grasses to the bulk OM (Russell et al., 2014; Wicaksono et al., 2015). During the LGM, an important lake level drop with hydrological closure (Vogel et al., 2015; Russell et al., 2014; Costa et al., 2015) contributed to evaporative ${ }^{18} \mathrm{O}$-enrichment of Lake Towuti's water body. Although temperaturedependent fractionation has also been reported to account for the difference between modeled and measured $\delta^{18} \mathrm{O}$ values in biogenic siderites (Zhang et al., 2001), it is uncertain whether past atmospheric variations and regional cooling (Leng et al., 2006) could have affected the lake's bottom water temperatures and ${ }^{18} \mathrm{O}$ compositions during the LGM. Modern Lake Towuti is an open basin with a short residence time losing about $70 \%$ of water inputs through its outflow (i.e. Larona River). Ambient humidity is high, suppressing evaporation. Moreover, temperatures in the sediment increase down hole, with little variation in pore water $\delta^{18} \mathrm{O}$ values (Figs. 5A-5B, Supplementary Fig. S1). Based on isotopic temperature scale (van Dijk et al., 2018) and water column profiles in modern Lake Towuti (Figs. 5A-5B), bottom waters would have to be $11.5^{\circ} \mathrm{C}$ cooler than today to account for the $2.52 \%$ increase in $\delta^{18} \mathrm{O}$ values measured in siderites (Fig. 5C), assuming that the $\delta^{18} \mathrm{O}$ signal is attributed to temperature changes only. This would equal temperatures around $16^{\circ} \mathrm{C}$ in bottom waters during the LGM. Regional climate reconstructions for Sulawesi (Dam et al., 2001; Russell et al., 2014) report a wet climate ca. 35 ka ago, but dry conditions from 31 to 13 ka (Hope et al., 2001) followed by a moistening trend from the late glacial into the Holocene (Tierney et al., 2012). The monsoon seasonality on Sulawesi (Wicaksono et al., 2015; Russell et al., 2020) further highlights the importance of evaporative enrichment to match the observed isotopic compositions (Fig. 5B). From November to May, the northeast monsoon delivers strong ${ }^{18}$ O-depleted rainfall (-10 to-7\%o) on Sulawesi, whereas reduced precipitation of the southwest monsoon during summer is isotopically heavier (-4 to $-6 \%$ ) (Konecky et al., 2016). Thus, higher $\delta^{18} \mathrm{O}$ values could signify decreased rainfall with a higher evaporationto-inflow ratio (Mayr et al., 2007; Li et al., 2020), and further suggest that oxygen isotopes in siderites recorded hydrological conditions related to a closed basin with diminished northeast precipitations during the LGM. The present range of $\delta^{18} \mathrm{O}$ values is similar to those reported for ancient and modern pedogenic siderites that recorded oxygen isotopic composition of past precipitations and groundwater (Driese et al., 2010; Ludvigson et al., 2013). In addition, $\mathrm{Cl}^{-}$concentrations in pore water, considered a reflection of paleolake salinities (Vuillemin et al., 2014b), are consistent with increased evaporation in Lake Towuti during that period while excluding potential recharge with modern lake waters (Fig. 3B). The contrasting increase in $\mathrm{Na}^{+}$concentrations with depth was interpreted as a result of clay alteration during diagenesis (Curtis, 1985). 
From 10 to $20 \mathrm{mblf}, \delta^{18} \mathrm{O}$ values in siderites are the most negative of the profile (-7.2 to $-6.9 \%$ ),

524

525

526

527

528

529

530

531

532

533

534

535

536

537

538

539

540

541

542

543

544

545

546

547

548

549

550

551

552

553

554

555

which represents an interval of green clay corresponding with presumably much wetter conditions some 60 ka ago and likely a higher lake level (Russell et al., 2014). By analogy with the $\delta^{18} \mathrm{O}$ values measured in permanently stratified nearby Lake Matano (Katsev et al., 2010), an explanation would be an inflow-toevaporation ratio greater than today leading to a lake-level highstand with long-term stratification of the water column (Fig. 4B). Siderites forming in equilibrium with the present-day monimolimnion waters of Lake Matano (-6.5 to $-7.0 \%$ to VSMOW) would theoretically show siderite $\delta^{18} \mathrm{O}$ values around $-7.5 \%$ (VPDB), similar to our observations in Lake Towuti's sediment during this interval (Carothers et al., 1988; van Dijk et al., 2018). Under permanently stratified conditions, methane production also occurs in Lake Matano's anoxic waters (Kuntz et al., 2015), suggesting that organic carbon remineralization and related changes in $\mathrm{pH}$ and DIC could promote disequilibrium precipitation (Fronval et al., 1995; Watkins et al., 2013) and influence the water column $\delta^{18} \mathrm{O}$ signals (Hangari et al., 1980; Teranes et al., 1999; Heimann et al., 2010). Another effect of long-term stratification in Lake Matano is the accumulation of dissolved $\mathrm{Fe}^{2+}$ and $\mathrm{Mn}^{2+}$ in anoxic bottom waters (Crowe et al., 2008a; Katsev et al., 2010; Jones et al., 2011; Bauer et al., 2020), which could further result in increased $\mathrm{Fe}^{2+}$ and $\mathrm{Mn}^{2+}$ concentrations in pore water after burial, as it is presently observed for Lake Towuti in this sediment interval (Fig. 3B). From 20 to 60 mblf (Unit 1b), the siderite $\delta^{18} \mathrm{O}$ values in Lake Towuti are also in better agreement with those calculated from pore waters (Figs. 4A and 5C). In the lowermost sediments (Unit 1c), variable hydrological conditions during the initial basin filling of Lake Towuti (Russell et al., 2020; Morlock et al., 2021) produced siderites with $\delta^{18} \mathrm{O}$ values fluctuating between -6.1 and $-3.3 \%$. This sediment sequence also corresponds with an overall lower lake level, perhaps with a smaller drainage basin (Fig. 7), related to the gradual tectonic and geomorphic formation of the lake (Watkinson and Hall, 2017; Russell et al., 2020).

Our $\delta^{18} \mathrm{O}$ measurements thus support previous lithostratigraphic observations, and suggest that Lake Towuti alternated between hydrologically open and closed configurations throughout its history. Our $\delta^{18} \mathrm{O}$ analyses also confirm that siderites commonly form in surficial sediment under oxidizing depositional conditions that promote burial of reactive ferric iron (Vuillemin et al., 2019a, 2020). Oxidizing conditions at the SWI could either result from a regionally drier climate at Lake Towuti, with shorter monsoon and evaporative cooling of the lake inducing water column mixing and/or lower lake levels (Costa et al., 2015; Russell et al., 2020). Alternatively, erosion of the lateritic catchment during wetter periods and sporadic turbiditic events likely increased lithogenic inputs of ferric iron to the lake deep basin (Tamuntuan et al., 2015; Vogel et al., 2015; Morlock et al., 2019).

Altogether, siderites may initially record a signal arising from hydrological conditions, but OM remineralization in the sediment increases pore water DIC and, thereby, maintains saturation with respect to 
siderite (Table 1). Siderite overgrowth on nuclei incorporates pore water isotopes and results in relatively constant $\delta^{18} \mathrm{O}$ values during diagenesis. We infer limited diagenetic maturation of siderite crystals in Unit 1a as siderite nuclei inherit the isotopic composition of past hydrological conditions and bottom waters during formation in surficial sediment, whereas, in Unit $1 \mathrm{~b}$ and 1c, the mass added to growing crystals (Fig. 6B) may dominate the siderite nuclei's isotope signals (Mortimer et al., 1997; Vuillemin et al., 2019a). We hypothesize that the volume ratio of rims to nuclei (Supplementary Fig. S5) follows a mass balance, during which precipitating most of the siderite from saturated pore water would align their respective $\delta^{18} \mathrm{O}$ values (Figs. 4A and 5C) and mute the environmental signature through long-term reaction with average pore water during burial.

\section{Iron isotopes: Sources, water column stratification and reductive diagenesis}

In Lake Towuti, detrital minerals derived from lateritic soils (Hasberg et al., 2019; Morlock et al., 2019) and primary Fe-oxides formed at the oxycline (Bauer et al., 2020) experience reductive dissolution in the water column and surficial sediment (Tamuntuan et al., 2015; Sheppard et al., 2019, 2021). Continuous removal of one phase at the oxycline (i.e. Rayleigh processes) results in ferric iron precipitates that may display $\delta^{56} \mathrm{Fe}$ values up to 1-2\%o higher than the remaining aqueous $\mathrm{Fe}^{2+}$ (Bullen et al., 2001; Anbar, 2004; Wiesli et al., 2004). On the contrary, mixing of anoxic bottom waters can produce ferric minerals with $\delta^{56} \mathrm{Fe}$ values between -0.8 and $-0.2 \%$ lower than their detrital sources (Staubwasser et al., 2006; Tangalos et al., 2010). Thus, depositional fluxes in anoxic bottom waters have the potential to form isotopically light $\mathrm{Fe}^{3+}$ nanocrystalline phases (i.e. ferrihydrite-like phases) that precipitate in the sediment (Bullen et al., 2001; Severmann et al., 2008) as microbially reducible ferric iron (Crowe et al., 2007; Bray et al., 2017). The isotope fractionation takes place by either partially oxidizing the isotopically light $\mathrm{Fe}^{2+}$ dissolved in bottom waters or by extracting the isotopically heavy $\mathrm{Fe}^{3+}$ into magnetite (Bauer et al., 2018, 2020). Because Lake Towuti's sediments are depleted of highly reactive ferric phases (Fig. 3A) after only shallow depths of burial (Bauer et al., 2020; Friese et al., 2021), the $\delta^{56} \mathrm{Fe}$ signatures of siderites are expected to reflect isotope variability between detrital and pelagic ferrihydrite-like phases (Severmann et al., 2008; Wu et al., 2019, references therein) and $\mathrm{Fe}^{2+}$ partitioning in equilibrium with pore water (Severmann et al., 2006). During early diagenesis, different ferrous phases can precipitate (Table 1) according to geochemical evolution of pore water (Staubwasser et al., 2006; Posth et al., 2014; Planavsky and Busigny, 2017; Vuillemin et al., 2020).

The investigated 100-m-long sedimentary sequence consists largely of alternating dark green to reddish-grey clays (Fig. 2A). SEM images document the existence and progressive growth of different diagenetic ferrous phases, including siderite, during burial (Figs. 6A-6C). In the absence of pyrite (sulfate $<$ $20 \mu \mathrm{M}$ ) and only minor magnetite formation in Lake Towuti (Vuillemin et al., 2019a; Bauer et al., 2020), 
589

590

591

592

593

594

595

596

597

598

599

600

601

602

603

604

605

606

607

608

609

610

611

612

613

614

615

616

617

618

619

620

621

622

siderites and vivianites are the main $\mathrm{Fe}^{2+}$-bearing minerals to form (Figs. 6B-6C) which are mostly found in reddish and green clay, respectively. Although reddish clays contain evidence for oxidizing lacustrine conditions, they also contain abundant ferrous minerals relating to both pre- and post-depositional redox processes (Tamuntuan et al., 2015; Russell et al., 2020; Sheppard et al., 2021). In the upper $10 \mathrm{~m}$ of Unit 1a, pore water $\mathrm{Fe}^{2+}$ concentrations rapidly increase below the SWI and drastically drop while $\delta^{56} \mathrm{Fe}$ values in siderites decrease from -0.2 to $-0.6 \%$ (Figs. 3B and 4A). Since microbial Fe reduction is mostly active in the uppermost sediment (Bauer et al., 2020; Friese et al., 2021), this suggests kinetic Fe isotope fractionation followed by rapid and continuous incorporation of dissolved $\mathrm{Fe}^{2+}$ in siderites as pore water becomes saturated with DIC (Fig. 3B; Table 1). Pore water concentrations of formate, acetate, methane, $\mathrm{NH}_{4}{ }^{+}$and $\mathrm{PO}_{4}{ }^{3-}$ successively peak in sediment from 1 to $10 \mathrm{mblf}$ (Fig. 3B). As the main products of OM mineralization, these pore water constituents demonstrate that biogenic DIC is actively produced during fermentation processes subsequent to Fe reduction. Ongoing OM fermentation further drives a gradual increase in alkalinity and raises the $\mathrm{pH}$ of pore water (Fig. 5A; Supplementary Fig. S1) resulting in steady siderite saturation (Table 1). Consistent with metal concentrations in surficial pore water (Fig. 3B), SEM elemental analyses show that siderites initially precipitate as Mn-rich nuclei and further develop in twins and aggregates during burial (Fig. 6B; Supplementary Fig. S7).

Transiting from Unit 1a to Unit 1b, sideritic beds are less common from 20 to 50 mblf, whereas vivianites are increasingly found from 20 to 70 mblf (Figs. 2A-2B). The first occurrence of vivianites coincides with a drastic decrease in pore water $\mathrm{Mn}^{2+}, \mathrm{Fe}^{2+}$ and $\mathrm{PO}_{4}{ }^{3-}$ concentrations (Fig. 3B), providing evidence for vivianite nucleation around $20 \mathrm{mblf}$ (Vuillemin et al., 2020). The occurrence of vivianite crystals further questions redox conditions in Lake Towuti's bottom waters at the time of deposition as oxicanoxic transitions during periods of lake stratification provide the right conditions to form ferric phosphate precursors (Vuillemin et al., 2013; Heinrich et al., 2020). Moreover, the corresponding sediments display variations in colors (Fig. 2B) that we presently interpret as reflecting redox conditions at the SWI (Fig. 7). This vivianite-bearing interval coincides with high productivity of diatoms and likely diffusion of dissolved phosphate and ferrous iron across the SWI and their recycling in the lake (Russell et al., 2020; Vuillemin et al., 2020). In the sediment when sufficient $\mathrm{PO}_{4}{ }^{3-}$ is made available through microbial processes of OM degradation, and also sporadic tephra inputs (Russell et al., 2020; Vuillemin et al., 2020), vivianite can nucleate and thereby act as an additional sink for the light $\mathrm{Fe}^{2+}$ isotope, exhibiting $\delta^{56} \mathrm{Fe}$ values as low as 0.6\% (Fig. 4A). Along this interval, vivianite crystals develop from a tabular habit into rosette (Fig. 6C), with mottles and concretions between 40 and 70 mblf, indicating continued growth of vivianite at the expense of siderite after formation and during burial.

Below 70 mblf (Unit 1c), siderite $\delta^{56} \mathrm{Fe}$ values increase in concomitance with pore water $\mathrm{Fe}^{2+}$ concentrations. On the one hand during Lake Towuti's initial stage, subsidence exceeded sediment 
623

624

625

626

627

628

629

630

631

632

633

634

635

636

637

638

639

640

641

642

643

644

645

646

647

648

649

650

651

652

653

654

655

deposition (Fig. 7) due to active bounding between the Matano and Lawanopo normal faults (Watkinson and Hall, 2017). Rapid subsidence implies basin deepening and infilling with lateritic inputs (Morlock et al., 2019, 2021), limited reductive dissolution of iron oxides in a reduced and oxygenated water column (Sheppard et al., 2020), but substantial diagenetic growth of Fe minerals during burial (Sheppard et al., 2021). On the other hand, continuous crystal growth (Fig. 6B) under saturated pore water conditions may result in strong isotopic zonation in the precipitated phases (Henkel et al., 2016) as the dissolved and residual $\mathrm{Fe}^{2+}$, which is depleted in ${ }^{54} \mathrm{Fe}$, is incorporated from the pore water into the rims of the growing crystals during later diagenesis. In the absence of additional data to constrain such mass balance effect on Fe isotopes, we suggest that these somewhat higher $\delta^{56} \mathrm{Fe}$ values result from the isotopic composition of detrital ferric substrates deposited under oxic bottom water conditions (Henkel et al., 2018), their limited reactivity toward microbial reduction (Friese et al., 2021) and continuous siderite growth under saturated pore water conditions (Vuillemin et al., 2019a) during long-term burial.

As for other $\delta^{56} \mathrm{Fe}$ redox cycling signatures in the water column (Busigny et al., 2014; Camacho et al., 2017) and below the SWI (Liu et al., 2015), the low $\delta^{56}$ Fe values of siderites (-0.2 to $-0.7 \%$ ) and vivianites $\left(-0.4\right.$ to $-0.6 \%$ ) are consistent with kinetic isotope fractionation during microbial $\mathrm{Fe}^{3+}$ reduction under both laboratory (Icopini et al., 2004) and natural settings (Busigny et al., 2014). Assuming constant Fe isotope fractionation factor between siderite and pore water (Henkel et al., 2016), one possibility involves different concentrations of ferric-ferrous precipitates in the sediment whose low $\delta^{56} \mathrm{Fe}$ would be generated prior to deposition during partial redox reactions in bottom waters (Bullen et al., 2001; Anbar, 2004). In this case, lowest $\delta^{56} \mathrm{Fe}$ values associated with green-red clay transitions would inform on the sporadic oxygenation of anoxic bottom waters, during which a higher flux of isotopically light ferrihydrite-like phases could reach the sediment (Scholz et al., 2011). As the main diagenetic end-members, siderites and vivianites could partly reflect $\delta^{56} \mathrm{Fe}$ signatures inherited from the reductive dissolution of these ferric precipitates (Sheppard et al., 2019; Bauer et al., 2020), but also result from Fe isotope fractionation and partitioning due to microbial reduction in Towuti's sediment during early diagenesis (Severmann et al., 2006; Scholz et al., 2014).

\section{Carbon isotopes: OM mineralization, biogenic DIC and methane escape}

In modern Lake Towuti and Matano, stratification of the water body with OM remineralization in the water column results in an overall decrease in $\mathrm{pH}$ (Fig. 5A) and in the associated $\delta^{13} \mathrm{C}$ values of DIC (Fig. 5B), which revolve around $-7.5 \%$ in bottom waters (Kuntz et al., 2015). Nevertheless in both lakes, siderite remains at near-saturation in anoxic bottom waters (Bauer et al., 2020).

In the sediment of Lake Towuti, pore water DIC and methane concentrations (Fig. 3B) continuously increase with depth through the upper 20 mblf. The accumulation of methane implies that methanogenesis 
occurs over $200 \mathrm{ka}$, whereas increasing DIC concentrations indicate that the system is well buffered with respect to $\mathrm{pH}$ (i.e. 6.8 to 7.2 ) and alkalinity (Supplementary Fig. S1) and mainly present in the form of $\mathrm{HCO}_{3}{ }^{-}$. OM remineralization causes rapid saturation in biogenic DIC with respect to siderite (Table 1), thereby initiating its precipitation from pore water at relatively shallow depth in reddish clay (Vuillemin et al., 2019a). VFA concentrations in pore water are further consistent with fermentation processes within the upper 15 mblf (Fig. 3B). VFAs, such as formate and acetate, are central intermediates of anaerobic metabolism and their isotope composition is presumed to cover a large range of $\delta^{13} \mathrm{C}$ values due to microbial processes involved in their production and consumption (Heuer et al., 2006), and their final remineralization to $\mathrm{H}_{2}, \mathrm{CO}_{2}$, and methane (Glombitza et al., 2019; Friese et al., 2021). The rapid turnover of VFAs into $\mathrm{H}_{2}$ and $\mathrm{CO}_{2}$ with concomitant production of methane may in the short term produce very variable $\delta^{13} \mathrm{C}$ values of the DIC incorporated in siderites, and indeed siderite $\delta^{13} \mathrm{C}$ values display large variations in the upper $20 \mathrm{~m}$ of the sediment (Unit 1a). Elsewise according to mass balance during OM remineralization (Boehme et al., 1996), hydrogenotrophic production of biogenic methane from pore water ${ }^{12} \mathrm{CO}_{2}$ enriches the residual DIC in the heavy isotope (Ogrinc et al., 2002; Heuer et al., 2009; Pohlman et al., 2009), resulting in more ${ }^{13} \mathrm{C}$ depleted values for methane (-72.7 to $-63.9 \%$ ) than for $\mathrm{CO}_{2}(-14.5$ to $-11.4 \%$ ) (Figs. 3C and 4A).

Around 10 mblf, the excursion in siderite $\delta^{13} \mathrm{C}$ values (from -0.8 to $-15.1 \%$ ) predates the lake level drop reported for the LGM (Costa et al., 2015; Vogel et al., 2015; Russell et al., 2020), during which siderite $\delta^{13} \mathrm{C}$ values fluctuate between -10.7 and $-4.4 \%$. In the same depth interval, bulk OM (Fig. 3C) recorded inputs mainly derived from the surrounding rainforests $(-32.3$ to $-31.5 \%$ ), whereas the increased presence of $\mathrm{C}_{4}$ grasses in the catchment during the LGM resulted in higher $\delta^{13} \mathrm{C}$ values in bulk OM (-24.5 to $-21.2 \%$ ) between 3 and 8 mblf (Wicaksono et al., 2015). The $\delta^{13} \mathrm{C}$ values of bulk OM and siderites do not covary (Supplementary Fig. S8), which indicates that the $\delta^{13} \mathrm{C}$ signal in siderites does not record the terrestrial and pelagic environmental processes that influence bulk OM. Another possibility is that, during lake-level lowstands and associated fluctuations in bottom waters and sedimentation rates, fermentative gases and dissolved $\mathrm{Fe}^{2+}$ would diffuse out of the sediment and, thereby, affect pore water saturation with respect to siderite in shallow sediment. This would variably deplete the light carbon isotopes from the DIC and result in fluctuating $\delta^{13} \mathrm{C}$ values in siderite, with potential methane oxidation at the SWI (Cadeau et al., 2020).

From 12 to 60 mblf ( $\sim$ Unit $1 \mathrm{~b})$, siderite $\delta^{13} \mathrm{C}$ values are almost identical to those of the dissolved $\mathrm{CO}_{2}$ (-14.5 to -11.4\%o), while VFA concentrations argue for constant decrease in fermentative activity with continuous accumulation of DIC and methane with sediment depth (Figs. 3B-4A). This suggests that siderite $\delta^{13} \mathrm{C}$ compositions in this interval are primarily derived from biogenic $\mathrm{CO}_{2}$ controlled by methylotrophic (72.7 to $-68.8 \%$ ) and hydrogenotrophic (-65.4 to $-67.3 \%$ ) methanogenesis that results in more ${ }^{13} \mathrm{C}$-depleted methane isotope composition than acetoclastic methanogenesis (Penger et al., 2012; Vuillemin et al., 2014a; 
Lecher et al., 2017). Sedimentation rates in this $\sim 600$ ka-long interval are also highly reduced (Fig. 7), which further implies that siderites, although forming in shallow sediments, incorporate DIC over longer time periods. Continuously saturated pore water conditions result in crystal overgrowth on nuclei (Fig. 6B) that partially mutes the pre-depositional signal and mainly records pore water conditions according to a mass balance (Boehme et al., 1996). Highest DIC concentrations are found above a peat layer at $100 \mathrm{mblf}$ that marks the onset of a pelagic lacustrine regime (Fig. 7) transitioning from swamps (Unit 1c) to an early shallow lake system (Russell et al., 2020). Consistent with DIC upward diffusion, the overlying sedimentary red beds contain up to $40 \%$ siderite displaying progressively higher $\delta^{13} \mathrm{C}$ values $(-14.5$ to $3.8 \%$ ) towards the basal peat layer (Figs. 2A and 3A). Under methanogenic conditions and methane degassing toward the surface, anoxic bottom waters and shallow sediment can accumulate isotopically heavy DIC and precipitate siderites with $\delta^{13} \mathrm{C}$ values that are about +5 to $+8 \%$ enriched in ${ }^{13} \mathrm{C}$ compared to those formed in the sediment (Myrbo and Shapley, 2006; Wittkop et al., 2014). Because present-day conditions in Lake Towuti's anoxic bottom waters are under saturation with respect to siderite (Bauer et al., 2020), these heavy ${ }^{13} \mathrm{C}$-enriched values of siderites are the likely result of increased methane production, and potential degassing, from the peaty sediment with incorporation of the residual ${ }^{13} \mathrm{C}$-enriched DIC at an early stage of burial (Cadeau et al., 2020). Similar positive $\delta^{13} \mathrm{C}$ values were reported for siderites in link to biogenic decomposition of wood tar in Baltic Sea sediments (Hałas and Chlebowski, 2004), thereby supporting the present influence of the basal peat layer on Lake Towuti's deepest siderites.

Thus, we interpret the siderite $\delta^{13} \mathrm{C}$ signals as predominantly reflecting post-depositional processes, namely OM mineralization to methane and siderite precipitation with its carbon sourced from biogenic DIC (Fig. 4B) under saturated pore water conditions (Table 1). Because pore waters are saturated with respect to siderite throughout the sediment sequence, crystal growth continues and forms mosaic siderite aggregates on preexisting crystals (Fig. 6B). Linking diagenesis to lithostratigraphy, Unit 1a displays active OM remineralization processes across a sedimentary interval reflecting variable hydrological conditions. Unit $1 \mathrm{~b}$ corresponds with low sedimentation rates and constant precipitation of siderites in chemical equilibrium overprinted by DIC-saturated pore waters, whereas Unit 1c reflects an initial reduced paleolake during which production and diffusion of fermentative gases out of the sediment led to the incorporation of isotopically heavy DIC sources into siderites (Fig. 7).

\section{Combined isotopes: Pre- and post-depositional signatures with extension to the rock record}

Our combined O-Fe-C isotope analyses on siderites (Figs. 4B and $5 \mathrm{C}$ ) demonstrate that the $\delta^{18} \mathrm{O}$ values contain a mixed record of lake water temperatures and isotopic compositions, controlled by lake level fluctuations. Thus, siderites forming at an early stage of burial likely preserve signals from past climatic conditions in their nuclei. However, continuous growth on these pre-existing crystals implies incorporation 
722

723

724

725

726

727

728

729

730

731

732

733

734

735

736

737

738

739

740

741

742

743

744

745

746

747

748

749

750

751

752

753

754

755

of pore water oxygen isotopes, with sector zoning (Dickson, 1991) and variable precipitation rates during sediment OM remineralization (Fronval et al., 1995). Such kinetic effects potentially result in disequilibrium precipitation (Watkins et al., 2013) which lessens applicability of their signatures as paleo-indicators (Johnson et al., 2013; Posth et al., 2014). Although the lowest $\delta^{56} \mathrm{Fe}$ values recorded in siderites may relate to periodic oxygenation of bottom waters and formation of isotopically light ferric precipitates, reductive dissolution of iron phases after deposition implies partition of light $\mathrm{Fe}^{2+}$ isotopes through pore water into variable Fe components in the sediment, with siderites and vivianites as end-members. The degree to which past lacustrine conditions are recorded in siderite Fe isotopic compositions or interwoven with postdepositional processes (Figs. 4B and 7) depends on redox conditions in bottom waters, the isotopic composition of the ferric substrates deposited, whereas subsequent diagenetic overprint relates to diffusion processes across the SWI, reactivity towards microbial Fe reduction and mass balance during overgrowth on nuclei (Supplementary Fig. S9). The $\delta^{13} \mathrm{C}$ values are principally determined by diagenetic pathways of OM degradation reflecting mass balance with incorporation of biogenic $\mathrm{HCO}_{3}{ }^{-}$and associated carbon isotopes in siderite crystals. The heavy $\delta^{13} \mathrm{C}$ values of siderites point to high rates of methanogenesis and consequent ${ }^{13} \mathrm{C}$-enrichment of the residual DIC pool. During low lake levels, sporadic methane degassing from the sediment could result in increased loss of the ${ }^{12} \mathrm{C}$ isotope from the system and possible methane oxidation at the SWI (Supplementary Fig. S9). These processes are active throughout Unit 1a, indicating that OM mineralization continues at least $\sim 200 \mathrm{ka}$ after sediment deposition. In Unit $1 \mathrm{~b}$ which encompasses perhaps $\sim 600 \mathrm{ka}$, isotope signatures are interwoven due to reduced sedimentation rates and diffusion across the SWI. In Unit 1c ( 800 ka - $1 \mathrm{Ma})$, fluvial inflows, lateritic ferric inputs, and methane excess production and diffusion apparently exert the final control on siderite isotope compositions (Fig. 7). As pore water conditions remain saturated with respect to siderite, continuous overgrowth during burial results in crystal coalescence and lithification of sideritic beds over $\sim 1 \mathrm{Ma}$.

The morphologies of siderite crystals in the deep sediment of Lake Towuti (Fig. 6B) display textural similarities to diagenetic siderites and ankerites $\left(\mathrm{CaFe}\left[\mathrm{CO}_{3}\right]_{2}\right)$ described from Precambrian iron formations, as for instance rosettes (Köhler et al., 2013) and cemented spherules (Coleman, 1993). In contrast to primary pelagic precipitates (Konhauser et al., 2005), such spheroidal morphologies have been linked to depositional environments in which increased OM was buried along with iron oxides (Carrigan and Cameron, 1991; Winter and Knauth, 1992; Papineau et al., 2017). Considering ancient ferruginous systems, the relatively short-term environmental variations in Lake Towuti may be compared to shallow environments of the Mesoto Neoproterozoic Era in which siderite strata formed (Tang et al., 2018; Swanner et al., 2020). At the time, redox state in the oceans transitioned between euxinic and ferruginous, with likely short-lived suboxic and oxic conditions (Canfield et al., 2008). During the early Neoproterozoic, the redox chemistry of continental margins further evolved from widespread sulfide-containing conditions to a global ferruginous state 
756 (Guilbaud et al., 2020), with dynamic oxygen levels in the corresponding water column (Planavsky et al.,

757

758

759

760

761

762

763

764

765

766

767

768

769

770

771

772

773

774

775

776

777

778

779

780

781

782

783

784

785

786

787

788

789

2018; Tang et al., 2020). In this context, ancient iron formations such as Banded Iron Formations (Bekker et al., 2014) are considered to derive mostly from hydrothermal fluxes of particulate iron in deep basins (Tosca et al., 2019), whereas terrigenous sources of iron oxides deposited on passive continental margins (Pufahl et al., 2013; Bekker et al., 2014; Tang et al., 2020) are more relevant to Lake Towuti as ferruginous analog (Friese et al., 2021). Factually, Lake Towuti is dominated by external iron inputs weathered from lateritic soils (Morlock et al., 2019). Although particulate iron is partially reduced and dissolved in the water column (Sheppard et al., 2019; Bauer et al., 2020), Lake Towuti displays lesser amount of dissolved iron in its bottom waters (Fig. 1C) relative to past ferruginous margins (Canfield et al., 2018; Tang et al., 2018, 2020), nearby Lake Matano (Bauer et al., 2020) and other meromictic lakes studied as modern ferruginous analogs (Busigny et al., 2016; Camacho et al., 2017; Lambrecht et al., 2018).

The siderite $\delta^{18} \mathrm{O}$ values from modern Lake Towuti were considered to act as a reliable recorder of past hydrological conditions (Ludvigson et al., 2013; van Dijk et al., 2018, 2020) during the LGM and more recent times. Either in marine or freshwater environments (Mozley and Wersin, 1992) and as long as they form close to the SWI (Winter and Knaut, 1992), siderites should inherit their isotope signatures from bottom water temperatures and isotopic compositions (Carrigan and Cameron, 1991). However, diffusion of solutes across the SWI into overlying waters, lasting pore water saturation with respect to siderite (Table 1) during sediment organic carbon remineralization (Hangari et al., 1980; Heimann et al., 2010) and variable precipitation rates with siderite overgrowth on nuclei (Vuillemin et al., 2019a) were considered multiple reasons for potential diagenetic overprint towards lighter $\delta^{18} \mathrm{O}$ values. As such, the $\delta^{18} \mathrm{O}$ signatures of siderite cannot be extrapolated to ancient ferruginous systems in terms of photosynthetic productivity (Crockford et al., 2018) or low-oxygen atmosphere (Planavsky et al., 2020; Reinhard et al., 2020).

In ancient iron formations, the lowest $\delta^{56} \mathrm{Fe}$ values reported for iron carbonates (-2\%) are thought to record a high benthic flux of aqueous $\mathrm{Fe}^{2+}$ produced during microbial reduction under low $\mathrm{O}_{2}$ conditions (Planavsky and Busigny, 2017). In comparison, near-zero and positive $\delta^{56} \mathrm{Fe}$ values of siderites in ancient rocks remain difficult to explain as their formation pathways may involve precipitation from distinct fluids (Wiesli et al., 2004), cation substitutions (Klein, 2005) and post-depositional diagenetic processes (Posth et al., 2014; Tosca et al., 2019) with partial to complete reduction of the reactive iron buried in the sediment (Heimann et al., 2010; Friese et al., 2021). Under limited capture of hydrothermal Fe isotopes as pyritic shales (Planavsky et al., 2012), water-column precipitates and sediment ferrous phases became the main sinks for the isotopically light $\mathrm{Fe}$, which is similar to our present observations in Lake Towuti. We interpreted the mineralogical sequence of Lake Towuti as mostly reflecting variable inputs of detrital iron weathered from the catchment during wet and dry periods, the related lacustrine redox conditions and limited diagenetic overprint during deep burial (Morlock et al., 2021; Sheppard et al., 2021). This shows that 
the host rocks in the catchment exert initial controls on the formation and composition of the lithostratigraphy (Fig. 2). In addition, the sideritic layers above the peat layer and underlying deltaic facies (Figs. 2 and 7) are analogous to certain clay and blackband ironstones (Gibson et al., 1994; Taylor, 2005; Akinlotan, 2017). As such, they may provide clues on depositional conditions and microbial processes (Vuillemin et al., 2016, 2018; Friese et al., 2021) that led to their formation during the Phanerozoic.

Whether siderite layers can be used as a proxy for Proterozoic atmospheric $\mathrm{CO}_{2}(\mathrm{Ohmoto}$ et al., 2014) or not (Gäb et al., 2017) is matter of debate (Heimann et al., 2010). The lack of a secular trend in the Precambrian $\delta^{13} \mathrm{C}$ record is conventionally interpreted in terms of changing proportions of organic to inorganic carbon burial. It has also been proposed that the fairly stable carbon inputs and $\delta^{13} \mathrm{C}$ values result from a high completeness of organic carbon oxidation (Daines et al., 2016; Canfield et al., 2018), with periods of positive carbon isotope excursions reflecting abundant methane degassing to the atmosphere (Cadeau et al., 2020; Sauterey et al., 2020). However, the dynamics of carbon cycling in modern lakes are generally more productive with respect to ancient iron formations (Friese et al., 2021), and most of the recent work on Neoproterozoic and Precambrian environments points to very low productivity (Crockford et al., 2018; Guilbau et al., 2020). Iron formations in particular are known for having anomalously low TOC, which further suggests that DIC sources that resulted in most ${ }^{13} \mathrm{C}$-depleted siderites were either very different (Winter and Knaut, 1992; Ohmoto et al., 2004), or that OM was efficiently oxidized (Carrigan and Cameron, 1991; Canfield et al., 2018).

In Lake Towuti, although siderites preferentially form in OM-poor sediments (Ordoňez et al., 2019), the relatively high TOC content fuels extensive methanogenesis in the sediment. Despite the burial of terrigenous reactive ferric oxides alongside a substantial pool of biogenic methane (Fig. 3), anaerobic oxidation of methane (AOM) was not observed (Vuillemin et al., 2018; Friese et al., 2021). The linear trend of constantly low $\delta^{13} \mathrm{C}$ values (-13\%) reflects incorporation of biogenic DIC from pore water under reduced sedimentation rates that would promote diffusion across the SWI. Positive $\delta^{13} \mathrm{C}$ excursions reflect siderite formation from a residual DIC pool in correlation with ${ }^{12} \mathrm{C}$-enriched biogenic methane, with potential escape from the sediment during periods of low lake level (Figs. 4B and 7). Moreover, the consistent ${ }^{13} \mathrm{C}$ depletion in siderites of Unit $1 \mathrm{~b}$ questions the degree to which methanogenesis is necessary to generate positive $\delta^{13} \mathrm{C}$ excursions in carbonates (Meister and Reyes, 2019). In comparison, the $\delta^{13} \mathrm{C}$ values of siderites above the basal peat layer (i.e. 3.77\%) support extensive methanogenesis, whereas the fluctuating $\delta^{13} \mathrm{C}$ values in relatively shallow sediment of Unit 1a point to a closer coupling between OM remineralization and microbial Fe reduction (Heimann et al., 2010; Friese et al., 2021).

\section{CONCLUSIONS}


822 Our data show that, in ferruginous Lake Towuti, short environmental in-lake variations and early diagenesis

823

824

825

826

827

828

829

830

831

832

833

834

835

836

837

838

839

840

841

842

843

844

845

846

847

848

849

850

851

852

853

854

at shallow depths of burial determine the combined $\mathrm{O}-\mathrm{Fe}-\mathrm{C}$ isotope signatures recorded by siderites, namely lake levels, redox conditions in bottom waters, sedimentation rates, diagenetic evolution of pore water geochemistry, and mass balance during OM remineralization as the main factors. Although the mineralogical features of siderites and their irregular distribution down core result from variability in depositional fluxes of ferric iron and OM to the SWI, the isotopic signatures of these siderites are dominantly influenced by dissimilatory reactions and sediment early diagenesis over water column processing at a relatively early stage of burial. Recording of pre-depositional versus post-depositional processes appears dependent on sedimentation rates as diffusion across the SWI tends to align the signatures of siderites either on those of the lake bottom or sediment pore waters. Strongly negative $\delta^{13} \mathrm{C}$ values of siderite clearly reflect a carbon source provided by sustained OM remineralization in the sediment in the absence of AOM, whereas more positive $\delta^{13} \mathrm{C}$ values indicate increased production of biogenic methane and its potential escape from the sediment during early burial. Finally, the influence of crystal overgrowth on nuclei over the $\sim 1$ Ma studied here requires further investigations in terms of oxygen and iron isotopes incorporation from pore water. The combined isotopic trends measured on siderites and the geochemical evolution of pore waters during burial allow placing constraints on the timescale of active diagenetic mineral growth, which is presently assessed to $200 \mathrm{ka}$ and $\sim 1 \mathrm{Ma}$ for biotic and abiotic processes, respectively.

Because high depositional fluxes of ferric iron and OM in early oceans would have promoted microbial processes in ferruginous deposits prior to their lithification, microbial imprint of isotope signatures with overgrowth of siderite nuclei during shallow burial has to be taken into account in interpreting carbonate concretions and siderite strata from the ancient rock record.

\section{ACKNOWLEDGEMENTS}

This research was carried out with support from the International Continental Scientific Drilling Program (ICDP), the U.S. National Science Foundation (NSF), the German Research Foundation (DFG), the Swiss National Science Foundation (SNSF), PT Vale Indonesia, the Ministry of Research, Education, and Higher Technology of Indonesia (RISTEK), Brown University, University of Minnesota, University of Geneva, GFZ German Research Centre for Geosciences, the Natural Sciences and Engineering Research Council of Canada (NSERC), and Genome British Columbia. This study was financially and logistically supported by the ICDP priority program of the DFG through grants to JK (KA 2293/8-1) and AV (VU 94/1-1), an SNSF grant to AV (P2GEP2_148621) and an NSERC Discovery grant (0487) to SAC.

We thank PT Vale Indonesia, the U.S. Continental Scientific Drilling and Coordination Office, the U.S. National Lacustrine Core Repository, and DOSECC Exploration Services for logistical support. Research permits were obtained from RISTEK, the Ministry of Trade of the Republic of Indonesia, the 
855

856

857

858

859

860

861

862

863

864

865

866

867

868

869

870

871

872

873

874

875

876

877

878

879

880

881

882

883

884

885

886

887

Natural Resources Conservation Center (BKSDA), and the Government of Luwu Timur of Sulawesi. We thank Tri Widiyanto, the director of the Indonesia Research Center for Limnology, and his staff for their administrative support in obtaining the Scientific Research Permit. Supervision by the scientific crew of LacCore during core processing is kindly acknowledged. J. Schlegel and J. Buhk are acknowledged for laboratory support at GFZ (HELGES) and the Helmholtz Association for infrastructure support at GFZ. We also thank A. Schreiber, H. Kemnitz, I. Schäpan and J. Glodny at the GFZ for assistance during XRD and SEM analyses and mineral extractions, R. Höfner-Stich and A. Beyer for assistance with oxygen and carbon isotopes analyses, and A. Dianto for his participation in field sampling. The Towuti Drilling Project Science Team actively participated in drilling operations and processing of the cores at LacCore.

The present scientific data are archived and publicly available from the PANGAEA ${ }^{\circledR}$ Data Publisher for Earth and Environmental Science (datasets \#908080 and \#934401) (Vuillemin et al., 2019b, 2021).

\section{REFERENCES CITED}

Akinlotan, O., 2017, Sideritic ironstones as indicators of depositional environments in the Weald Basin (Early Cretaceous) SE England: Geological Magazine, v. 156, p. 533-546, https://doi.org/10.1017/S0016756817001017.

Anbar, A.D., 2004, Iron stable isotopes: beyond biosignatures: Earth and Planetary Science Letters, v. 217, p. 223-236, https://doi.org/10.1016/s0012-821x(03)00572-7.

Bachan, A., and Kump, L.R., 2015, The rise of oxygen and siderite oxidation during the Lomagundi Event: Proceedings of the National Academy of Sciences of the United States of America, v. 112, p. 65626567, https://doi.org/10.1073/pnas.1422319112.

Bauer, K.W., Gueguen, B., Cole, D.B., Francois, R., Kallmeyer, J., Planavsky, N., Crowe, S.A., 2018, Chromium isotope fractionation in ferruginous sediments: Geochimica and Cosmochimica Acta, v. 223, p. 198-215, https://doi.org/10.1016/j.gca.2017.10.034.

Bauer, K.W. et al., 2020, Magnetite biomineralization in ferruginous waters and early Earth evolution: Earth and Planetary Science Letters, v. 549, p. 116495, https://doi.org/10.1016/j.eps1.2020.116495.

Bekker, A., Planavsky, N., Rasmussen, B., Krapez, B., Hofmann, A., Slack, J., Rouxel, O., and Konhauser, K., 2014, Iron formations: Their origins and implications for ancient seawater chemistry, in Holland, H.D., and Turekian, K.K., eds., Treatise on Geochemistry, Elsevier, v. 9, p. 561-628, https://doi.org/10.1016/B978-0-08-095975-7.00719-1.

Bjørlykke, K., 2015, Compaction of Sedimentary Rocks: Shales, Sandstones, and Carbonates, in Bjørlykke, K., ed., Petroleum Geoscience: From Sedimentary Environments to Rock Physics, Springer, ch. 13, p. 351-360, https://doi.org/10.1007/978-3-642-34132-8_13.

Boehme, S.E., Blair, N.E., Chanton, J.P., and Martens, C.S., 1996, A mass balance of ${ }^{13} \mathrm{C}$ and ${ }^{12} \mathrm{C}$ in an 
organic-rich methane-producing marine sediment: Geochimica et Cosmochimica Acta, v. 60, p. 3835-3848, https://doi.org/10.1016/0016-7037(96)00204-9.

Bray, M.S. Wu, J., Reed, B.C., Kretz, C.B., Belli, K.M., Simister, R.L. Henny, C., Stewart, F.J., Di Christina, T.J., Brandes, J.A., Fowle, D.A. Crowe, S.A., and Glass, J.B., 2017, Shifting microbial communities sustain multiyear iron reduction and methanogenesis in ferruginous sediment incubations: Geobiology, v. 15, p. 678-689, https://doi.org/10.1111/gbi.12239.

Brewer, P.G., and Spencer, D.W., 1971, Colorimetric determination of manganese in anoxic waters 1: Limnology and Oceanography, v. 16, p. 107-110, https://doi.org/10.4319/lo.1971.16.1.0107.

Bullen, T.D., White, A.F., Childs, C.W., Vivit, D.V., and Schulz, M.S., 2001, Demonstration of significant abiotic iron isotope fractionation in nature: Geology, v. 29, p. 699-702, https://doi.org/10.1130/00917613(2001)029<0699:DOSAII>2.0.CO;2.

Busigny, V., Jézéquel, D., Cosmidis, J., Viollier, E., Benzerara, K., Planavsky, N.J., Albéric, P., Lebeau, O., Sarazin, G., and Michard, G., 2016, The Iron Wheel in Lac Pavin: Interaction with Phosphorus Cycle in Sime-Ngando, T., Boivin, P., Chapron, E., Jezequel, D., Meybeck, M., eds., Lake Pavin: History, geology, biogeochemistry, and sedimentology of a deep meromictic maar lake, Springer, ch. 12, p. 205-220, https://doi.org/10.1007/978-3-319-39961-4_12.

Busigny, V., Planavsky, N.J., Jézéquel, D., Crowe, S., Louvat, P., Moureau, J., Viollier, E., and Lyons, T.W., 2014, Iron isotopes in an Archean ocean analogue: Geochimica et Cosmochimica Acta, v. 133, p. 443-462, https://doi.org/10.1016/j.gca.2014.03.004.

Cadeau, P. et al., 2020, Carbon isotope evidence for large methane emissions to the Proterozoic atmosphere: Scientific Reports, v.10, e18186, https://doi.org/10.1038/s41598-020-75100-X.

Camacho, A., Walter, X.A., Picazo, A., and Zopfi, J., 2017, Photoferrotrophy: Remains of an ancient photosynthesis in modern environments: Frontiers in Microbiology, v. 8, e323, https://doi.org/10.3389/fmicb.2017.00323.

Canfield, D.E., Poulton, S.W., Knoll, A.H., Narbonne, G.M., Ross, G., Goldberg, T., and Strauss, H., 2008, Ferruginous conditions dominated later Neoproterozoic deep-water chemistry: Science, v. 321, p. 949-952, https://doi.org/doi: 10.1126/science.1154499.

Canfield, D.E., Zhang, S., Wang, H., Wang, X., Zhao, W., Su, J., Bjerrum, C.J., Haxen, E.R., and Hammarlund, E.U., 2018, A Mesoproterozoic iron formation: Proceedings of the National Academy of Sciences of the United States of America, v. 115, p. E3895-E3904, https://doi.org/10.1073/pnas.1720529115.

Carrigan, W.J., and Cameron, E.M., 1991, Petrological and stable isotope studies of carbonate and sulfide minerals from the Gunflint Formation, Ontario: evidence for the origin of early Proterozoic ironformation: Precambrian Research, v. 52, p.347-380, https://doi.org/10.1016/0301-9268(91)90088-R. 
922

923

924

925

926

927

928

929

930

931

932

933

934

935

936

937

938

939

940

941

942

943

944

945

946

947

948

949

950

951

952

953

954

955

Carothers, W.W., Adami, L.H., and Rosenbauer, R.J., 1988, Experimental oxygen isotope fractionation between siderite-water and phosphoric acid liberated $\mathrm{CO}_{2}$-siderite: Geochimica et Cosmochimica Acta, v. 52, p. 2445-2450, https://doi.org/10.1016/0016-7037(88)90302-X.

Coleman, M.L., 1993, Microbial processes: Controls on the shape and composition of carbonate concretions: Marine Geology, v. 113, p. 127-140, https://doi.org /10.1016/0025-3227(93)90154 -N.

Coplen, T.B., Kendall, C., and Hopple, J., 1983, Comparison of stable isotope reference samples: Nature, v. 302, p. 236-238, https://doi.org/10.1038/302236a0.

Costa, K.M., Russell, J.M., Vogel, H., and Bijaksana, S., 2015, Hydrological connectivity and mixing of Lake Towuti, Indonesia in response to paleoclimatic changes over the last 60,000 years:

Palaeogeography, Palaeoclimatology, Palaeoecology, v. 417, p. 467-475, https://doi.org/10.1016/j.palaeo.2014.10.009.

Coward, E.K., Thompson, A.T., and Plante, A.F., 2017, Iron-mediated mineralogical control of organic matter accumulation in tropical soils: Geoderma, v. 306, p. 206-216, https://doi.org/10.1016/j.geoderma.2017.07.026.

Craddock, P.R., and Dauphas, N., 2011, Iron and carbon isotope evidence for microbial iron respiration throughout the Archean: Earth and Planetary Science Letters, v. 303, p. 121-132, https://doi.org/10.1016/j.epsl.2010.12.045.

Crockford, P.W., Hayles, J.A., Bao, H., Planavsky, N.J., Bekker, A., Fralick, P.W., Halverson, G.P., Bui, T.H., Peng, Y., and Wing, B.A., 2018, Triple oxygen isotope evidence for limited mid-Proterozoic primary productivity: Nature, v. 559, p. 613-616, https://doi.org/10.1038/s41586-018-0349-y.

Crowe, S.A., Roberts. J.A., Weisener, C.G., and Fowle, D.A., 2007: Alteration of iron-rich lacustrine sediments by dissimilatory iron-reducing bacteria: Geobiology, v. 5, p. 63-73, https://doi.org/10.1111/j.1472-4669.2006.00086.x.

Crowe, S.A., O’Neill, A.H., Katsev, S., Hehanussa, P., Haffner, G.D., Sundby, B., Mucci, A., and Fowle, D.A., 2008a, The biogeochemistry of tropical lakes: A case study from Lake Matano, Indonesia: Limnology and Oceanography, v. 53, p. 319-331, https://doi.org/10.4319/1o.2008.53.1.0319.

Curtis, C.D., 1985, Clay mineral precipitation and transformation during burial diagenesis: Philosophical Transactions of the Royal Society of London A, v. 315, p. 91-105, https://doi.org/10.1098/rsta.1985.0031.

Dam, R.A.C., Fluin, J., Suparan, P., and van der Kaars, S., 2001, Palaeoenvironmental developments in the Lake Tondano area (N. Sulawesi, Indonesia) since 33,000 yr B.P.: Palaeogeography Palaeoclimatology Palaeoecology, v. 171, p. 147-183, https://doi.org/10.106/S0031-0182(01)002449.

Daines, S.J., Mills, B.J.W., and Lenton T.M., 2016, Atmospheric oxygen regulation at low Proterozoic levels 
by incomplete oxidative weathering of sedimentary organic carbon: Nature Communications, v. 8 , e14379, https://doi.org/10.1038/ncomms14379.

Dickson, J.A.D., 1991, Disequilibrium carbon and oxygen isotope variations in natural calcite: Nature, v. 353, p. 842-844, https://doi.org/10,1038/353842a0.

Dideriksen, K., Baker, J.A., and Stipp, S.L.S., 2006, Iron isotopes in natural carbonate minerals determined by MC-ICP-MS with a ${ }^{58} \mathrm{Fe}-{ }^{54} \mathrm{Fe}$ double spike: Geochimica et Cosmochimica Acta, v. 70, p. 118 132, https://doi.org/10.1016/j.gca.2005.08.019.

Driese, S.G., Ludvigson, G.A., Roberts, G.A., Roberts, J.A., Fowle, D.A., González L.A., Smith, J.J., Vulava, V.M., and McKay, L.D., 2010, Micromorphology and stable-isotope geochemistry of historical pedogenic siderite formed in PAH-contaminated alluvial clay soils, Tennessee, U.S.A.: Journal of Sedimentary Research, v. 80, p. 943-954, https://doi.org/10.2110/jsr.2010.087.

Fernandez, A., van Dijk, J., Müller, I.A., and Bernasconi, S.M., 2016, Siderite acid fractionation factors for sealed and open vessel digestions at $70^{\circ} \mathrm{C}$ and $100^{\circ} \mathrm{C}$ : Chemical Geology, v. 444, p. 180-186, https://doi.org/10.1016/j.chemgeo.2016.10.015.

Friese, A. et al., 2021, Organic matter mineralization in modern and ancient ferruginous sediments: Nature Communications v. 6, e2216, https://doi.org/10.1038/s41467-021-22453-0.

Friese, A., Kallmeyer, J., Axel Kitte, J., Montaño Martínez, I., Bijaksana, S., Wagner, D., and the ICDP Lake Chalco Drilling Science Team and the ICDP Towuti Drilling Science Team, 2017, A simple and inexpensive technique for assessing contamination during drilling operations: Limnology and Oceanography Methods, v. 15, p. 200-211, https://doi.org/10.1002/lom3.10159.

Fronval, T., Jensen, N.B., and Buchardt, B., 1995, Oxygen isotope disequilibrium precipitation of calcite on Lake Arresø, Denmark: Geology, v. 23, p. 463-466, https://doi.org/10,1130/00917613(1995)023<0463:OIDPOC $>2.3 . C O ; 2$.

Furrer, G., and Wehrli, B., 1996, Microbial reactions, chemical speciation, and multicomponent diffusion in pore waters of a eutrophic lake: Geochimica et Cosmochimica Acta, v.60, p. 2333-2346, https://doi.org/10.1016/0016-7037(96)00086-5.

Gäb, F., Ballhaus, C., Siemens, J., Heuser, A., Lissner, M., Geisler, T., and Garbe-Schönberg, D., 2017, Siderite cannot be used as CO2 sensor for Archaean atmospheres: Geochimica et Cosmochimica Acta, v. 2014, p. 209-225, https://doi.org/10.1016/j.gca.2017.07.027.

Gibson, P.J., Shaw, H.E., and Spiro, B., 1994, The nature and origin of sideritic ironstone bands in the tertiary Lowmead and Duaringa Basins, Queensland: Australian Journal of Earth Sciences, v. 41, p. 255-263, https://doi.org/10.1080/08120099408728134.

Guilbaud, R., Poulton, S.W., Thompson, J., Husband, K.F., Zhu, M., Zhou, Y., Shields, G.A., and Lenton, T.M., 2020, Phosphorus-limited conditions in the early Neoproterozoic ocean maintained low levels 
of atmospheric oxygen: Nature Geoscience, v. 13, p. 296-301, https://doi.org/10.1038/s41561-0200548-7.

Glombitza, C., Egger, M., Røy, H., and Jørgensen, B.B., 2019, Controls on volatile fatty acid concentrations in marine sediments (Baltic Sea): Geochimica et Cosmochimica Acta, v. 258, p. 226-241, https://doi.org/10.1016/j.gca.2019.05.038.

Glombitza, C., Pedersen, J., Røy, H., and Jørgensen, B.B., 2014, Direct analysis of volatile fatty acids in marine sediment porewater by two-dimensional ion chromatography-mass spectrometry: Limnology and Oceanography Methods, v. 12, p. 455-468, https://doi.org/10.4319/lom.2014.12.455.

Golightly, J.P., 2010, Progress in understanding the evolution of nickel laterites: The Challenge of Finding New Mineral Resources: Global Metallogeny, Innovative Exploration, and New Discoveries, v. 2, p. 451-475, https://doi.org/10.5382/SP.15.2.07.

Hałas, S., and Chlebowski, R., 2004, Unique siderite occurrence in Baltic Sea: a clue to siderite-water oxygen isotope fractionation at low temperatures: Geological Quarterly, v. 48, p. 317-322, https://gq.pgi.gov.pl/article/view/7355.

Halevy, I., Alesker, M., Schuster, E.M., Popovitz-Biro, R., and Feldman, Y., 2017, A key role for green rust in the Precambrian oceans and the genesis of iron formations: Nature geoscience, v. 10, p. 135-139, https://doi.org/10.1038/ngeo2878.

Hangari, K.M., Ahmad, S.N., and Perry, E.C.Jr., 1980, Carbon and oxygen isotope ratios in diagenetic siderite and magnetite from Upper Devonian ironstone, Wadi Shatti District, Libya: Economic Geology, v. 75, p. 538-545, http://dx.doi.org/10.2113/gsecongeo.75.4.538.

Hasberg, A.K.M., Bijaksana, S., Held, P., Just, J., Melles, M., Morlock, M.A., Opitz, S., Russell, J.M., Vogel, H., and Wennrich, V., 2019, Modern sedimentation processes in Lake Towuti, Indonesia, revealed by the composition of surface sediments: Sedimentology, v. 66, p. 675-698, https://doi.org/10.1111/sed.12503.

He, Y., Ke, S., Teng, F.-Z., Wang, T., Wu, H., Lu, Y., and Li, S., 2015, High-precision iron isotope analysis of geological reference materials by high-resolution mc-icp-ms: Geostandards and Geoanalytical Research, v. 39, p. 341-356, https://doi.org/10.1111/j.1751-908X.2014.00304.x.

Heimann, A., Johnson, C.M., Beard, B.L., Valley, J.W., Roden, E.E., Spicuzza, M.J., and Beukers, N.J., 2010, Fe, C, and O isotope compositions of banded iron formation carbonates demonstrate a major role for dissimilatory iron reduction in $\sim 2.5$ Ga marine environments: Earth and Planetary Science Letters, v. 294, p. 8-18, https://doi.org/10.1016/j.eps1.2010.02.015.

Heinrich, L., Rothe, M., Braun, B., and Hupfer, M., 2020, Transformation of redox-sensitive to redox-stable iron-bound phosphorus in anoxic lake sediments under laboratory conditions: Water Research, v. 189, e116609, https://doi.org/10.1016/j.watres.2020.116609. 
1024

1025

1026

1027

1028

1029

1030

1031

1032

1033

1034

1035

1036

1037

1038

1039

1040

1041

1042

1043

1044

1045

1046

1047

1048

1049

1050

1051

1052

1053

1054

1055

1056

1057

Henkel, S., Kasten, S., Poulton, S.W., and Staubwasser, M., 2016, Determination of the stable iron isotopic composition of sequentially leached iron phases in marine sediments: Chemical geology, v. 421, p. 93-102, https://doi.org/10.1016/j.watres.2020.116609.

Henkel, S., Kasten, S., Hartmann, J.F., Silva-Busso, A., and Staubwasser, M., 2018, Iron cycling and stable Fe isotope fractionation in Antarctic shelf sediments, King George Island: Geochimica et Cosmochimica Acta, v. 237, p. 320-338, https://doi.org/10.1016/j.gca.2018.06.042.

Hesslein, R.H., 1980, In situ measurements of pore water diffusion coefficients using tritiated water: Canadian Journal of Fisheries and Aquatic Sciences, v. 37, p. 545-551, https://doi.org/10.1139/f80069.

Heuer, V.B., Elvert, M., Tille, S., Krummen, M., Mollar, X.P., Hmelo, L.R., and Hinrichs, K.-U., 2006, Online $\delta^{13} \mathrm{C}$ analysis of volatile fatty acids in sediment/porewater systems by liquid chromatographyisotope ratio mass spectrometry: Limnology and Oceanography Methods, v. 4, p.346-357, https://doi.org/10.4319/lom.2006.4.346.

Heuer, V.B., Pohlman, J.W., Torres, M.E., Elvert, M., and Hinrichs, K.-U., 2009, The stable carbon isotope biogeochemistry of acetate and other dissolved carbon species in deep subseafloor sediments at the northern Cascadia Margin: Geochimica et Cosmochimica Acta, v. 73, p. 3323-3336, https://doi.org/10.1016/j.gca.2009.03.001.

Holland, H.D., 2006, The oxygenation of the atmosphere and oceans: Philosophical Transactions of the Royal Society B: Biological Sciences, v. 361, p. 903-915, https://doi.org/10.1098/rstb.2006.1838. Hope, G., 2001, Environmental change in the late Pleistocene and later Holocene at Wanda site, Soroako, South Sulawesi, Indonesia: Palaeogeography Palaeoclimatology Palaeoecology, v.191, p. 129-145, https://doi.org/10.1016/S0031-0182(01)00243-7.

Icopini, G.A., Anbar, A.D., Ruebush, S.S., Tien, M., and Brantley, S.L., 2004, Iron isotope fractionation during microbial reduction of iron: The importance of adsorption: Geology, v. 32, p. 205, https://doi.org/10.1130/g20184.1.

Islam, M.A., 2004, Einstein-Smoluchowski diffusion equation: A discussion: Physica Scripta, v. 70, p. 120125, https://doi.org/10.1088/0031-8949/70/2-3/008.

Jiang, C., Chen, Z., Lavoie, D., Percival, J.B., and Kabanov, P., 2017, Mineral carbon MinC(\%) from RockEval analysis as a reliable and cost-effective measurement of carbonate contents in shale source and reservoir rocks: Marine and Petroleum Geology, v. 83, p. 184-194, https://doi.org/10.1016/j.marpetgeo.2017.03.017.

Jiang, C.Z., and Tosca, N.J., 2019: Fe(II)-carbonate precipitation kinetics and the chemistry of anoxic ferruginous seawater: Earth and Planetary Science Letters, v. 506, p. 231-242, https://doi.org/10.1016/j.epsl.2018.11.010. 
Johnson, C.M., and Beard, B.L., 2008, The iron isotope fingerprints of redox and biogeochemical cycling in modern and ancient Earth: Annual Reviews of Earth and Planetary Sciences, https://doi.org/10.1146/annurev.earth.36.031207.124139.

Johnson, C.M., Ludois, J.M., Beard, B.L., Beukes, N.J., and Heimann, A., 2013, Iron formation carbonates: Paleoceanographic proxy or recorder of microbial diagenesis? Geology, v. 41, p. 1147-1150, https://doi.org/10.1130/G34698.1.

Jones, C., Crowe, S.A., Sturm, A., Leslie, K.L., MacLean, L.C.W., Katsev, S., Henny, C., Fowle, D.A., and Canfield, D.E., 2011, Biogeochemistry of manganese in Lake Matano, Indonesia: Biogeosciences, v. 8, p. 4063-4106, https://doi.org/10.5194/bgd-8-4063-2011.

Kallmeyer, J., 2017: Contamination control for scientific drilling operations: Advances in Applied Microbiology, v. 98, p. 61-91, https://doi.org/10.1016/bs.aambs.2016.09.003.

Katsev, S., Crowe, S.A., Mucci, A., Sundby, B., Nomosatryo, S., Haffner, D.G., and Fowle, D.A., 2010, Mixing and its effects on biogeochemistry in the persistently stratified, deep, tropical Lake Matano, Indonesia: Limnology and Oceanography, v. 55, p. 763-776, https://doi.org/10.4319/1o.2010.55.2.0763.

Klein, C., 2005, Some Precambrian banded iron-formations (BIFs) from around the world: Their age, geologic setting, mineralogy, metamorphism, geochemistry, and origins: The American Mineralogist, v. 90, p. 1473-1499, https://doi.org/10.2138/am.2005.1871.

Köhler, I., Konhauser, K.O., Papineau, D., Bekker, A., and Kappler, A., 2013, Biological carbon precursor to diagenetic siderite with spherical structures in iron formations: Nature Communications, v. 4, e1741, https:doi.org/10.1038/ncomms2770.

Konecky, B., Russell, J., and Bijaksana, S., 2016, Glacial aridity in central Indonesia coeval with intensified monsoon circulation: Earth and Planetary Science Letters, v. 437, p. 15-24, https://doi.org/10.1016/j.eps1.2015.12.037.

Konhauser, K., Newman, D.K., and Kappler, A., 2005, The potential significance of microbial Fe(III) reduction during deposition of Precambrian banded iron formations: Geobiology, v. 3, p. 167-177, https://doi.org /10.1111/j.1472-4669.2005.00055.x.

Kump, L.R., Junium, C., Arthur, M.A., Brasier, A., Fallick, A., Melezhik, V., Lepland, A., Crne, A.E., and Luo, G., 2011, Isotopic evidence for massive oxidation of organic matter following the great oxidation event: Science, v. 334, p. 1694-1696, https://doi.org/10.1126/science.1213999.

Kuntz, L.B., Laakso, T.A., Schrag, D.P., and Crowe S.A., 2015, Modeling the carbon cycle in Lake Matano: Geobiology, v. 5, p. 454-461, https://doi.org/10.1111/gbi.12141.

Lamb, H.F., Leng, M.J., Telford, R.J., Ayenew, T., and Umer, M., 2006, Oxygen and carbon isotope composition of authigenic carbonate from an Ethiopian lake: a climate record of the last 2000 years: 
The Holocene, v. 17, p. 517-526, https://doi.org/10.1177/0959683607076452.

Lambrecht, N., Wittkop, C., Katsev, S., Fakhraee, M., and Swanner, E.D., 2018, Geochemical characterization of two ferruginous meromictic lakes in the Upper Midwest, USA: JGR Biogeosciences, v. 123, p. 3403-3422, https:/doi.org/10.1029/2018JG004587.

Lebeau, O., Busigny, V., Chaduteau, C., and Ader, M., 2014, Organic matter removal for the analysis of carbon and oxygen isotope compositions of siderite: Chemical Geology, v. 372, p. 54-61, https://doi.org/10.1016/j.chemgeo.2014.02.020.

Lecher, A.L., Chuang, P.-C., Singleton, M., and Paytan, A., 2017, Sources of methane to an Arctic lake in Alaska: An isotopic investigation: JGR Biogeosciences, v. 122, p. 753-766, https://doi.org/10.1002/2016JG003491.

Leemakers, M., Mbachou, B.E., Husson, A., Lagneau, V., and Descostes, M., 2019, An alternative sequential extraction scheme for the determination of trace elements in ferrihydrite rich sediments: Talanta, v. 199, p. 80-88, https://doi.org/10.1016/j.talanta.2019.02.053.

Leng, M.J., and Marshall, J.D., 2004, Palaeoclimate interpretation of stable isotope data from lake sediment archives: Quaternary Science Reviews, v. 23, p. 811-831, https://doi.org/10.1016/j.quascirev.2003.06.012.

Leng, M.J., Lamb, A.L., Heaton, T.H.E., Marshall, J.D., Wolfe, B.B., Jones, M.D., Holmes, J.A., and Arrowsmith, C., 2006: Isotopes in lake sediments, in: Leng, M.J., ed., Isotopes in Palaeoenvironmental Research.: Springer, Dordrecht, Developments in Paleoenvironmental Research 10, p. 147-184, https://doi.org/10.1007/1-4020-2504-1_04.

Li, H., Liu, X., Tripati, A., Feng, S., Elliott, B., Whicker, C., Arnold, A., and Kelley, A.M., 2020, Factors controlling the oxygen isotopic composition of lacustrine authigenic carbonates in Western China: Implications for paleoclimate reconstructions: Scientific Reports, v. 10, e16370, https://doi.org/10.1038/s41598-020-73422-4.

Liu, W., Li,X., Zhang, L., An, Z., and Xu, L., 2014, Evaluation of oxygen isotopes in carbonate as an indicator of lake evolution in arid areas: The modern Qinghai Lake, Qinghai-Tibet Plateau: Chemical Geology, v. 268, p.126-136, https://doi.org/10.1016/j.chemgeo.2009.08.004.

Liu, K., Wu, L., Couture, R.-M., Li, W., and Van Cappellen, P., 2015, Iron isotope fractionation in sediments of an oligotrophic freshwater lake: Earth and Planetary Science Letters, v. 423, p. 164172, https://doi.org/10.1016/j.eps1.2015.05.010.

Ludvigson, G.A., González, L.A., Fowle, D.A., Roberts, J.A., Driese, S.G., Villarreal, M.A., Smith J.J., and Suarez, M.B., 2013, Paleoclimatic applications and modern process of pedogenic siderite, in Driese, S.G., and Nordt L.C., eds., New Frontiers in Paleopedology and Terrestrial Paleoclimatology: Paleosols and Soil Surface Analog Systems, SEPM Society of Sedimentary Geology, v. 104, p. 79- 
88, https://doi.org/10.2110/sepmsp.104.

1127

1128

1129

1130

1131

1132

1133

1134

1135

1136

1137

1138

1139

1140

1141

1142

1143

1144

1145

1146

1147

1148

1149

1150

1151

1152

1153

1154

1155

1156

1157

1158

1159

Lyons, T.W., Reinhard, C.T., and Planavsky, N.J., 2014, The rise of oxygen in Earth's early ocean and atmosphere: Nature, v. 506, p. 307-315, https://doi.org/10.1038/nature13068.

Maier, D.B., Rydberg, J., Bigler, C., and Renberg, I., Compaction of recent varved lake sediments: GFF, v. 135, p. 231-236, https://doi.org/10.1080/11035897.2013.788551.

Majestic, B.J., Schauer, J.J., and Shafer, M.M., 2007, Development of a manganese speciation method for atmospheric aerosols in biologically and environmentally relevant fluids: Aerosol Science and Technology, v. 41, p. 925-933, https://doi.org/10.1080/02786820701564657.

Mayr, C. et al., 2007, Precipitation origin and evaporation of lakes in semi-arid Patagonia (Argentina) inferred from stable isotopes $\left(\delta^{18} \mathrm{O}, \delta^{2} \mathrm{H}\right)$ : Journal of Hydrology, v. 334, p. 53-63, https://doi.org/10.1016/j.jhydrol.2006.09.025.

McCoy, V.E., Asael, D., and Planavsky, N., 2016, Benthic iron cycling in a high-oxygen environment: Implications for interpreting the Archean sedimentary iron isotope record: Geobiology, v. 15, p. 619627, https://doi.org/10.1111/gbi.12247.

Meister, P., and Reyes, C., 2019, The carbon-isotope record of the sub-seafloor biosphere: Geosciences, v. 9 , p. 1-25, https://doi.org/10.3390/geosciences9120507.

Moeller, K., Schoenberg, R., Grenne, T., Thorseth, I.H., Drost, K., and Pedersen, R.B., 2014, Comparison of iron isotope variations in modern and Ordovician siliceous Fe oxyhydroxide deposits: Geochimica et Cosmochimica Acta, v. 126, p. 422-440, https://doi.org/10.1016/j.gca.2013.11.018.

Morlock, M.A., Vogel, H., Russell, J.M., Anselmetti F.S., and Bijaksana S., 2021, Quaternary environmental changes in tropical Lake Towuti, Indonesia, inferred from end-member modeling of X-ray fluorescence core-scanning data: Journal of Quaternary Science, v. 36, p. 1040-1051, https://doi.org/10.1002/jqs.3338.

Morlock, M.A., Vogel, H., Nigg, V., Ordoñez, L., Hasberg, A.K.M., Melles, M., Russell, J.M., Bijaksana, S., and the TDP Science Team, 2019, Climatic and tectonic controls on source-to-sink processes in the tropical, ultramafic catchment of Lake Towuti, Indonesia: Journal of Paleolimnology, v. 61, p. 279-295, https://doi.org/10.1007/s10933-018-0059-3.

Mortimer, R.J.G., and Coleman, M.L., 1997, Microbial influence on the oxygen isotopic composition of diagenetic siderite: Geochimica et Cosmochimica Acta, v. 61, p. 1705-1711, https://doi.org/10.1016/s0016-7037(97)00027-6.

Mortimer, R.J.G., Coleman, M.L., and Rae, J.E., 1997, Effect of bacteria on the elemental composition of early diagenetic siderite: implications for palaeoenvironmental interpretations: Sedimentology, v. 44, p. 759-765, https://doi.org/10.1046/j.1365-3091.1997.d01-45.x.

Mozley, P.S., and Wersin, P., 1992, Isotopic composition of siderite as an indicator of depositional 
environment: Geology, v. 20, p. 817-820, https://doi.org/10.1130/00917613(1992)020<0817:ICOSAA>2.3.CO;2.

Murphy, J., and Riley, J.P., 1962, A modified single solution method for the determination of phosphate in natural waters: Analytica Chimica Acta, v. 27, p. 31-36, https://doi.org/10.1016/S00032670(00)88444-5.

Myrbo, A., and Shapley, M.D., 2006, Seasonal water-column dynamics of dissolved inorganic carbon stable isotopic compositions ( $\delta 13 \mathrm{CDIC}$ ) in small hardwater lakes in Minnesota and Montana: Geochimica et Cosmochimica Acta, v. 70, p. 2699-2714, https://doi.org/10.1016/j.gca.2006.02.010.

Oehlerich, M., Baumer, M., Lücke, A., and Mayr, C., 2013, Effects of organic matter on carbonate stable isotope ratios $\left(\delta^{13} \mathrm{C}, \delta^{18} \mathrm{O}\right.$ values $)$ - implications for analyses of bulk sediments: Rapid Communications in Mass Spectrometry, v. 27, p. 707-712, https://doi.org/10.1002/rcm.6492.

Oehlerich, M., Mayr, C., Hölzl, S., Rummel, S., Teichert, B.M.A., Gussone, N., Hahn, A., Lücke, A., Ohlendorf, C., Zolitschka, B., 2015, Lateglacial and Holocene climatic changes in south-eastern Patagonia inferred from carbonate isotope records of Laguna Potrok Aike (Argentina): Quaternary Science Reviews, v. 114, p. 189-202, https://doi.org/10.1016/j.quascirev.2015.02.006.

Ogrinc, N., Lojen, S., and Faganeli, J., 2002, A mass balance of carbon stable isotopes in an organic-rich methane-producing lacustrine sediment (Lake Bled, Slovenia): Global and Planetary Change, v. 33, p. 57-72, https://doi.org/10.1016/s0921-8181(02)00061-9.

Ohmoto, H., Watanabe, Y., and Kumazawa, K., 2004, Evidence from massive siderite beds for a $\mathrm{CO}_{2}$-rich atmosphere before 1.8 billion years ago: Nature, v. 429, p. 395-399, https://doi.org/10.1038/nature02573.

Ordoñez, L. et al., 2019, Empowering conventional Rock-Eval pyrolysis for organic matter characterization of the siderite-rich sediments of Lake Towuti (Indonesia) using End-Member Analysis: Organic Geochemistry, v. 134, p. 32-44, https://doi.org/10.1016/j.orggeochem.2019.05.002.

Papineau, D., She, Z., and Dodd, M.S., 2017, Chemically-oscillating reactions during the diagenetic oxidation of organic matter and in the formation of granules in late Palaeoproterozoic chert from Lake Superior: Chemical Geology, v. 470, p. 33-54, http://dx.doi.org/10.1016/j.chemgeo.2017.08.021.

Parkhurst, D.L., and Appelo, C.A.J., 2013, Description of input and examples for PHREEQC version 3: a computer program for speciation, batch-reaction, one-dimensional transport, and inverse geochemical calculations: Techniques and Methods 6, A43, https://doi.org/10.3133/tm6a43.

Penger, J., Conrad, R., and Blaser, M., 2012, Stable carbon isotope fractionation by methylotrophic methanogenic Archaea: Applied and Environmental Microbiology, v. 78, p. 7596-7602, https://doi.org/10.1128/!AEM.01773-12. 
1194

1195

1196

1197

1198

1199

1200

1201

1202

1203

1204

1205

1206

1207

1208

1209

1210

1211

1212

1213

1214

1215

1216

1217

1218

1219

1220

1221

1222

1223

1224

1225

1226

1227

Planavsky, N., Rouxel, O.J., Bekker, A., Hofmann, A., Little, C.T.S., and Lyons, T.W., 2012, Iron isotope composition of some Archean and Proterozoic iron formations: Geochimica et Cosmochimica Acta, v. 80, p. 158-169, https://doi.org/10.1016/j.gca.2011.12.001.

Planavsky, N.J., and Busigny, V., 2017, Stable Iron Isotopes: Encyclopedia of Earth Sciences Series, p. 1-6, https://doi.org/10.1007/978-3-319-39193-9_267-1.

Planavsky, N.J., Reinhard, C.T., Isson, T.T., Ozaki, K., and Crockford, P.W., 2020, Large mass-independent oxygen isotope fractionations in Mid-Proterozoic sediments: Evidence for a low-oxygen atmosphere?: Astrobiology, v. 20, p. 628-636, https://doi.org/10.1089/ast.2019.2060.

Pohlman, J.W., Kaneko, M., Heuer, V.B., Coffin, R.B., and Whiticar, M., 2009, Methane sources and production in the northern Cascadia margin gas hydrate system: Earth and Planetary Science Letters, V. 287, p. 504-512, https://doi.org/10.1016/j.eps1.2009.08.037.

Posth, N.R., Canfield, D.E., and Kappler, A., 2014, Biogenic Fe(III) minerals: From formation to diagenesis and preservation in the rock record: Earth-Science Reviews, v. 135, p. 103-121, https://doi.org/10.1016/j.earscirev.2014.03.012.

Poulton, S.W., and Canfield, D.E., 2005, Development of a sequential extraction procedure for iron: implications for iron partitioning in continentally derived particulates: Chemical Geology, v. 214, p. 209-221, https://doi.org/10.1016/j.chemgeo.2004.09.003.

Poulton, S.W., and Canfield, D.E., 2011, Ferruginous Conditions: A Dominant Feature of the Ocean through Earth's History: Elements, v. 7, p. 107-112, https://doi.org/10.2113/gselements.7.2.107.

Poulton, S.W., Fralick, P.W., and Canfield, D.E., 2004, The transition to a sulphidic ocean 1.84 billion years ago: Nature, v. 431, p. 173-177, https://doi.org/10.1038/nature02912.

Pufahl, P.K., Pirajno, F., and Hiatt E.E., 2013, Riverine mixing and fluvial iron formation: A new type of Precambrian biochemical sediment: Geology, v. 41, p. 1235-1238, https://doi.org/10.1130/G34812.1.

Raiswell, R., Reinhard, C.T., Derkowski, A., Owens, J., Bottrell, S.H., Anbar, A.D., and Lyons, T.W., 2011, Formation of syngenetic and early diagenetic iron minerals in the late Archean Mt. McRae Shale, Hamersley Basin, Australia: New insights on the patterns, controls and paleoenvironmental implications of authigenic mineral formation: Geochimica et Cosmochimica Acta, v. 75, p. 10721087, https://doi.org/10.1016/j.gca.2010.11.013.

Reinhard, C.T., and Planavsky, N.J., 2011: Mineralogical constraints on Precambrian $\rho_{C} \mathrm{O}_{2}$ : Nature, v. 474, E1, https://doi.org/10.1038/nature09959.

Rosenbaum, J., and Sheppard, S.M.F., 1986, An isotopic study of siderites, dolomites and ankerites at high temperatures: Geochimica et Cosmochimica Acta, v. 50, p. 1147-1150, https://doi.org/10.1016/j.gca.2010.11.013.

Rosing, M.T., Bird, D.K., Sleep, N.H., and Bjerrum, C.J., 2010, No climate paradox under the faint early 
Sun: Nature, v. 464, p. 744-747, https://doi.org/10.1038/nature08955.

Russell, J.M., Vogel, H., Konecky, B.L., Bijaksana, S., Huang, Y., Melles, M., Wattrus, N., Costa, K., and King, J.K., 2014, Glacial forcing of central Indonesian hydroclimate since 60,000 y B.P.: Proceedings of the National Academy of Sciences of the United States of America, v. 111, p. 51005105, https://doi.org/10.1073/pnas.1402373111.

Russell, J.M. et al., 2020, The late quaternary tectonic, biogeochemical, and environmental evolution of ferruginous Lake Towuti, Indonesia: Palaeogeography, Palaeoclimatology, Palaeoecology, v. 556, e109905, https://doi.org/10.1016/j.palaeo.2020.109905.

Russell, J.M. et al., 2016, The Towuti Drilling Project: paleoenvironments, biological evolution, and geomicrobiology of a tropical Pacific lake: Scientific Drilling, v. 21, p. 12, https://doi.org/10.5194/sd-21-29-2016.

Saltzman, M.R., Thomas, E., 2012, Carbon isotope stratigraphy, in Gradstein, F.M., Ogg, J.G., Schmitz, M.D., and Ogg, G.M., eds.,The Geologic Time Scale, Elsevier, Ch. 11, p. 207-232, https://doi.org/10.1016/B978-0-444-59425.00011-1.

Sauterey, B., Charnay, B., Affholder, A., Mazevel, S., and Ferrière R., 2020, Co-evolution of primitive methane-cycling ecosystems and early Earth's atmosphere and climate: Nature Communications, v. 11, e2705, https://doi.org/10.1038/s41467-020-16374-7.

Schoenberg, R., and von Blanckenburg, F., 2005, An assessment of the accuracy of stable Fe isotope ratio measurements on samples with organic and inorganic matrices by high-resolution multicollector ICPMS: International Journal of Mass Spectrometry, v. 242, p. 257-272, https://doi.org/10.1016/j.ijms.2004.11.025.

Scholz, F., Hensen, C., Noffke, A., Rohde, A., Liebetrau, V., and Wallmann K., 2011, Early diagenesis of redox-sensitive trace metals in the Peru upwelling area-response to ENSO-related oxygen fluctuations in the water column: Geochimica et Cosmochimica Acta, v. 75, p. 7257-7276, https://doi.org/10.1016/j.gca.2011.08.007.

Scholz, F., Severmann, S., McManus, J., Noffke, A., Lomnitz, U., and Hensen, C., 2014, On the isotope composition of reactive iron in marine sediments: Redox shuttle versus early diagenesis: Chemical Geology, v. 389, p. 48-59, https://doi.org/10.1016/j.chemgeo.2014.09.009.

Severmann, S., Johnson, C.M., Beard, B.L., and McManus, J., 2006, The effect of early diagenesis on the Fe isotope compositions of porewaters and authigenic minerals in continental margin sediments: Geochimica et Cosmochimica Acta, v. 70, p. 2006-2022, https://doi.org/10.1016/j.gca.2006.01.007. Severmann, S., Lyons, T.W., Anbar, A., McManus, J., and Gordon, G., 2008, Modern iron isotope perspective on the benthic iron shuttle and the redox evolution of ancient oceans: Geology, v. 36, p. 487, https://doi.org/10.1130/g24670a.1. 
1262

1263

1264

1265

1266

1267

1268

1269

1270

1271

1272

1273

1274

1275

1276

1277

1278

1279

1280

1281

1282

1283

1284

1285

1286

1287

1288

1289

1290

1291

1292

1293

1294

1295

Sheppard, R.Y., Milliken, R.E., Russell, J.M., Sklute, E.C., Darby Dyar, M., Vogel, H., Melles, M., Bijaksana, Hasberg, A.K.M., and Morlock, M.A., 2019, Iron mineralogy and sediment color in a 100 $\mathrm{m}$ drill core from Lake Towuti, Indonesia reflect catchment and diagenetic conditions: Geochemistry, Geophysics, Geosystems, v. 22, e2020GC009582, https://doi.org/10.1029/2020GC009582.

Sheppard, R.Y., Milliken, R.E., Russell, J.M., Darby Dyar, M., Sklute, E.C., Vogel, H., Melles, M., Bijaksana, S., Morlock, M.A., and Hasberg, A.K.M., 2019, Characterization of Iron in Lake Towuti sediment: Chemical Geology, v. 512, p. 11-30, https://doi.org/10.1016/j.chemgeo.2019.02.029.

Silveira, M.L., Alleoni, L.R.F., O'Connor, G.A., and Chang, C.A., 2006, Heavy metal sequential extraction methods - A modification for tropical soils: Chemosphere, v. 64, p. 1929-1938, https://doi.org/10.1016/j.chemosphere.2006.01.018.

Staubwasser, M., von Blanckenburg, F., and Schoenberg, R., 2006, Iron isotopes in the early marine diagenetic iron cycle: Geology, v. 34, p. 629, https://doi.org/10.1130/g22647.1.

Stelbrink, B., Stöger, I., Hadiaty, R.K., Schliewen, U.K., and Herder, F., 2014, Age estimates for an adaptive lake fish radiation, its mitochondrial introgression, and an unexpected sister group: Sailfin Silversides of the Malili Lakes System in Sulawesi: BMC Evolutionary Biology, v. 14, p. 14-94, https://doi.org/10.1186/1471-2148-14-94.

Stookey, L.L., 1970, Ferrozine - a new spectrophotometric reagent for iron: Analytical Chemistry, v.42, p. 779-781, https://doi.org/10.1021/ac60289a016.

Swanner, E.D., Lambrecht, N., Wittkop, C., Harding, C., Katsev, S., Torgeson, J., and Poulton, S.W., 2020, The biogeochemistry of ferruginous lakes and past ferruginous oceans: Earth-Science Reviews, v. 211, e103430, https://doi.org/10.1016/j.earscirev.2020.103430.

Swart, P.K., Burns, S.J., and Leder, J.J., 1991, Fractionation of the stable isotopes of oxygen and carbon in carbon dioxide during the reaction of calcite with phosphoric acid as a function of temperature and technique: Chemical Geology: Isotope Geoscience Section, v. 86, p. 89-96, https://doi.org/10.1016/0168-9622(91)90055-2.

Tamuntuan, G., Bijaksana, S., King, J., Russell, J., Fauzi, U., Maryunani, K., Aufa, N., and Safiuddin, L.O., 2015, Variation of magnetic properties in sediments from Lake Towuti, Indoensia, and its paleoclimatic significance: Palaeogeography, Palaeoclimatology, Palaeoecology, v. 420, p. 163-172, https://doi.org/10.1016/j.palaeo.2014.12.008.

Tang, D., Shi, X., Jiang, G., Wu, T., Ma, J., and Zhou, X., 2018, Stratiform siderites from the Mesoproterozoic Xiamaling Formation in North China: Genesis and environmental implications: Geochimica et Cosmochimica Acta, v. 58, p. 1-15, https://doi.org/10.1016/j.gr.2018.01.013.

Tang, D., Ma, J., Shi, X., Lechte, M., and Zhou, X., 2020, The formation of marine red beds and iron cycling on the Mesoproterozoic North China Platform: American Mineralogist, v. 105, p. 1412-1423, 
1297

1298

1299

1300

1301

1302

1303

1304

1305

1306

1307

1308

1309

1310

1311

1312

1313

1314

1315

1316

1317

1318

1319

1320

1321

1322

1323

1324

1325

1326

1327

1328

1329

Tangalos, G.E., Beard, B.L., Johnson, C.M., Alpers, C.N., Shelobolina, E.S., Xu, H., Konishi, H., and Roden, E.E., 2010, Microbial production of isotopically light iron(II) in a modern chemically precipitated sediment and implications for isotopic variations in ancient rocks: Geobiology, v. 8, p. 197-208, https://doi.org/10.1111/j.1472-4669.2010.00237.x.

Taylor, W.E.G., 2005, Sedimentary Rocks | Siderite and Ironstones, in Selley, R.C., Cocks, L.R.M., and Plimer, I.R., eds., Encyclopedia of Geology, Elsevier, Ch. 11, p. 97-107, https://doi.org/10.1016/B012-369396-9/00314-2.

Teranes, J.L., McKenzie, J.A., Bernasconi, S.M., Lotter, A.F., and Sturm, M., 1999, A study of oxygen isotopic fractionation during bio-induced calcite precipitation in eutrophic Baldeggersee, Switzerland: Geochimica et Cosmochimica Acta, v. 63, p. 1981-1989, https://doi.org/10.1016/s00167037(99)00049-6.

Tierney, J.E., Oppo, D.W., LeGrande, A.N., Huang, Y., Rosenthal, Y., and Linsley, B.K., 2012, The influence of Indian Ocean atmospheric circulation on Warm Pool hydroclimate during the Holocene epoch: Journal of Geophysical research, v. 117, D19108, https://doi.org/10.1029/2012JDO018060.

Tosca, N.J., Jiang, C.Z., Rasmussen, B., and Muhling, J., 2019: Products of the iron cycle on the early Earth: Free Radical Biology and Medicine, v. 140, p. 138-153, https://doi.org/10.1016/j.freeraddbiomed.2019.05.005.

Ulfers, A., Hesse, K., Russell, J.M., Vogel, H., Wonik, T., 2021. Cyclostratigraphy and paleoenvironmental influence from downhole logging of sediments in tropical Lake Towuti, Indonesia: Journal of Paleolimnology, v. 65, p. 377-392, https://doi.org/10.1007/s10933-020-00171-9.

Van Dijk, J., Fernandez, A., Müller, I., Lever, M., and Bernasconi, S., 2018, Oxygen isotope fractionation in the siderite-water system between 8.5 and $62^{\circ} \mathrm{C}$ : Geochimica et Cosmochimica Acta, v. 220, p. $535-$ 551, https://doi.org/10.1016/j.gca.2017.10.009.

Van Dijk, J., Fernandez, A., Bernasconi, S.M., Caves Rugenstein, J.K., Passey, S.R. and White, T., 2020, Spatial pattern of super-greenhouse warmth controlled by elevated specific humidity: Nature geoscience, v. 13, p. 739-744, https://doi.org/10.1038/s41561-020-00648-2.

Viollier, E., Inglett, P.W., Hunter, K., Roychoudhury, A.N., and Van Cappellen, P., 2000, The ferrozine method revisited: $\mathrm{Fe}(\mathrm{II}) / \mathrm{Fe}(\mathrm{III})$ determination in natural waters: Applied geochemistry: journal of the International Association of Geochemistry and Cosmochemistry, v. 15, p. 785-790, https://doi.org/10.1016/S0883-2927(99)00097-9.

Vogel, H., Russell, J.M., Cahyarini, S.Y., and Bijaksana, S., 2015, Depositional modes and lake-level variability at Lake Towuti, Indonesia, during the past 29 kyr BP: Journal of Paleolimnology, v. 54, p. 359-377, https://doi.org/10.1007/s10933-015-9857-z. 
1330

1331

1332

1333

1334

1335

1336

1337

1338

1339

1340

1341

1342

1343

1344

1345

1346

1347

1348

1349

1350

1351

1352

1353

1354

1355

1356

1357

1358

1359

1360

1361

1362

1363

von Blanckenburg, F., Mamberti, M., Schoenberg, R., Kamber, B.S., and Webb, G.E., 2008, The iron isotope composition of microbial carbonate: Chemical Geology, v. 249, p. 113-128, https://doi.org/10.1016/j.chemgeo.2007.12.001.

Vuillemin, A., Ariztegui, D., Vasconcelos, C., and the PASADO Scientific Drilling Party, 2010: Establishing sampling procedures in lake cores for subsurface biosphere studies: Assessing in situ microbial activity: Scientific Drilling, v.10, p. 35-39, https://doi.org/10.2204/iodp.sd.10.04.2010.

Vuillemin, A., Ariztegui, D., De Coninck, A.S., Lücke, A., Mayr, C., Schubert, C.J., and the PASADO Science Team, 2013, Origin and significance of diagenetic concretions in sediments of Laguna Potrok Aike, southern Argentina: Journal of Paleolimnology, v. 50, p. 275-291, https://doi.org/10.1007/s10933-013-9723-9.

Vuillemin, A., Ariztegui, D., Nobbe, G., Schubert, C.J., and the PASADO Science Team, 2014a, Influence of methanogenic populations in Holocene lacustrine sediments revealed by clone libraries and fatty acid biogeochemistry: Geomicrobiology Journal, v. 31, p. 285-298, https://doi.org/10.1080/01490451.2013.824050.

Vuillemin, A., Ariztegui, D., Lücke, A., Mayr, C., and the PASADO Science Team, 2014b, Paleoenvironmental conditions define current sustainability of microbial populations in Laguna Potrok Aike sediments, Argentina: Aquatic Sciences, v.76, p. 101-114, https://doi.org/10.1007/s00027-013-0317-4.

Vuillemin, A., Friese, A., Alawi, M., Henny, C., Nomosatryo, S., Wagner, D., Crowe, S.A., and Kallmeyer, J., 2016, Geomicrobiological Features of Ferruginous Sediments from Lake Towuti, Indonesia: Frontiers in Microbiology, v. 7, e1007, https://doi.org/10.3389/fmicb.2016.01007.

Vuillemin, A., Horn, F., Alawi, M., Henny, C., Wagner, D., Crowe, S.A., and Kallmeyer, J., 2017, Preservation and significance of extracellular DNA in ferruginous sediments from Lake Towuti, Indonesia: Frontiers in Microbiology, v. 8, e1440, https://doi.org/10.3389/fmicb.2017.01440.

Vuillemin, A., Horn, F., Friese, A., Winkel, M., Alawi, M., Wagner, D., Henny, C., Orsi, W.D., Crowe, S.A., and Kallmeyer, J., 2018, Metabolic potential of microbial communities from ferruginous sediments: Environmental Microbiology, v. 20, p. 4297-4313, https://doi.org/10.1111/14622920.14343.

Vuillemin, A. et al., 2019a, Formation of diagenetic siderite in modern ferruginous sediments: Geology, v. 47, p. 540-544, https://doi.org/10.1130/G46100.1.

Vuillemin A. et al., 2019b, Pore water geochemistry and bulk sediment measurements of downcore profiles from site TDP-1A of the ICDP Towuti Drilling Project, Lake Towuti, Indonesia: https://doi.pangaea.de/10.1594/PANGAEA.908080.

Vuillemin, A. et al., 2020, Vivianite formation in ferruginous sediments from Lake Towuti, Indonesia: 
Biogeosciences, v. 17, p. 1955-1973, https://doi.org/10.5194/bg-17-1955-2020.

Vuillemin et al., 2021, Siderite C-O-Fe isotope compositions, pore water geochemistry and bulk sediment parameters from the 100-m-long core TDP-1A of the ICDP Towuti Drilling Project, Lake Towuti, Indonesia: https://doi.pangaea.de/10.1594/PANGAEA.934401.

Watkins, J.M., Nielsen, L.C., Ryerson, F.J., and DePaolo, D.J., 2013, The influence of kinetics on the oxygen isotope composition of calcium carbonate: Earth and Planetary Science Letters, v. 375, p. 349-360, https://doi.org/10.1016/j.eps1.2013.05.054.

Watkinson, I.M., and Hall, R., 2017: Fault systems of the eastern Indonesian triple junction: evaluation of Quaternary activity and implications for seismic hazards, in: Cummings, P.R., and Meilano, I., eds., Geohazards in Indonesia: Earth Science for Disaster Risk Reduction: Geological Society, London, Special Publications 441, p. 71-120, https://doi.org/10.1144/SP441.8

Wicaksono, S.A., Russell, J.M., and Bijaksana, S., 2015, Compound-specific carbon isotope records of vegetation and hydrologic change in central Sulawesi, Indonesia, since 53,000 yr BP: Palaeogeography, Palaeoclimatology, Palaeoecology, v. 430, p. 47-56, https://doi.org/10.1016/j.palaeo.2015.04.016.

Wiesli, R.A., Beard, B.L., and Johnson, C.M., 2004, Experimental determination of Fe isotope fractionation between aqueous $\mathrm{Fe}(\mathrm{II})$, siderite and "green rust" in abiotic systems: Chemical Geology, v. 211, p. 343-362, https://doi.org/10.1016/j.chemgeo.2004.07.002.

Winter, B.L., and Knauth, P.L., 1992, Stable isotope geochemistry of cherts and carbonates from the $2.0 \mathrm{Ga}$ Gunflint Iron Formation: Implications for the depositional setting, and the effects of diagenesis and metamorphism: Precambrian Research, v. 59, p. 283-313, https://doi.org/10.1016/03019268(92)90061-R.

Wittkop, C., Teranes, J., Lubenow, B., and Dean, W.E., 2014, Carbon- and oxygen-stable isotopic signatures of methanogenesis, temperature, and water column stratification in Holocene siderite varves: Chemical Geology, v. 389, p. 153-166, https://doi.org/10.1016/j.chemgeo.2014.09.016.

Wu, B., Amelung, W., Xing, Y., Bol, B., and Berns, A.E., 2019, Iron cycling and isotope fractionation in terrestrial ecosystems: Earth-Science Reviews, v. 190, p. 323-352, https://doi.org/10.1016/j.earscirev.2018.12.012.

Zhang, C.L., Horita, J., Cole, D.R., Zhou, J., Lovley, D.R., and Phelps, T.J., 2001, Temperature-dependent oxygen and carbon isotope fractionations of biogenic siderite: Geochimica et Cosmochimica Acta, v. 65, p. 2257-2271, https://doi.org/10.1016/S0016-7037(01)00596-8. 

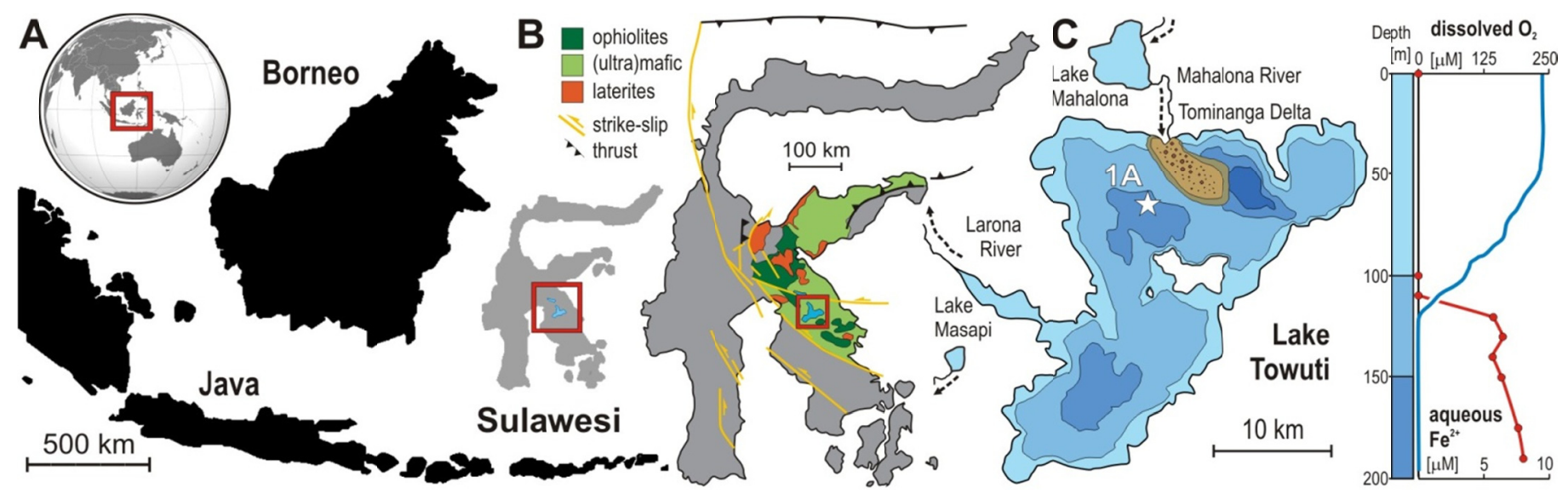

1399 Figure 1. Site description of Lake Towuti. (A) World map displaying the location of Sulawesi Island (red square) with close-up on the Indonesia archipelago and location of the Malili Lake System. (B) Map of Sulawesi illustrating the weathered ultramafic catchment of Lake Towuti. (C) Bathymetric map of Lake 1402 Towuti with position of drill site TDP-1A (156 m water depth), dissolved oxygen (after Vuillemin et al., 1403 2016) and ferrous iron concentrations (after Bauer et al., 2020) in the water column $[\mu \mathrm{M}]$. 


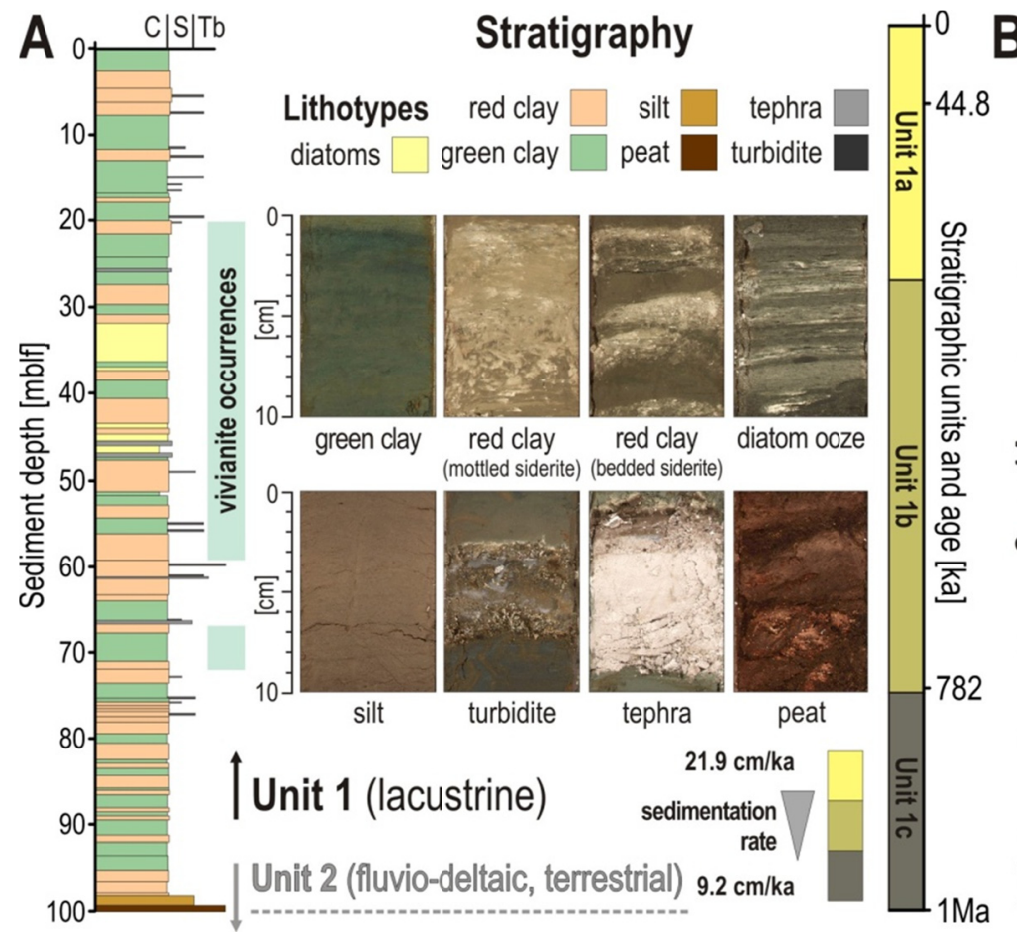

B

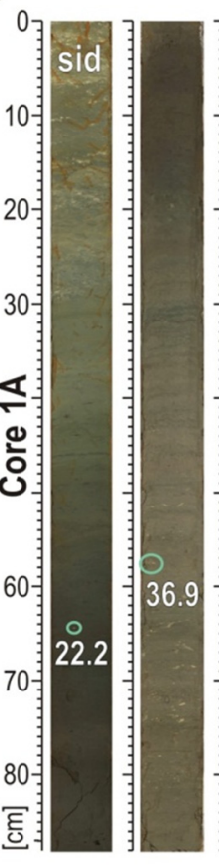

Vivianite occurrences

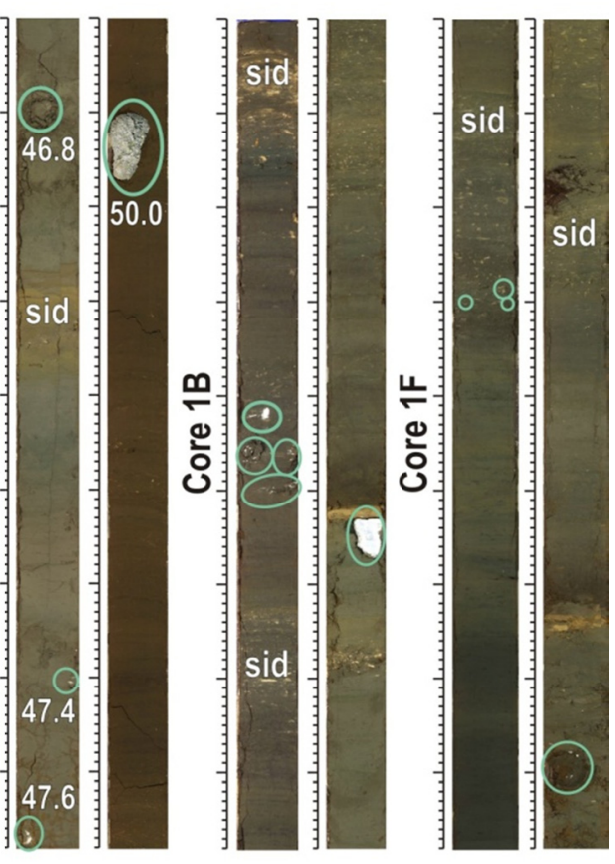

Figure 2. Composite lithostratigraphy together with the major lithotypes, and vivianite occurrences.

(A) Stratigraphy of site TDP-1A (Russell et al., 2016) and major lithotypes observed across the Unit 1 lacustrine sequence (after Russell et al., 2020), namely massive to bedded green clay, sideritic mottled and bedded red clay, bedded diatomaceous ooze, silt, turbiditic layer, rhyolitic to andesitic tephra, and bedded to woody peat (Unit 2 fluvio-deltaic, terrestrial lithotypes not shown). Sedimentation rates decrease drastically down core from $21.9 \mathrm{~cm} \mathrm{ka}^{-1}$ in Unit 1a to $9.2 \mathrm{~cm} \mathrm{ka}^{-1}$ in Unit 1c. (B) Core scanning images for sections in which vivianite was identified (after Vuillemin et al., 2020). Sediments display variations in colors from light brown to dark brown with grey-green transitions, presently interpreted as reflecting redox conditions at the water-sediment interface. In the record of core TDP-1A, vivianites are usually found in the darker layers. However, at site $1 \mathrm{~B}$ and $1 \mathrm{~F}$, vivianite crystals are also found close to siderite layers. 


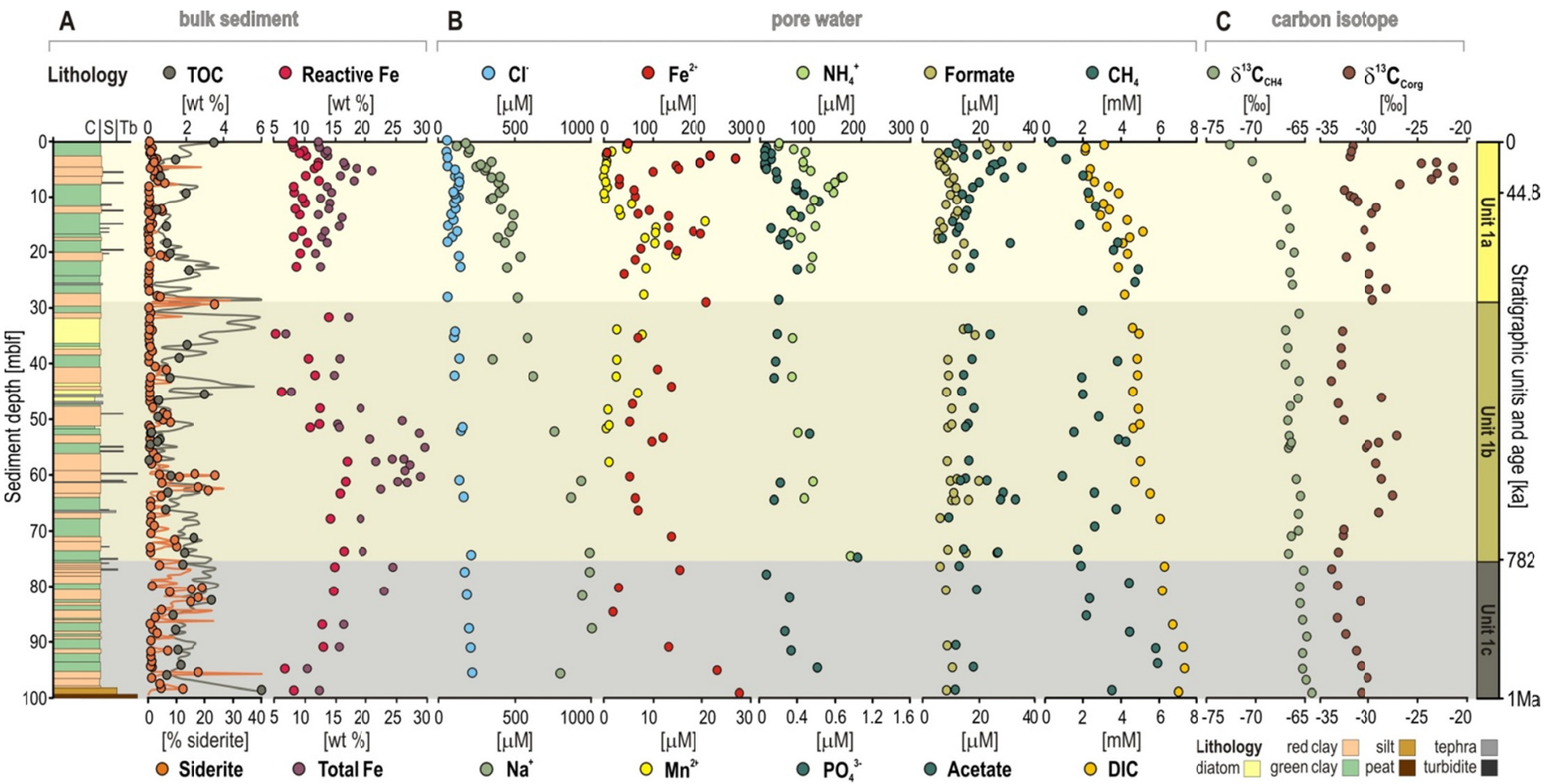

1419 Figure 3. Depth profiles for bulk sediment, pore water geochemistry and carbon isotopes. From left to right: (A) Stratigraphy of site TDP-1A (Russell et al., 2016); total organic carbon [\% TOC] and siderite [\% siderite] concentrations based on rock-eval analysis (circles; from Ordoňez et al., 2019) and coulometry

1422 (lines; Russell et al., 2020); reactive and total iron concentrations [weight \%] in bulk sediment; (B) $\mathrm{Cl}^{-}$and $1423 \mathrm{Na}^{+}$concentrations in pore water $[\mu \mathrm{M}] ; \mathrm{Fe}^{2+}$ and $\mathrm{Mn}^{2+}$ concentrations in pore water $[\mu \mathrm{M}]$; ammonium $1424\left(\mathrm{NH}_{4}{ }^{+}\right)$and phosphate $\left(\mathrm{PO}_{4}{ }^{3-}\right)$ concentrations in pore water $[\mu \mathrm{M}]$; formate and acetate concentrations in pore 1425 water $[\mu \mathrm{M}]$; methane and dissolved inorganic carbon (DIC) concentrations $[\mathrm{mM}]$; and $(\mathbf{C})$ the respective $1426 \delta{ }^{13} \mathrm{C}$ values for methane and bulk TOC relative to V-PDB [\%o]. Concentration profiles for reactive Fe, total $1427 \mathrm{Fe}$, pore water $\mathrm{Fe}^{2+}, \mathrm{Mn}^{2+}, \mathrm{PO}_{4}{ }^{3-}$ and DIC concentrations are modified after Vuillemin et al. $(2019,2020)$. 


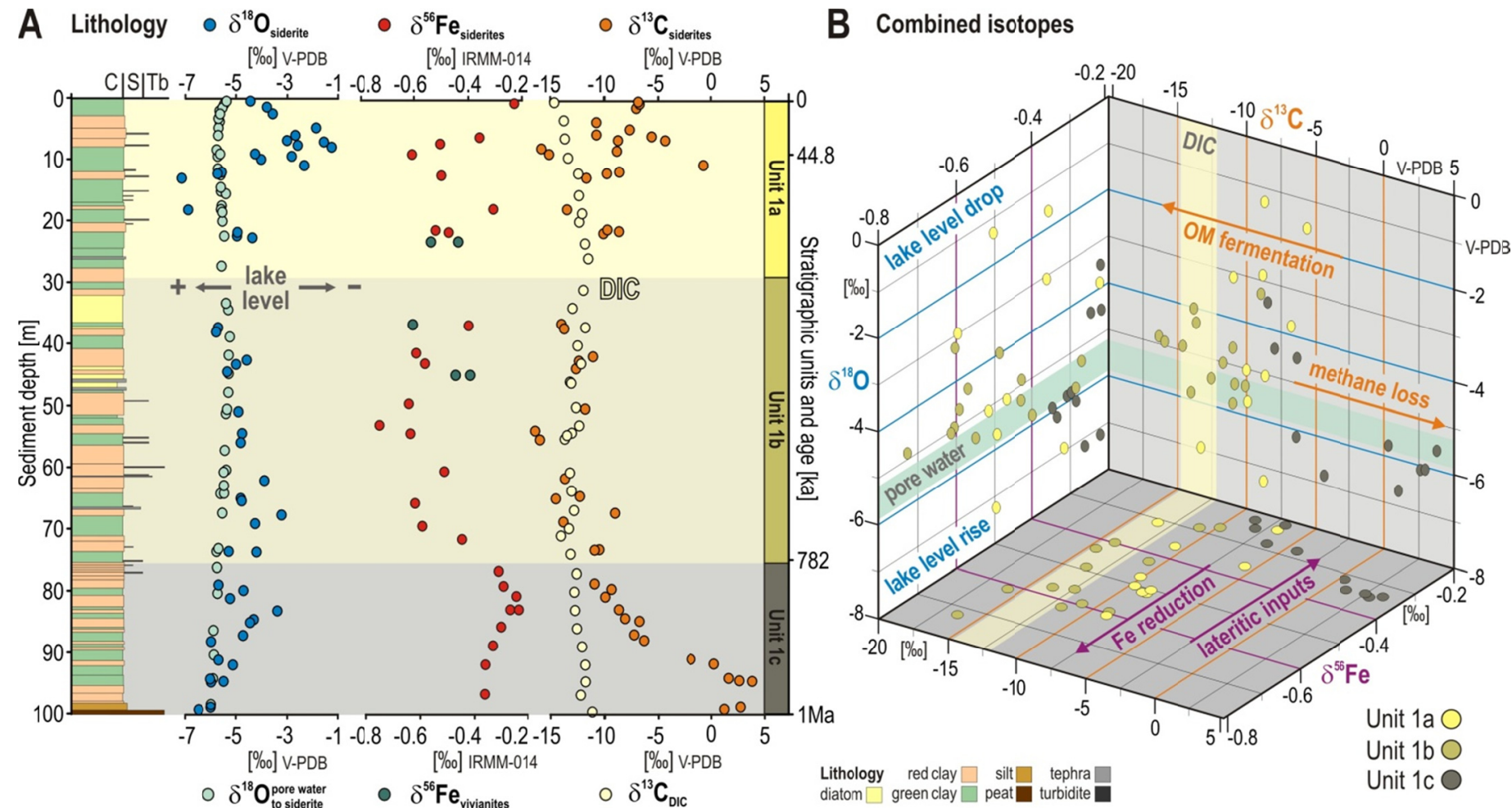

1431 Figure 4. Comparison between oxygen, iron and carbon isotope values in siderites. From left to right:

1432 (A) Stratigraphy of site TDP-1A (Russell et al., 2016); empirical $\delta^{18} \mathrm{O}$ values of siderites (dark blue) in parallel to those theoretically calculated from pore water to siderite (light green), both relative to V-PDB $1434[\%]$. The arrow indicates the higher evaporation-to-inflow ratio associated with the lake level drop during the Last Glacial Maximum; $\delta^{56} \mathrm{Fe}$ values measured on siderite (red) and vivianite (green) crystals relative to IRMM-014 [\%o]; $\delta^{13} \mathrm{C}$ values for siderite crystals (orange) and DIC (yellow) relative to V-PDB [\%o]. (B) Three dimensional plot combining the $\delta^{18} \mathrm{O}, \delta^{56} \mathrm{Fe}$ and $\delta^{13} \mathrm{C}$ isotope values of siderites, with indication of syn-depositional and post-depositional processes inferred to have set their final isotope signatures. 
1441

1442

1443

1444

1445

1446

1447

1448

1449

1450

1451

1452

1453

1454

1455

1456
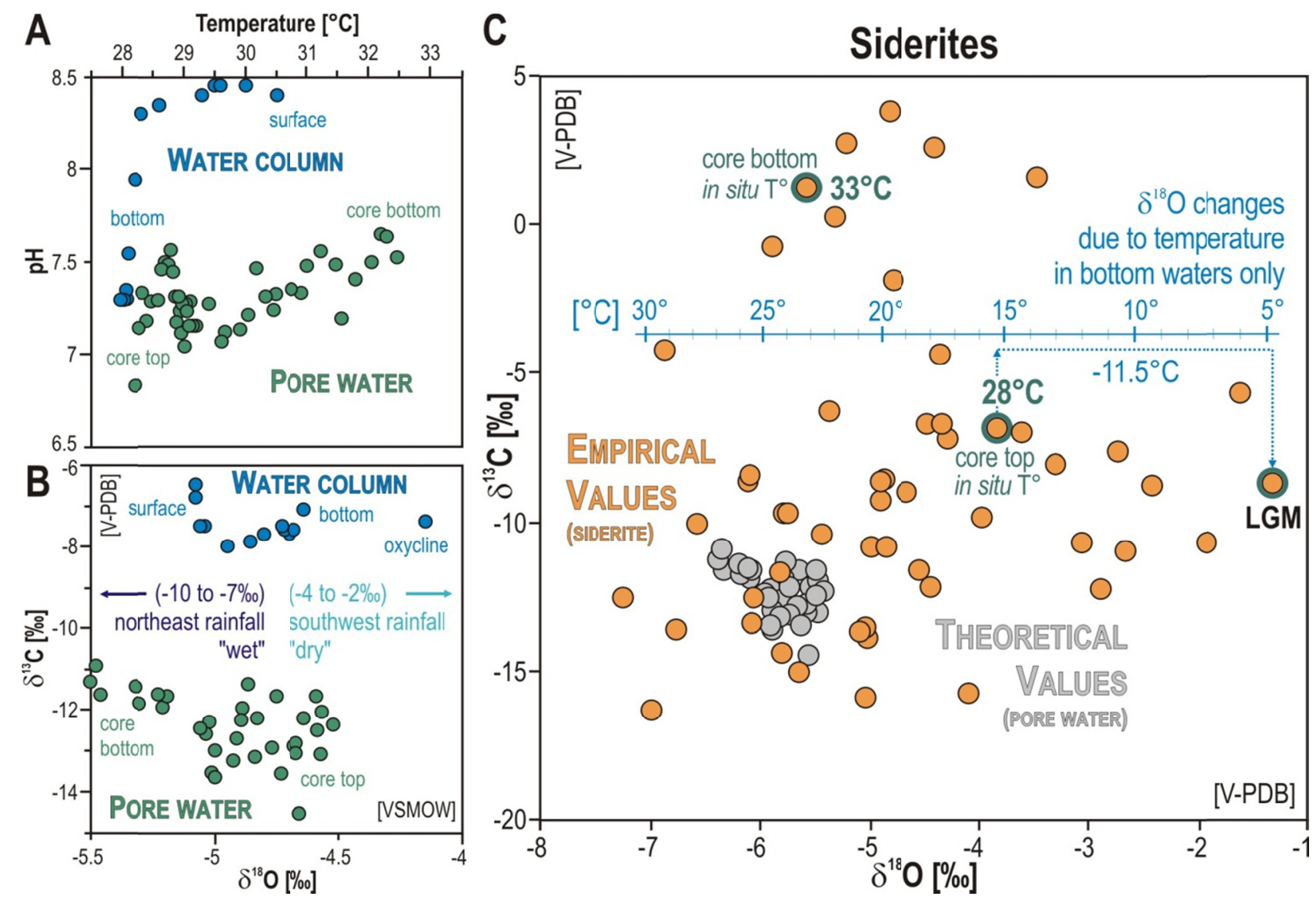

Siderites

Figure 5. Comparison between pH, temperature, oxygen and carbon isotopes for the water column, pore water and siderite crystals. (A) Temperature $\left[{ }^{\circ} \mathrm{C}\right]$ measured in the water column as temperature casts (Vuillemin et al., 2016) and in the sediment as borehole logging (Ulfers et al., 2021) versus pH measured on water column (Bauer et al., 2020) and pore water samples (Vuillemin et al., 2019a). (B) The $\delta^{18} \mathrm{O}$ and $\delta^{13} \mathrm{C}$ values measured on water column and pore water samples display some correlation with temperature and $\mathrm{pH}$, with slightly more positive $\delta^{18} \mathrm{O}$ and more negative $\delta^{13} \mathrm{C}$ values at lower temperatures and $\mathrm{pH}$, respectively. The $\delta^{13} \mathrm{C}$ values for Lake Towuti's water column were predicted from those measured in Lake Matano (after Kuntz et al., 2015). The $\delta^{18} \mathrm{O}$ values for seasonal precipitations (from Konecky et al., 2016) correspond with the northeast and southwest monsoons, high ("wet") and low ("dry") rainfall from

November to May and from June to October, respectively. (C) The $\delta^{18} \mathrm{O}$ and $\delta^{13} \mathrm{C}$ values plotted for siderites emphasize the broader scatter of empirical values (orange dots) measured on isolated crystals compared to the theoretical ones (grey dots) predicted from pore water. The range of temperatures (blue axis) assumes that the $\delta^{18} \mathrm{O}$ signal is attributed to temperature changes in bottom waters only (after van Dijk et al., 2018). This means that a temperature drop of $11.5^{\circ} \mathrm{C}$ is required to explain the heavier $\delta^{18} \mathrm{O}$ values measured in siderites from the Last Glacial Maximum (LGM) interval, equaling $16.5^{\circ} \mathrm{C}$ in bottom waters at that time. 

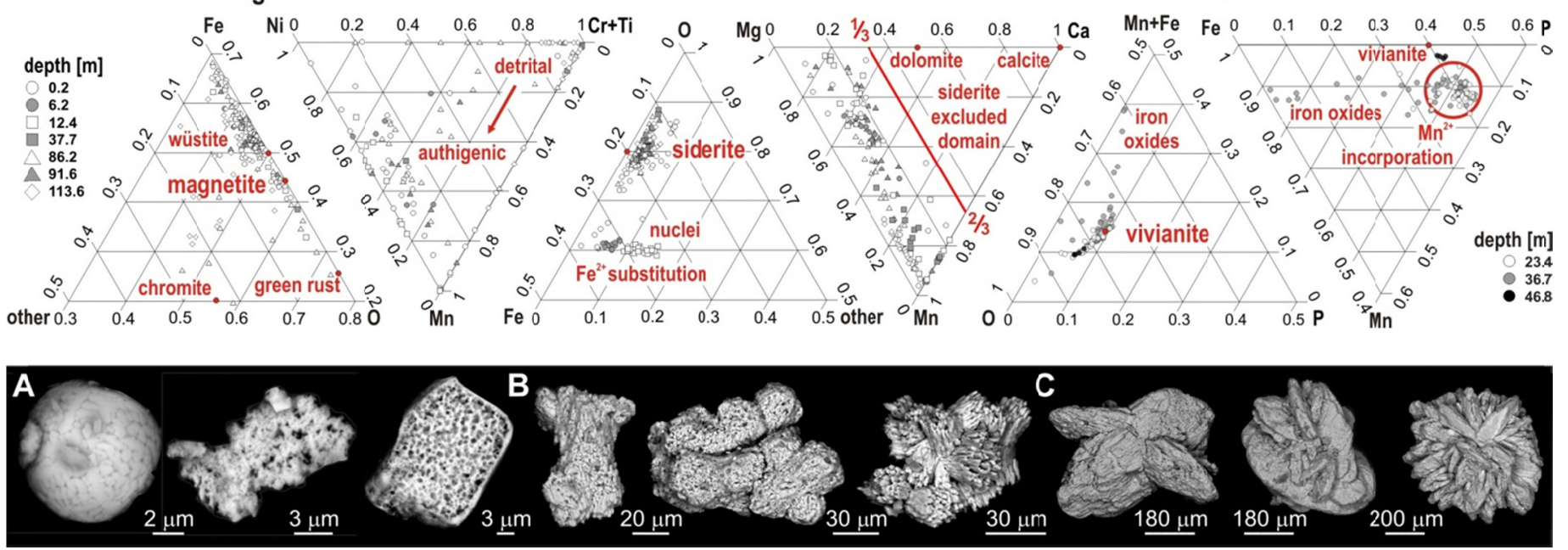

1459 Figure 6. Elemental EDS punctual analyses and SEM images of diagenetic phases. (A) magnetites

1460 displaying framboidal habitus, precipitation and dissolution features; (B) siderites illustrating continuous 1461 growth into twins and aggregates (after Vuillemin et al., 2019a); and (C) vivianites developing from a 1462 tabular habitus into rosette (after Vuillemin et al., 2020). Although trace elements (e.g. Ni, Mn, Ti, Cr) are 1463 common in magmatic magnetites (Supplementary Table S4), increased Mn and Ni contents potentially point 1464 to neoformation of magnetites in the water column (Bauer et al., 2020) and sediment (Vuillemin et al., 1465 2019a). In contrast, siderites and vivianites (Vuillemin et al., 2020) clearly form in the sediment and substitute $\mathrm{Mn}^{2+}$ for $\mathrm{Fe}^{2+}$ in their initial growth phase. Mn-Fe elemental zonations in siderites are visible in 1467 Supplementary Fig. S7. 


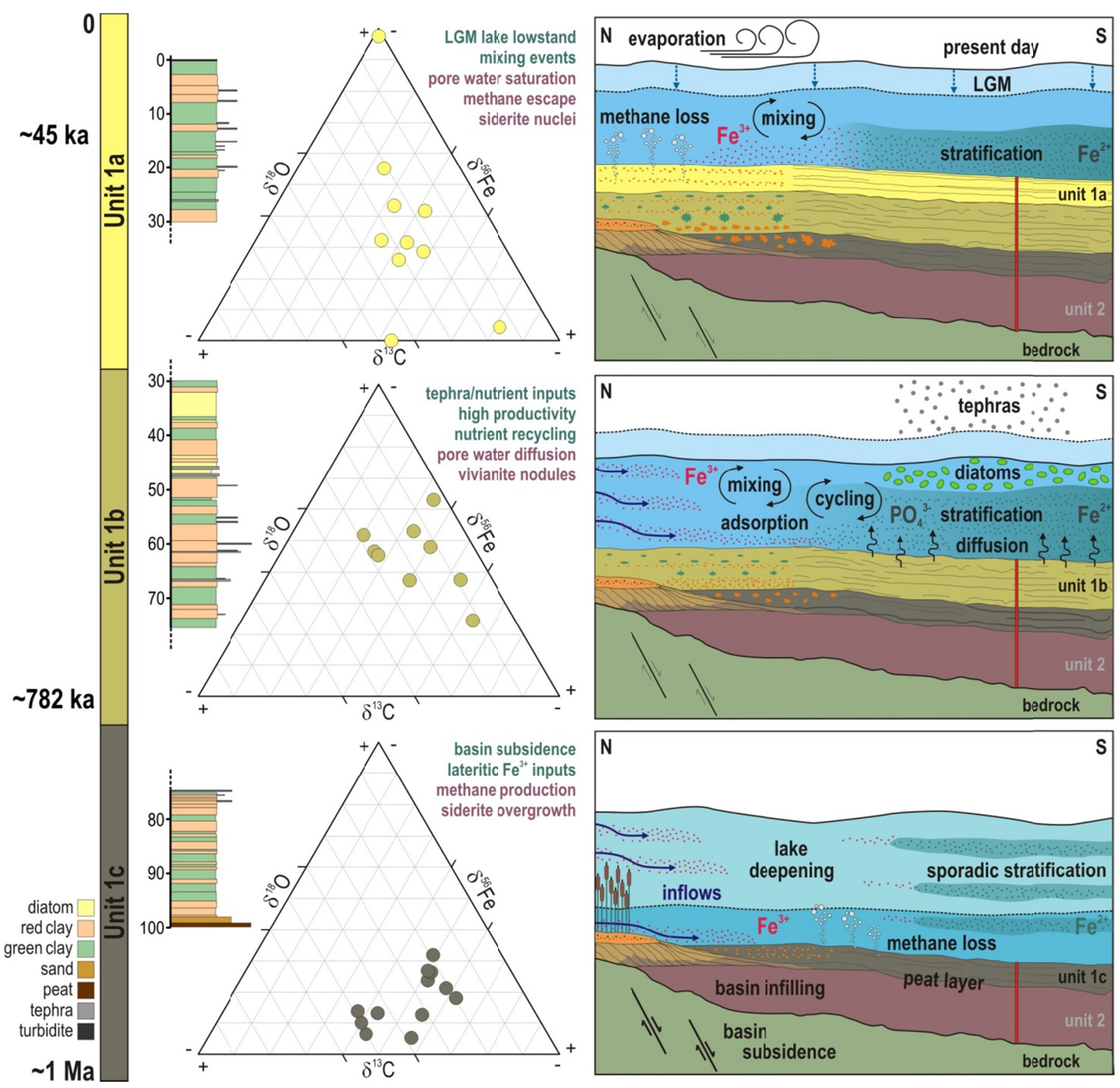

1470 Figure 7. Syn- and post-depositional processes and their resulting combined isotope signatures. From

1471 bottom to top, the three stratigraphic units defined along the $\sim 1$ Ma geological history of Lake Towuti

1472 (Russell et al., 2020) and their isotope signatures successively correspond to: (Unit 1c) initial basin

1473 subsidence and infilling with floods and river inflows $\left(\delta^{18} \mathrm{O}\right)$, partial reduction of detrital $\mathrm{Fe}$ inputs $\left(\delta^{56} \mathrm{Fe}\right)$,

1474 increased methane production and escape during OM remineralization at shallow burial $\left(\delta^{13} \mathrm{C}\right)$; (Unit 1b)

1475 steady hydrological conditions $\left(\delta^{18} \mathrm{O}\right)$, diffusion across the SWI and in-lake recycling $\left(\delta^{56} \mathrm{Fe}\right)$, vivianite

1476 formation with production of biogenic DIC in the sediment $\left(\delta^{13} \mathrm{C}\right)$; (Unit 1a) lake level fluctuations during

1477 the last glacial-interglacial transition $\left(\delta^{18} \mathrm{O}\right)$, mixing events followed by sediment Fe reduction and

1478 partitioning $\left(\delta^{56} \mathrm{Fe}\right)$, active $\mathrm{OM}$ fermentation processes and sporadic methane escape from the sediment

$1479\left(\delta^{13} \mathrm{C}\right)$. 
1480 Table 1. Modeled saturation indices based on $\mathbf{p H}$, alkalinity, pore water concentrations of major ions

1481 and borehole temperatures. Siderite appears to be over saturation throughout the sedimentary sequence,

1482 whereas vivianite remains at near-saturation with sediment depth. Pore water saturation with respect to

1483 vivianite is reached around 20 mblf (Vuillemin et al., 2020).

\begin{tabular}{|cc|cc|}
\hline \hline 5 m depth & \multicolumn{1}{c}{ Saturation } & 10 m depth & Saturation \\
\hline talc/serpentine & 1.43 & siderite & $\mathbf{1 . 0 0}$ \\
siderite & $\mathbf{1 . 2 9}$ & quartz & 0.71 \\
quartz & 0.71 & vivianite & $\mathbf{- 0 . 0 4}$ \\
vivianite & $\mathbf{- 0 . 4 5}$ & talc/serpentine & -0.31 \\
calcite & -0.68 & calcite & -0.83 \\
dolomite & -0.77 & aragonite & -0.97 \\
aragonite & -0.82 & dolomite & -1.27 \\
\hline
\end{tabular}

Supplementary Material: Supplementary Figures S1 to S9 and Supplementary Tables S1 to S5. 


\title{
Supplemental Material
}

\section{A one-million-year isotope record from siderites formed in modern ferruginous sediments.}

\author{
Aurèle Vuillemin*, Christoph Mayr, Jan A. Schuessler, André Friese, Kohen W. Bauer, Andreas Lücke, \\ Verena B. Heuer, Clemens Glombitza, Cynthia Henny, Friedhelm von Blanckenburg, James M. Russell, \\ Satria Bijaksana, Hendrik Vogel, Sean A. Crowe, and Jens Kallmeyer.
}

\section{Content:}

Supplementary Figure S1. Borehole temperatures with pore water alkalinity, pH, DIC and oxygen isotopes

Supplementary Figure S2. Treatment of bulk sediments and siderite for carbonate dissolution

Supplementary Figure S3. XRD spectra for siderite and vivianite extracts.

Supplementary Figure S4. Age model used for the calibration of the Unit 1 lacustrine sequence

Supplementary Figure S5. Temperature, $\mathrm{O}_{2}$ concentrations and oxygen isotopes in the water column

Supplementary Figure S6. SEM back-scatter images of magnetite extracts.

Supplementary Figure S7. TEM images and elemental mapping of siderite nuclei

Supplementary Figure S8. Scatter plots of siderite isotope compositions.

Supplementary Figure S9. Syn-depositional and post-depositional processes setting isotope signatures

Supplementary Table S1. Oxygen isotope fractionation factors between different phases and siderite.

Supplementary Table S2. Siderite oxygen isotope values calculated with different acid fractionation factors.

Supplementary Table S3. Results of iron isotopes for data quality control.

Supplementary Table S4. Results of EDS analyses on magnetic extracts and corresponding SEM images.

Supplementary Table S5. Results of EDS analyses on siderite samples and corresponding SEM images.

Supplementary Table S6. Results of EDS analyses on vivianite samples and corresponding SEM images. 


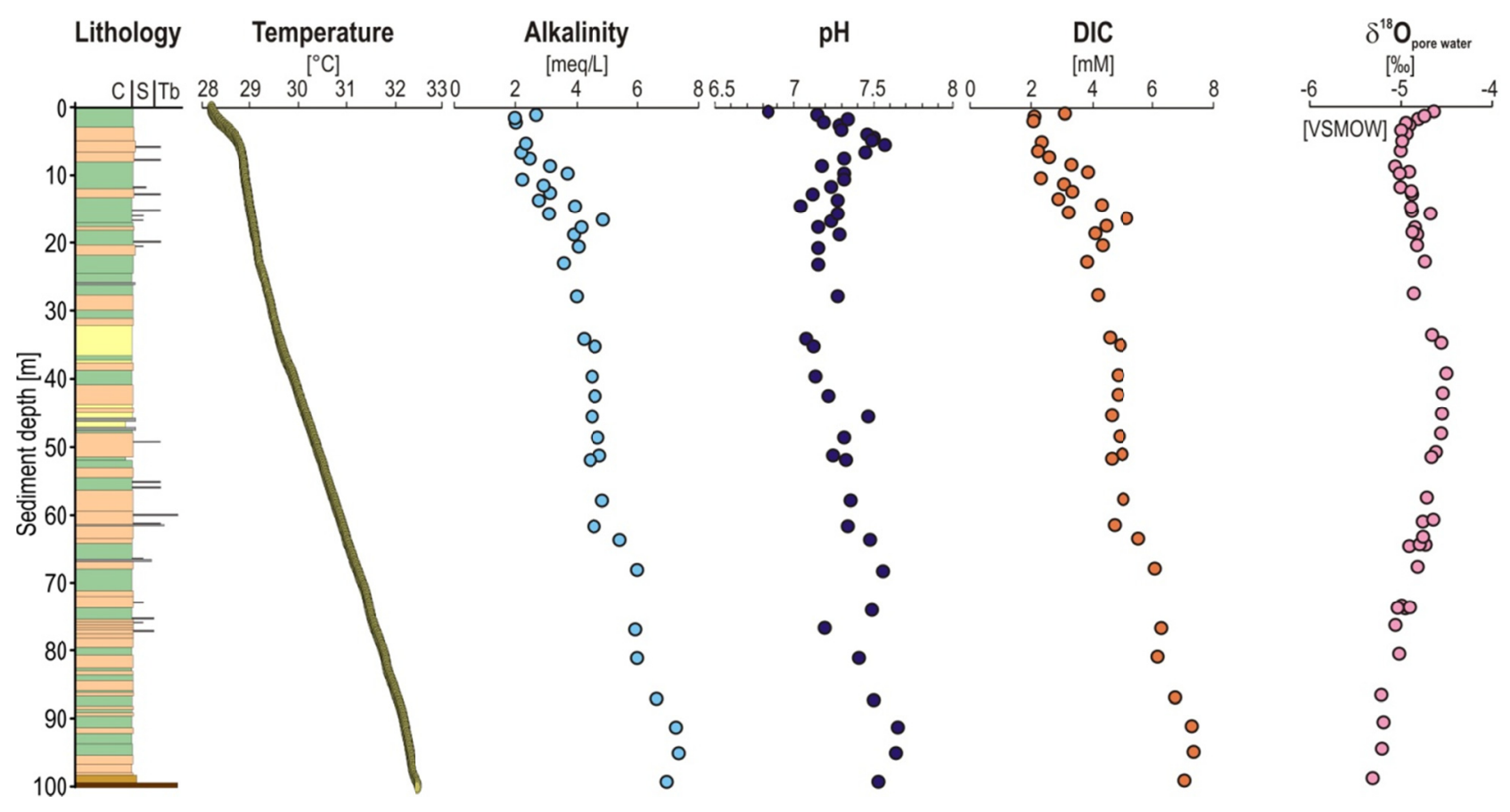

Supplementary Figure S1. Down core profiles for physicochemical parameters and pore water oxygen isotopes. From left to right: Borehole temperatures obtained on site via borehole logging, showing an overall increase in temperatures from $28^{\circ}$ to $33^{\circ} \mathrm{C}$ in the $100 \mathrm{~m}$ of Unit 1 at hole TDP-1B; alkalinity [meq $\times \mathrm{L}^{-1}$ ], and $\mathrm{pH}$ measured on pore water at hole TDP-1A; DIC calculated by solving the carbonate system based on the previous three profiles; oxygen isotopes versus VSMOW [\%o] in the pore water display little variations despite a temperature increase of $4^{\circ} \mathrm{C}$. 


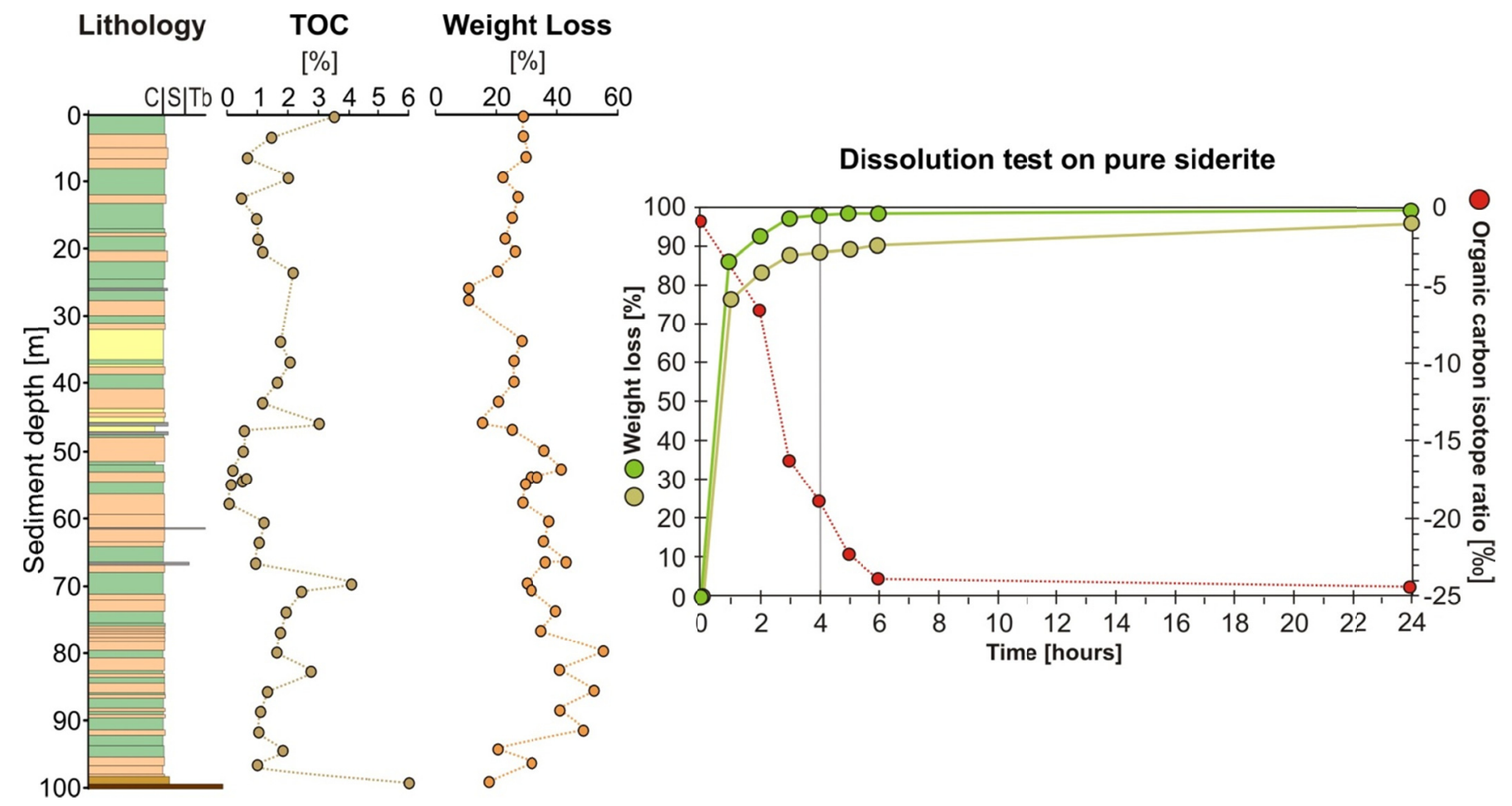

Supplementary Figure S2. Treatment of bulk sediments and siderite for carbonate dissolution. Bulk sediment samples were treated with $20 \mathrm{~mL}$ of $5 \% \mathrm{HCl}$ at $50^{\circ} \mathrm{C}$ for 24 hours to remove carbonates. This treatment was tested with $200 \mathrm{mg}$ of technical grade siderite to evaluate its dissolution over time. Results show that 85 to $95 \%$ of the siderite weight is dissolved after 2 hours. After 24 hours, $>95 \%$ of siderite is dissolved, ensuring accurate measurement of both total organic carbon content and $\delta^{13} \mathrm{C}_{\text {org }}$ composition on bulk sediment. 

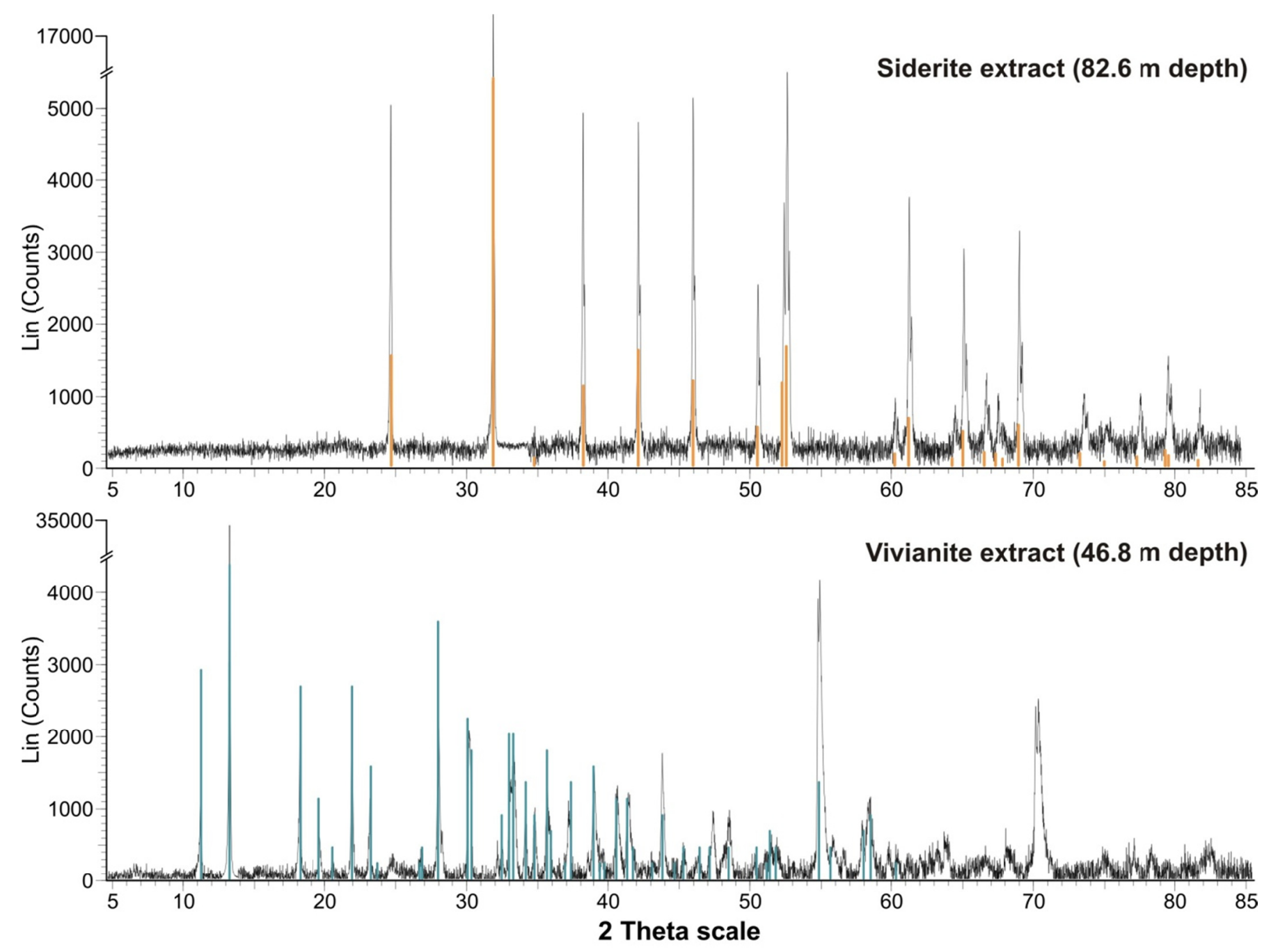

Siderite (01-080-0502) $\mathrm{Ca}_{0.1} \mathrm{Mg}_{0.33} \mathrm{Fe}_{0.57}\left(\mathrm{CO}_{3}\right) / \mathrm{Rhombohedral:} \mathrm{a}=4.704 / \mathrm{b}=4.704 / \mathrm{c}=15.460 / \alpha=90.00 / \beta=90.00 / \gamma=120.00$ Syn. vivianite (00-030-0662) $\mathrm{Fe}_{3}\left(\mathrm{PO}_{4}\right)_{2} \cdot 8 \mathrm{H}_{2} \mathrm{O} /$ Monoclinic: $\mathrm{a}=10.034 / \mathrm{b}=13.449 / \mathrm{c}=4.707 / \alpha=90.00 / \beta=102.65 / \gamma=90.00$

Supplementary Figure S3. XRD spectra for siderite and vivianite extracts. XRD spectra of pure siderite (top) and vivianite (bottom) extracts from 86.2 and $46.8 \mathrm{~m}$ depth (modified from Vuillemin et al., 2019a, 2020), respectively, with reference peaks of synthetic siderite (orange bars) and vivianite (blue bars). 


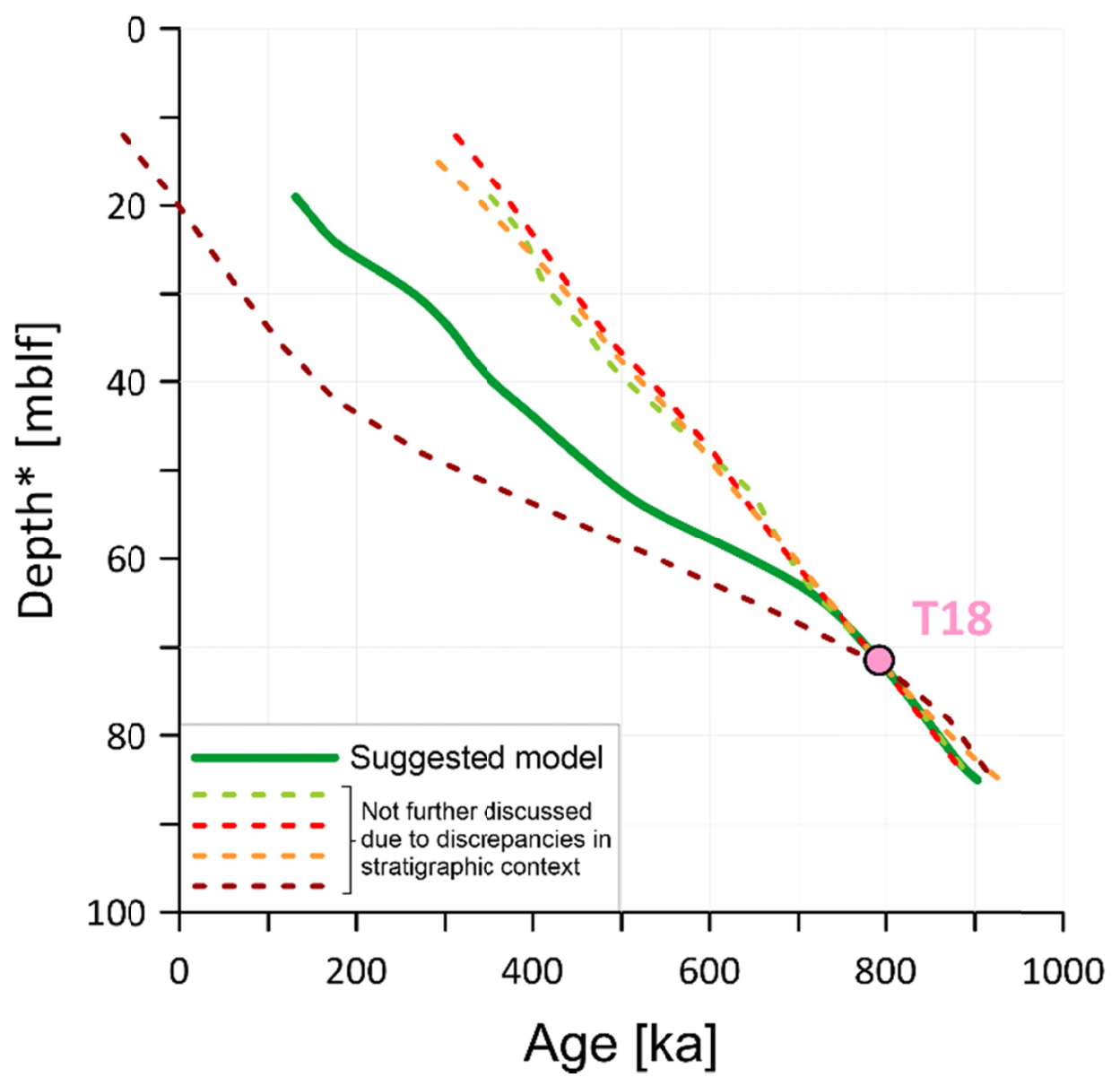

Supplementary Figure S4. Age-depth models from Lake Towuti Unit 1. This figure (from Ulfers et al., 2021) displays the age-depth models for the lacustrine sequence (i.e. Unit 1). The upper part was constrained by $20 \mathrm{AMS}{ }^{14} \mathrm{C}$ ages measured on terrestrial macroremains (Russell et al., 2014). All models are tied to the dated tephra T18 (pink dot) from Russell et al. (2020) at 72.95 mblf. 


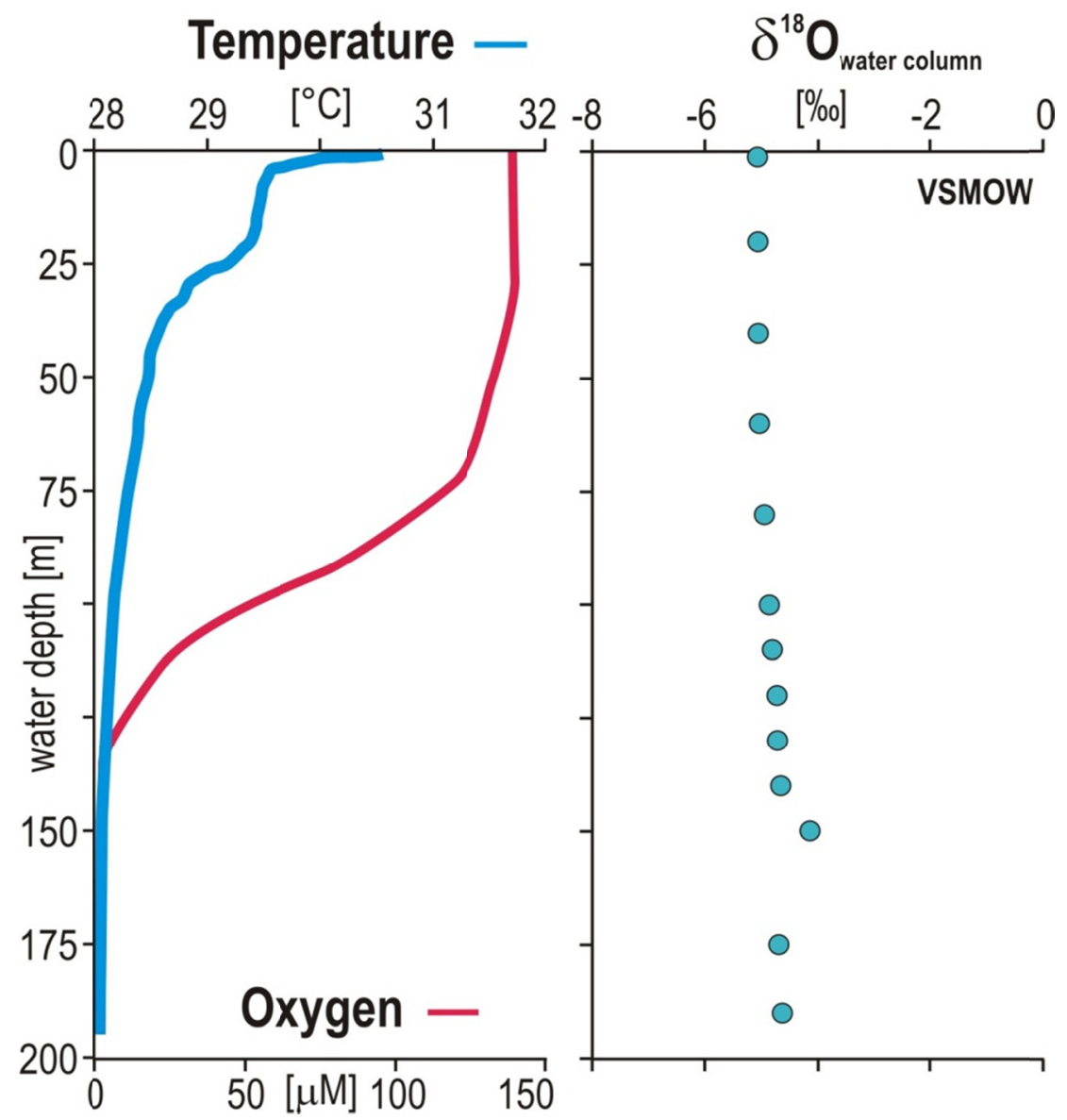

Supplementary Figure S5. Temperatures, oxygen concentrations and isotopes in the water column. (Left) Down cast of temperatures $\left[{ }^{\circ} \mathrm{C}\right]$ and oxygen concentrations $[\mu \mathrm{M}]$ measured in the water column (from Vuillemin et al., 2016). (Right) $\delta^{18} \mathrm{O}$ values [\%] relative to VSMOW for water column samples, which remain fairly constant throughout the water column despite a temperature decrease of $2.5^{\circ} \mathrm{C}$ (see Fig. 4B). 

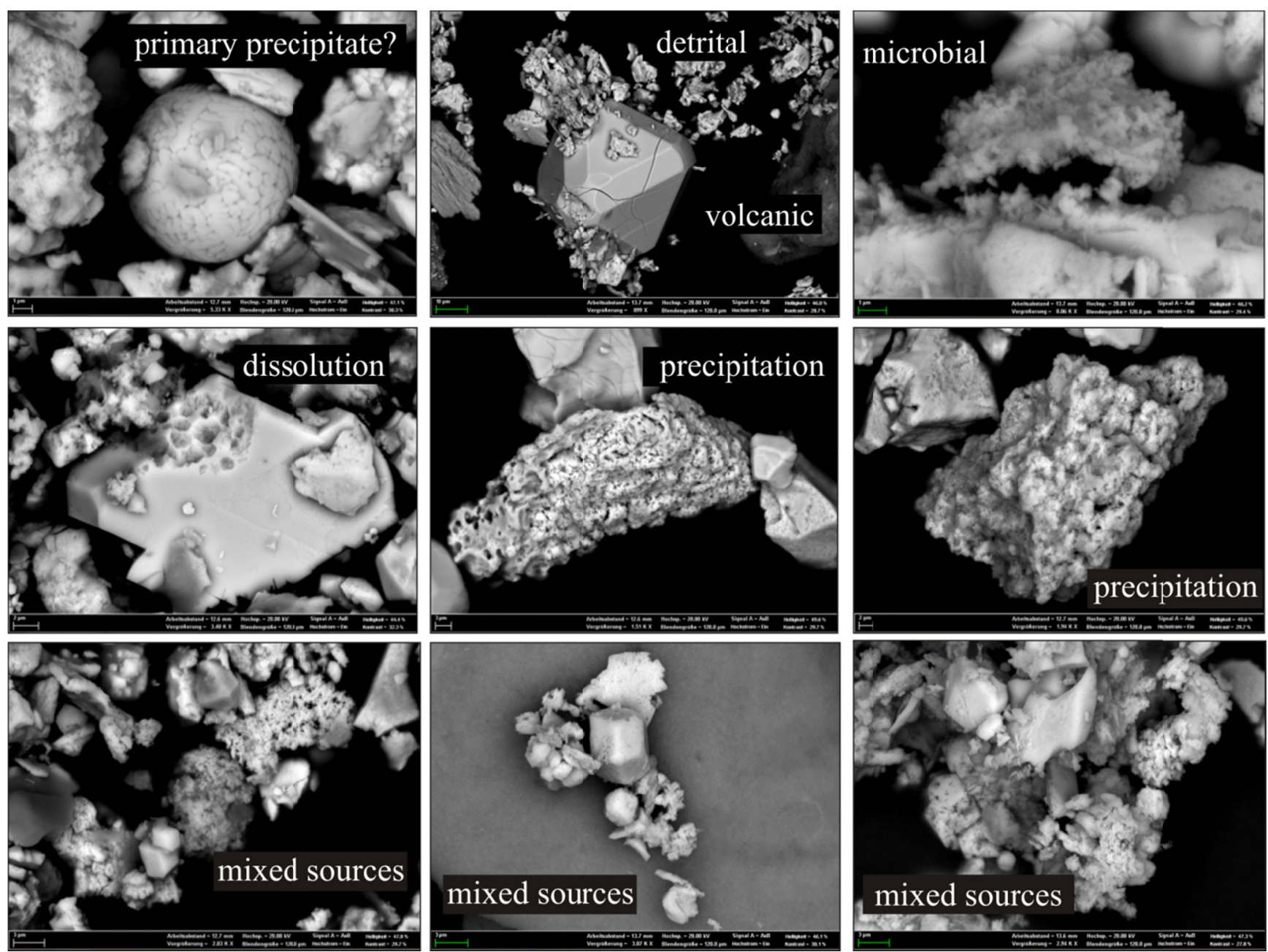

Supplementary Figure S6. SEM back-scatter images of magnetite extracts illustrating their multiple sources. The upper left picture (sediment sample: $0.7 \mathrm{~m}$ depth) shows a magnetite framboid which could be a primary precipitate from the water column. Magnetite crystals are often found as a mixture of aggregated phases (e.g. detrital, volcanic, microbially precipitated), making hard to discriminate those of microbial origin. Nevertheless, features of reductive dissolution and (re)precipitation are commonly observed (modified from Vuillemin et al., 2019). 


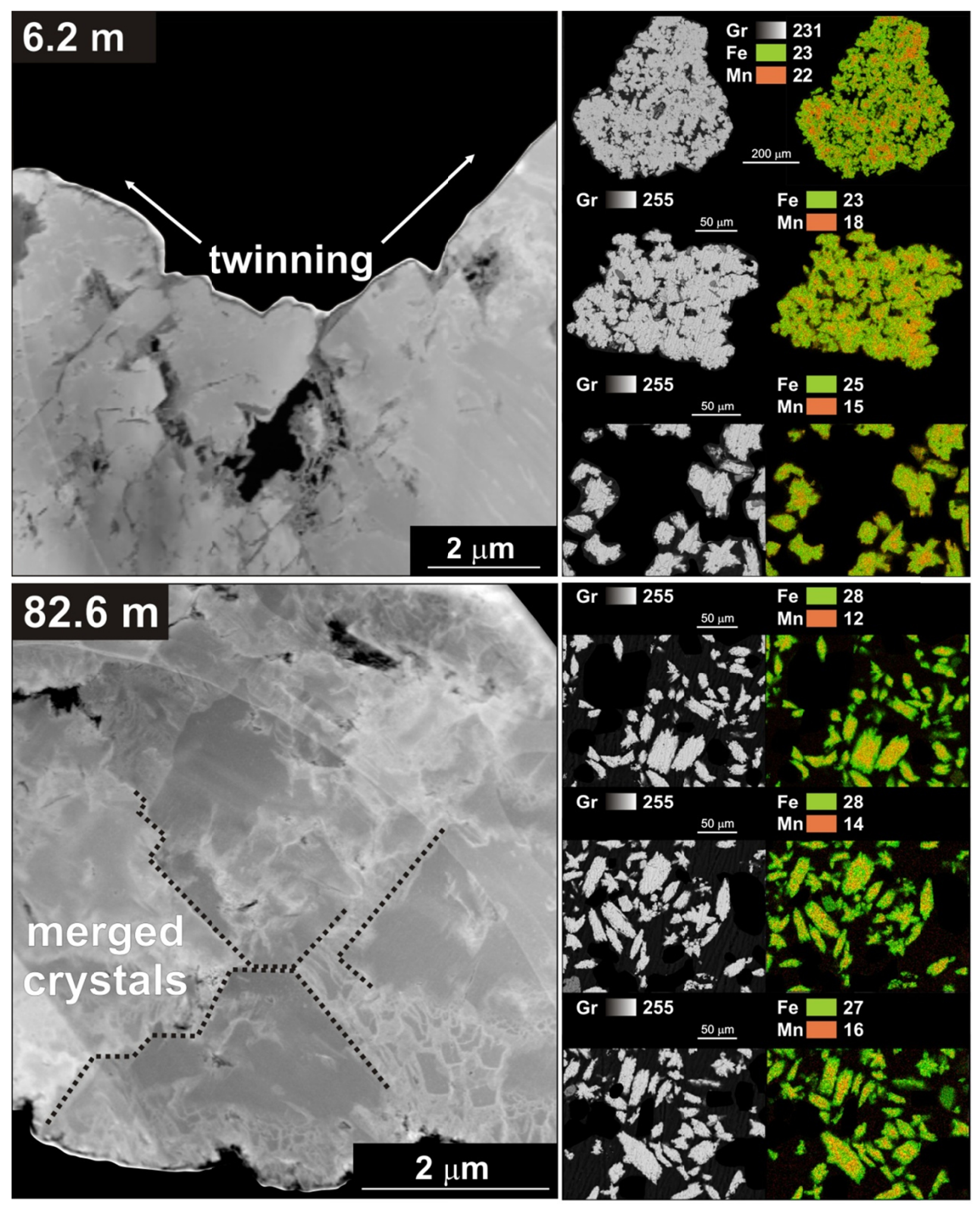

Supplementary Figure S7. Transmission and scanning electron microscopy imaging of siderites with elemental mapping of nuclei and rims. (Left) Scanning TEM images of siderite crystals from 6.2 and 82.6 mblf showing crystal development through twinning and coalescence into mosaic aggregates. (Right) SEM back-scatter electron images with EDS elemental mapping of thin sections prepared with siderite separates from 6.2 and $82.6 \mathrm{~m}$ sediment depth. Stacked intensity images for $\mathrm{Fe}+\mathrm{Mn}$ indicate that $\mathrm{Fe}$ substitution by Mn occurs preferentially in the center of siderite crystals and thereby evidence the presence of nuclei within crystal aggregates (modified from Vuillemin et al., 2019). 

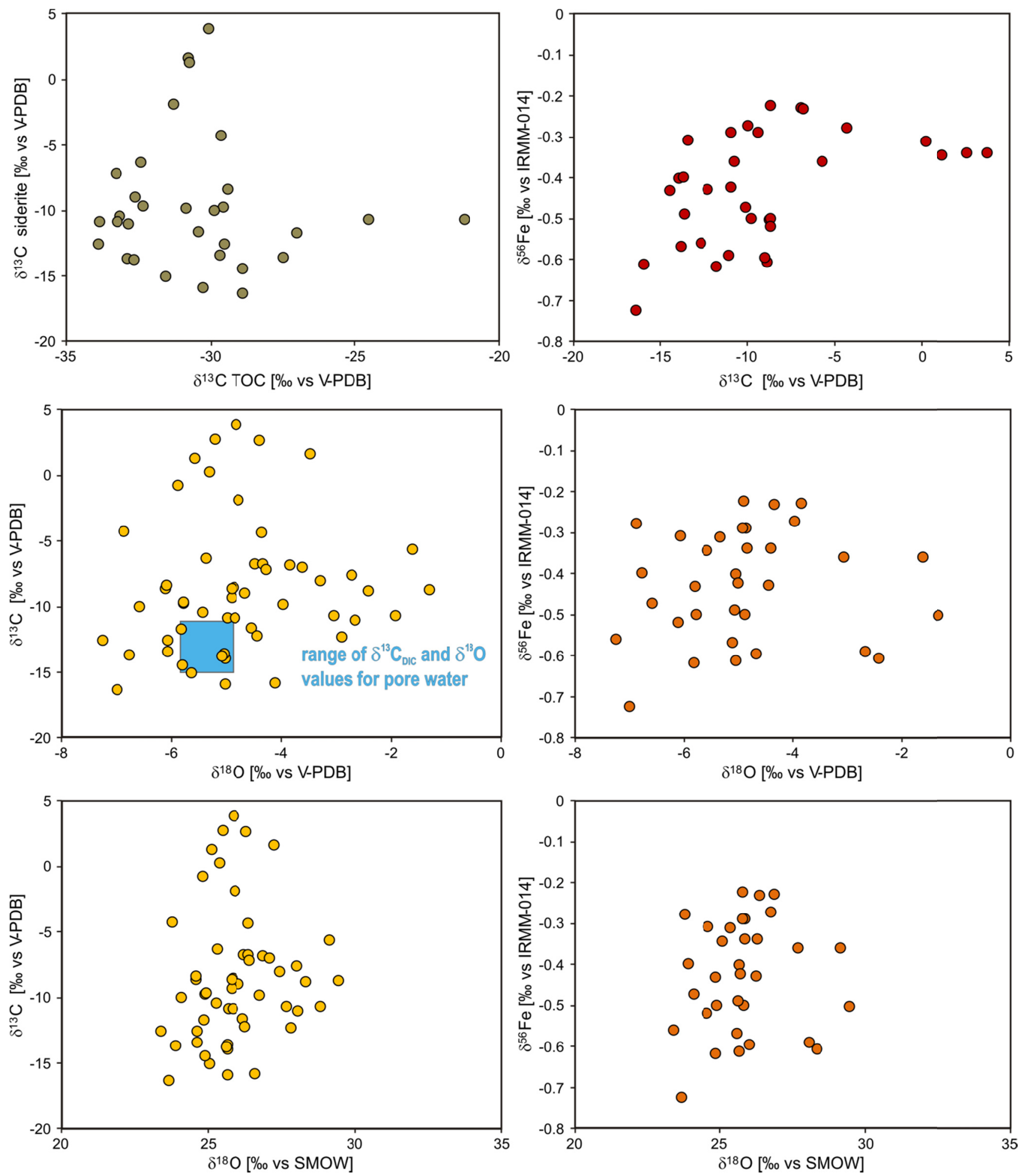

Supplementary Figure S8. Scatter plots of siderite isotope compositions. (Top) Carbon isotope composition $\left(\delta^{13} \mathrm{C}\right.$ in\%o relative to V-PDB) of TOC versus siderite (left); carbon isotope composition $\left(\delta^{13} \mathrm{C}\right.$ in\% relative to V-PDB) versus iron isotope composition $\left(\delta^{56} \mathrm{Fe}\right.$ in\% relative to IRMM-014) measured on siderites. (Middle) Oxygen isotope composition [\%] relative to V-PDB versus carbon (left) isotope composition [\%] relative to V-PDB, and (right) Fe isotope composition [\%] relative to IRMM-014 measured on siderites. (Bottom) Same scatter plots with $\delta^{18} \mathrm{O}$ values [\%] relative to VSMOW. 


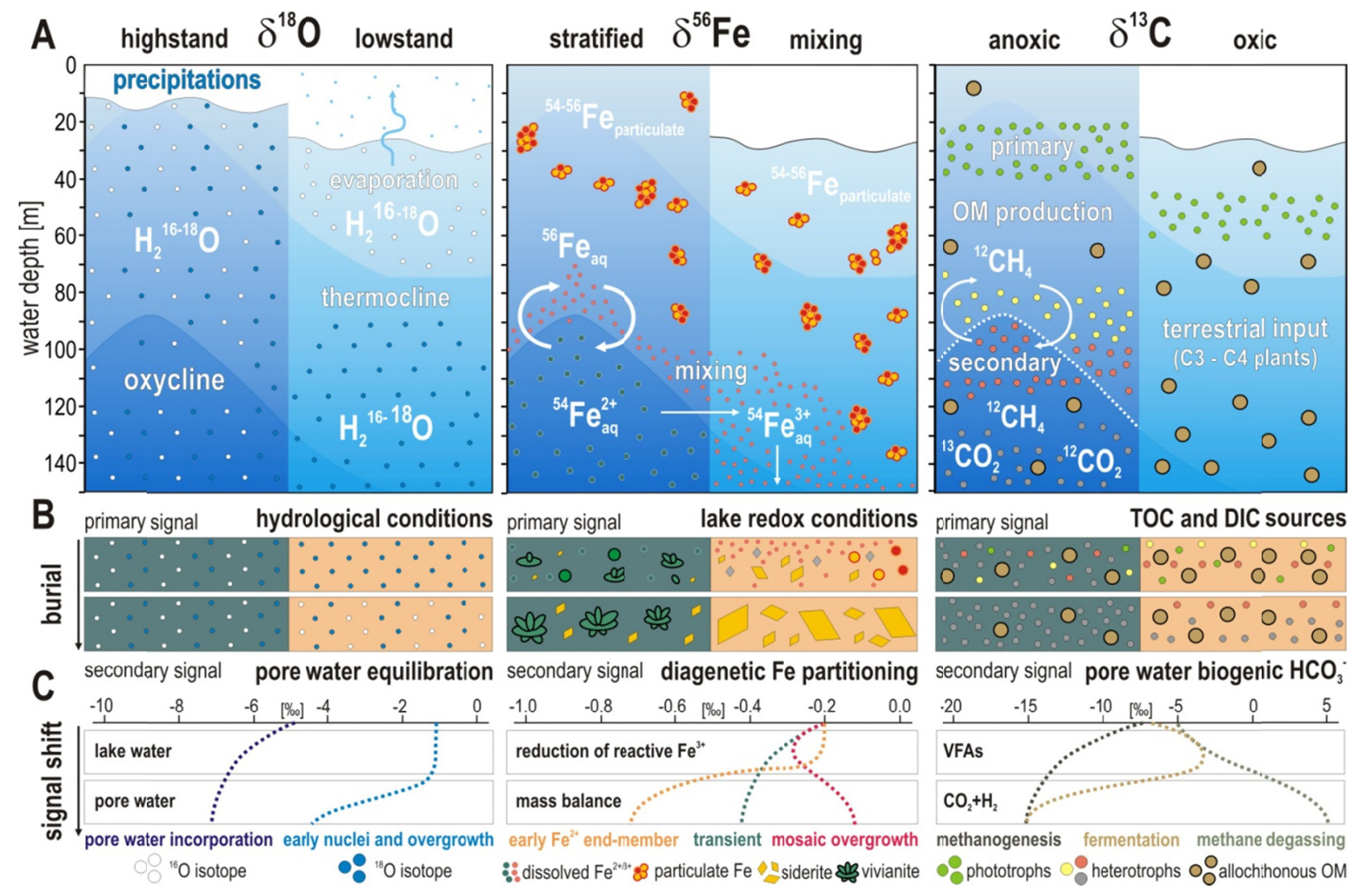

Supplementary Figure S9. Syn-depositional and post-depositional processes setting the $\delta^{18} \mathrm{O}, \delta^{56} \mathrm{Fe}$ and $\delta^{13} \mathbf{C}$ signatures in siderites. (A) Lacustrine conditions, from left to right: ${ }^{18} \mathrm{O}$ composition related to lake level highstand (left) and lowstand (right); sources of detrital and authigenic ferric phases under stratified (left), mixing (center) and oxic conditions in the water column; processes of organic matter production and remineralization in the water column under stratified (left) and mixing (right) conditions. (B) Evolution of sediment composition during shallow (primary signal) to deep (secondary signal) burial. From left to right: Isotopic equilibration from bottom waters, initially reflecting hydrological conditions, to pore water composition; dissolution of Fe precipitates reflecting the lake redox conditions and partitioning of dissolved $\mathrm{Fe}^{2+}$ into diagenetic phases, such as vivianite, and siderite; remineralization of organic sources to methanogenesis through successive anaerobic processes, leading to biogenic production of DIC but little degradation of terrestrial organic sources. (C) General trends in isotope signals expected from the incorporation of pore water $\mathrm{H}_{2} \mathrm{O}$, dissolved $\mathrm{Fe}^{2+}$ and biogenic DIC in siderites in shallow (upper case) and deep sediment (lower case). From left to right: Overgrowth on initial siderite nuclei; reductive dissolution followed by precipitation of Fe phases; and rates of OM remineralization. Continuous mineral precipitation from saturated pore water is expected to lead to a mass balance effect over time. 
Supplementary Table S1. Oxygen isotope fractionation factors between different phases and siderite.

\begin{tabular}{|c|c|c|c|}
\hline Reference & Phases & Temperature & Acid fractionation factor $(\alpha)$ \\
\hline $\begin{array}{l}\text { Rosenbaum \& Sheppard, } 1986 \\
\text { Equation used: } \\
10^{3} \ln \alpha=6.84 \times 10^{5}\left(1 / \mathrm{T}^{2}\right)+3.85\end{array}$ & $\mathrm{CO}_{2}$ - siderite & $\begin{array}{r}25^{\circ} \mathrm{C} \\
50^{\circ} \mathrm{C} \\
\mathbf{7 0}^{\circ} \mathbf{C} \\
100^{\circ} \mathrm{C} \\
150^{\circ} \mathrm{C}\end{array}$ & $\begin{array}{l}1.01163 \\
\text { not measured } \\
\mathbf{1 . 0 0 9 7 0 6} \text { (equation based) } \\
1.00881 \\
1.00771\end{array}$ \\
\hline Fernandez et al., 2016 & $\mathrm{CO}_{2}$ - siderite & $\begin{array}{r}\text { sealed vessel } \\
\mathbf{7 0}^{\circ} \mathbf{C} \\
\end{array}$ & $1.01014 \pm 0.0002$ \\
\hline $\begin{array}{l}\text { Swart et al., } 1991 \\
\text { Equation used: } \\
\alpha=560 \times\left(1 / \mathrm{T}^{2}\right)+1.003943\end{array}$ & $\begin{array}{l}\mathrm{CO}_{2} \text { - calcite } \\
\text { (phosphoric acid) }\end{array}$ & $\begin{array}{r}\text { sealed vessel } \\
90.0^{\circ} \mathrm{C} \\
75.0^{\circ} \mathrm{C} \\
50.0^{\circ} \mathrm{C} \\
35.0^{\circ} \mathrm{C} \\
25.0^{\circ} \mathrm{C} \\
\text { sealed vessel } \\
89.9^{\circ} \mathrm{C} \\
81.0^{\circ} \mathrm{C} \\
70.6^{\circ} \mathrm{C} \\
59.7^{\circ} \mathrm{C} \\
50.9^{\circ} \mathrm{C} \\
25.0^{\circ} \mathrm{C} \\
\end{array}$ & $\begin{array}{l}1.00821 \\
1.00853 \\
1.00924 \\
1.00982 \\
1.01025 \\
\\
1.00827 \\
1.00854 \\
1.00929 \\
1.00961 \\
1.01000 \\
1.01025\end{array}$ \\
\hline Carothers et al., 1988 & $\begin{array}{l}\mathrm{CO}_{2}-\text { siderite } \\
\text { (phosphoric acid) }\end{array}$ & $\begin{array}{r}\text { natural } 25^{\circ} \mathrm{C} \\
\text { synthetic } 25^{\circ} \mathrm{C} \\
\text { natural } 50^{\circ} \mathrm{C} \\
\text { synthetic } 50^{\circ} \mathrm{C}\end{array}$ & $\begin{array}{l}1.01165 \\
1.01175 \\
1.01079 \\
1.01075\end{array}$ \\
\hline $\begin{array}{l}\text { Pore water to siderite } \\
\text { Factor used: } 1.03033 \\
\mathrm{~T}^{\circ} \text { range in Towuti: } 28 \text { to } 33^{\circ} \mathrm{C}\end{array}$ & $\mathrm{H}_{2} \mathrm{O}$ - siderite & $\begin{array}{r}33^{\circ} \mathrm{C} \\
56^{\circ} \mathrm{C} \\
103^{\circ} \mathrm{C} \\
150^{\circ} \mathrm{C} \\
197^{\circ} \mathrm{C}\end{array}$ & $\begin{array}{l}\mathbf{1 . 0 3 0 3 3} \\
1.02640 \\
1.01893 \\
1.01322 \\
1.01067\end{array}$ \\
\hline & $\mathrm{H}_{2} \mathrm{O}$ - calcite & $\begin{array}{l}102^{\circ} \mathrm{C} \\
102^{\circ} \mathrm{C}\end{array}$ & $\begin{array}{l}1.01750 \\
1.01740\end{array}$ \\
\hline $\begin{array}{l}\text { Van Dijk et al., } 2018 \\
\text { Equation used: } \\
10^{3} \ln \alpha=19.67 \pm 0.42 \times\left(10^{3} / \mathrm{T}^{2}\right)-36.27 \pm 1.34 \\
\text { Acid fractionation used: } \\
\left.\text { open vessel at } 100^{\circ} \mathrm{C} \text { (Fernandez et al., } 2016\right)\end{array}$ & $\mathrm{H}_{2} \mathrm{O}$ - siderite & $\begin{array}{c}8.5^{\circ} \mathrm{C} \\
8.5^{\circ} \mathrm{C} \\
8.5^{\circ} \mathrm{C} \\
18^{\circ} \mathrm{C} \\
18^{\circ} \mathrm{C} \\
18^{\circ} \mathrm{C} \\
25^{\circ} \mathrm{C} \\
\mathbf{2 8}^{\circ} \mathrm{C} \\
2^{\circ} \mathrm{C} \\
37^{\circ} \mathrm{C} \\
42^{\circ} \mathrm{C} \\
47^{\circ} \mathrm{C} \\
52^{\circ} \mathrm{C} \\
57^{\circ} \mathrm{C} \\
62^{\circ} \mathrm{C}\end{array}$ & $\begin{array}{l}1.0343 \\
1.0320 \\
1.0342 \\
1.0319 \\
1.0312 \\
1.0312 \\
1.0301 \\
\mathbf{1 . 0 2 9 7} \\
\mathbf{1 . 0 2 9 4} \\
1.0279 \\
1.0265 \\
1.0254 \\
1.0243 \\
1.0235 \\
1.0227\end{array}$ \\
\hline Mortimer \& Coleman, 1997 & $\mathrm{H}_{2} \mathrm{O}$ - siderite & $\begin{array}{l}\text { Fe pure } 30^{\circ} \mathrm{C} \\
\text { Fe pure } 30^{\circ} \mathrm{C} \\
\text { Fe pure } 30^{\circ} \mathrm{C} \\
\text { Fe pure } 30^{\circ} \mathrm{C} \\
\text { Fe pure } 30^{\circ} \mathrm{C} \\
\text { Fe pure } 30^{\circ} \mathrm{C} \\
\end{array}$ & $\begin{array}{l}1.0203 \\
1.0224 \\
1.0257 \\
1.0245 \\
1.0251 \\
1.0275\end{array}$ \\
\hline
\end{tabular}




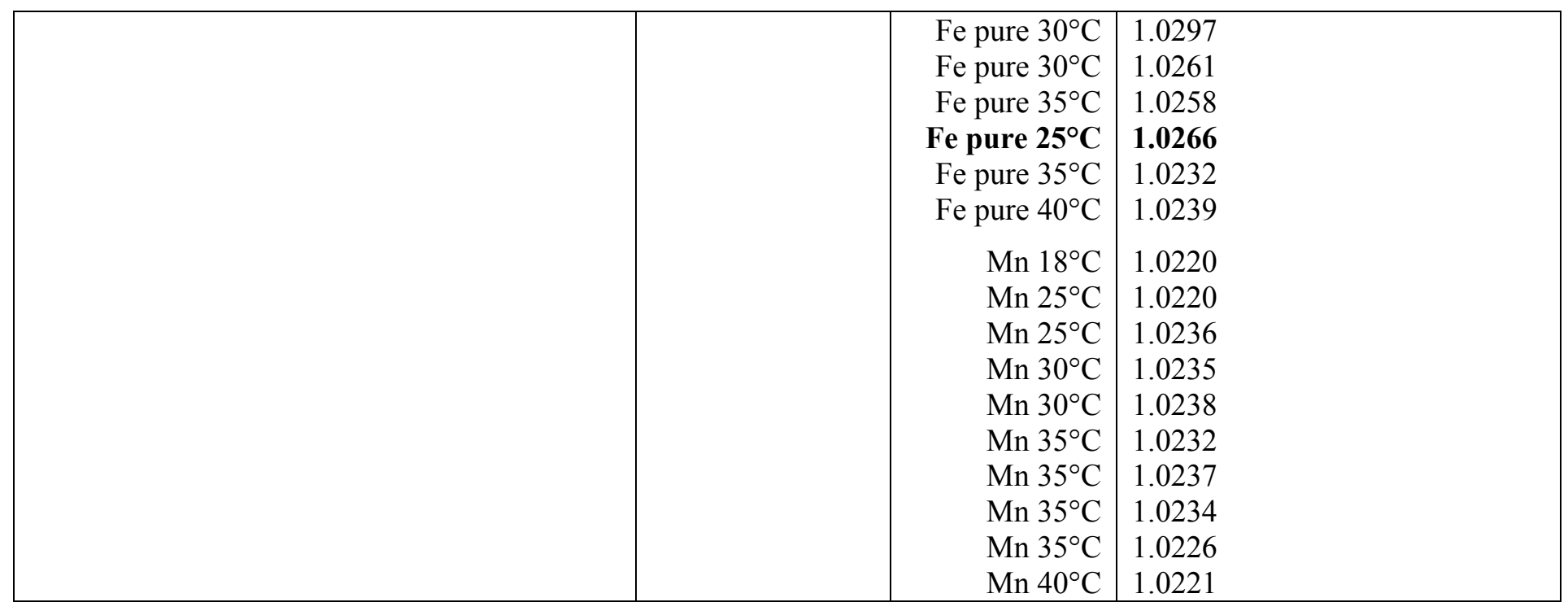


Supplementary Table S2. Siderite oxygen isotope values calculated with different acid fractionation factors based on equations of Rosenbaum \& Sheppard (1986), and Fernandez et al. (2016).

\begin{tabular}{|c|c|c|c|c|}
\hline $\begin{array}{l}\text { Sample ID } \\
\text { Top to bottom }\end{array}$ & $\begin{array}{c}\delta^{18} \mathbf{O} \text { uncorrected } \\
\text { calcite standard calibration } \\
\text { (NBS } 18, \text { NBS } 19, \text { Pfeil) }\end{array}$ & $\begin{array}{c}\delta^{\mathbf{1 8}} \mathbf{O} \text { siderite calibrated } \\
\text { acid fractionation factor } \\
\text { (Rosenbaum \& Sheppard, 1986) }\end{array}$ & $\begin{array}{l}\boldsymbol{\delta}^{18} \mathbf{O} \text { siderite calibrated } \\
\text { acid fractionation factor } \\
\text { (Fernandez et al., 2016) }\end{array}$ & $\begin{array}{c}\text { Difference } \\
{[\%]}\end{array}$ \\
\hline $4 \mathrm{H} 2$ & -1.7 & -2.6 & -3.0 & 0.3755 \\
\hline $4 \mathrm{H} 4$ & -1.9 & -2.9 & -3.2 & 0.3751 \\
\hline $5 \mathrm{H} 6$ & -6.3 & -7.2 & -7.6 & 0.3693 \\
\hline $6 \mathrm{H} 2$ & -4.8 & -5.8 & -6.2 & 0.3712 \\
\hline $7 \mathrm{H} 6$ & -6.0 & -7.0 & -7.3 & 0.3696 \\
\hline $9 \mathrm{H} 2 \mathrm{~A}$ & -4.0 & -5.0 & -5.4 & 0.3723 \\
\hline $9 \mathrm{H} 2 \mathrm{~B}$ & -4.1 & -5.0 & -5.4 & 0.3722 \\
\hline $9 \mathrm{H} 3$ & -3.5 & -4.4 & -4.8 & 0.3731 \\
\hline $16 \mathrm{H} 2$ & -4.8 & -5.8 & -6.1 & 0.3712 \\
\hline $17 \mathrm{H} 1$ & -3.7 & -4.6 & -5.0 & 0.3728 \\
\hline $17 \mathrm{H} 2$ & -4.1 & -5.1 & -5.4 & 0.3722 \\
\hline $18 \mathrm{H} 1$ & -4.4 & -5.4 & -5.8 & 0.3717 \\
\hline $22 \mathrm{H} 3$ & -4.0 & -5.0 & -5.3 & 0.3723 \\
\hline $24 \mathrm{H} 2$ & -3.9 & -4.8 & -5.2 & 0.3725 \\
\hline $25 \mathrm{H} 1$ & -3.9 & -4.9 & -5.3 & 0.3724 \\
\hline $28 \mathrm{H} 3$ & -3.0 & -3.9 & -4.3 & 0.3737 \\
\hline 29H3 & -3.9 & -4.9 & -5.2 & 0.3724 \\
\hline $30 \mathrm{H} 3$ & -2.3 & -3.3 & -3.7 & 0.3746 \\
\hline $31 \mathrm{H} 1$ & -3.3 & -4.3 & -4.7 & 0.3732 \\
\hline $33 \mathrm{H} 1$ & -3.3 & -4.3 & -4.6 & 0.3733 \\
\hline $33 \mathrm{H} 2$ & -4.4 & -5.4 & -5.7 & 0.3718 \\
\hline $35 \mathrm{H} 2$ & -3.8 & -4.8 & -5.1 & 0.3726 \\
\hline $35 \mathrm{H} 3$ & -4.3 & -5.3 & -5.7 & 0.3719 \\
\hline $36 \mathrm{H} 1$ & -2.5 & -3.5 & -3.8 & 0.3744 \\
\hline $36 \mathrm{H} 3$ & -3.4 & -4.4 & -4.7 & 0.3731 \\
\hline $37 \mathrm{H} 2$ & -3.8 & -4.8 & -5.2 & 0.3725 \\
\hline $39 \mathrm{H} 1$ & -4.2 & -5.2 & -5.6 & 0.3720 \\
\hline $40 \mathrm{H} 1$ & -4.6 & -5.6 & -5.9 & 0.3715 \\
\hline 41H3 & -5.1 & -6.1 & -6.4 & 0.3708 \\
\hline $42 \mathrm{H} 1$ & -5.1 & -6.0 & -6.4 & 0.3709 \\
\hline
\end{tabular}




\section{Supplementary Table S3. Results of iron isotope analyses on siderite samples and reference materials}

for data quality control. Measurement accuracy and precision was assessed by repeated analyses of pure $\mathrm{Fe}$ standard solution (HanFe) in each analytical session. This standard gave ${ }^{56} \mathrm{Fe}$ of $0.31 \pm 0.02(2 \mathrm{~s}, \mathrm{n}=10)$, identical to results obtained in an inter-laboratory comparison. The procedure was also tested by processing the reference materials COQ-1 and BHVO-2 repeatedly through the same chromatographic separation protocol as the samples, with and without $\mathrm{HCl}$ or acetic acid treatment. This method yielded ${ }^{56} \mathrm{Fe}$ values for COQ-1 of $-0.04 \pm 0.04(2 \sigma, n=4),-0.02 \pm 0.04(2 \sigma, n=4),-0.05 \pm 0.04(2 \sigma, n=2)$, and for BHVO-2 $-0.12 \pm$ $0.01(2 \sigma, \mathrm{n}=2)$, which are in agreement with published results. In addition, a pure siderite mineral powder was used to test the acetic acid leaching method. The ${ }^{56} \mathrm{Fe}$ results of siderite leached with $10 \%$ acetic acid ($0.37 \%$ ) are identical to the reference value obtained by complete dissolution of the same siderite powder in $6 \mathrm{M} \mathrm{HCl}(-0.35 \%)$.

\begin{tabular}{|c|c|c|c|c|c|c|c|}
\hline sample & dissolution procedure & $\delta^{56} \mathbf{F e}$ & depth (mblf) & sample & dissolution procedure & $\delta^{56} \mathbf{F e}$ & depth (mblf) \\
\hline siderite & & & & $17 \mathrm{H1}$ & $10 \%$ acetic acid, $24 \mathrm{~h}$ & -0.59 & 41.1 \\
\hline $1 \mathrm{H} 1$ & $10 \%$ acetic acid, $24 \mathrm{~h}$ & -0.23 & 0.2 & $18 \mathrm{H} 1$ & $10 \%$ acetic acid, $24 \mathrm{~h}$ & -0.56 & 43.0 \\
\hline $3 \mathrm{H} 3$ & $10 \%$ acetic acid, $24 \mathrm{~h}$ & -0.36 & 6.2 & $22 \mathrm{H} 3$ & $10 \%$ acetic acid, $24 \mathrm{~h}$ & -0.62 & 49.4 \\
\hline $5 \mathrm{H} 3$ & $10 \%$ acetic acid, $24 \mathrm{~h}$ & -0.50 & 12.4 & $24 \mathrm{H} 2$ & $10 \%$ acetic acid, $24 \mathrm{~h}$ & -0.73 & 52.8 \\
\hline $15 \mathrm{~A} 3$ & $10 \%$ acetic acid, $24 \mathrm{~h}$ & -0.40 & 36.7 & $25 \mathrm{H} 1$ & $10 \%$ acetic acid, $24 \mathrm{~h}$ & -0.61 & 54.2 \\
\hline $29 \mathrm{H} 3$ & $10 \%$ acetic acid, $24 \mathrm{~h}$ & -0.43 & 36.7 & $28 \mathrm{H} 3$ & $10 \%$ acetic acid, $24 \mathrm{~h}$ & -0.49 & 60.3 \\
\hline $34 \mathrm{H} 3$ & $10 \%$ acetic acid, $24 \mathrm{~h}$ & -0.29 & 76.7 & $30 \mathrm{H} 3$ & $10 \%$ acetic acid, $24 \mathrm{~h}$ & -0.60 & 65.7 \\
\hline $36 \mathrm{H} 3$ & $10 \%$ acetic acid, $24 \mathrm{~h}$ & -0.25 & 82.6 & $31 \mathrm{H} 1$ & $10 \%$ acetic acid, $24 \mathrm{~h}$ & -0.57 & 67.1 \\
\hline $36 \mathrm{H} 3$ & $10 \%$ acetic acid, $24 \mathrm{~h}$ replicate ${ }^{\mathrm{a}}$ & -0.22 & 82.6 & $33 \mathrm{H} 2$ & $10 \%$ acetic acid, $24 \mathrm{~h}$ replicate & -0.42 & 71.4 \\
\hline $37 \mathrm{H} 3$ & $10 \%$ acetic acid, $24 \mathrm{~h}$ & -0.28 & 85.6 & $35 \mathrm{H} 3$ & $10 \%$ acetic acid, $24 \mathrm{~h}$ & -0.27 & 78.8 \\
\hline $38 \mathrm{H} 3$ & $10 \%$ acetic acid, $24 \mathrm{~h}$ & -0.31 & 88.6 & $36 \mathrm{H1}$ & $10 \%$ acetic acid, $24 \mathrm{~h}$ & -0.23 & 80.8 \\
\hline $39 \mathrm{H} 3$ & $10 \%$ acetic acid, $24 \mathrm{~h}$ & -0.34 & 91.6 & & & & \\
\hline $41 \mathrm{H} 3$ & $10 \%$ acetic acid, $24 \mathrm{~h}$ & -0.34 & 96.4 & & & & \\
\hline $48 \mathrm{H} 3$ & $10 \%$ acetic acid, $24 \mathrm{~h}$ & -0.28 & 113.6 & vivianite & & & \\
\hline $4 \mathrm{H} 2$ & $10 \%$ acetic acid, $24 \mathrm{~h}$ & -0.50 & 7.1 & $9 \mathrm{H} 3$ & $2 \mathrm{M}$ nitric acid, $24 \mathrm{~h}$ & -0.44 & 23.4 \\
\hline $4 \mathrm{H} 4$ & $10 \%$ acetic acid, $24 \mathrm{~h}$ & -0.61 & 8.8 & $9 \mathrm{H} 3$ & $2 \mathrm{M}$ nitric acid, $24 \mathrm{~h}$ & -0.52 & 23.4 \\
\hline $7 \mathrm{H} 6$ & $10 \%$ acetic acid, $24 \mathrm{~h}$ & -0.31 & 18.0 & $15 \mathrm{~A} 3$ & $2 \mathrm{M}$ nitric acid, $24 \mathrm{~h}$ & -0.61 & 36.7 \\
\hline $9 \mathrm{H} 2 \mathrm{~A}$ & $10 \%$ acetic acid, $24 \mathrm{~h}$ & -0.52 & 21.2 & $21 \mathrm{~A} 1$ & $2 \mathrm{M}$ nitric acid, $24 \mathrm{~h}$ & -0.46 & 46.8 \\
\hline $9 \mathrm{H} 3$ & $10 \%$ acetic acid, $24 \mathrm{~h}$ & -0.47 & 21.8 & $21 \mathrm{Al}$ & 2M nitric acid, $24 \mathrm{~h}$ & -0.39 & 46.8 \\
\hline
\end{tabular}

\begin{tabular}{|c|c|c|c|c|c|c|c|}
\hline reference & & $\delta^{56} \mathrm{Fe}$ & $2 \sigma$ deviation & literature & & $\delta^{56} \mathrm{Fe}$ & \\
\hline HanFe & pure Fe solution - not processed & 0.31 & $\pm 0.02(\mathrm{n}=10)$ & $\mathrm{HanFe}$ & pure Fe solution - not processed & 0.29 & Moeller et al. (2014) \\
\hline BHVO-2 & $10 \%$ acet. $\mathrm{acid} / 24 \mathrm{~h}$, then $\mathrm{HF} / \mathrm{HNO}_{3}$ & -0.12 & $\pm 0.01(\mathrm{n}=2)$ & COQ-1 & total digestion & -0.12 & Craddock and Dauphas (2011) \\
\hline COQ-1 & $10 \%$ acet. $\mathrm{acid} / 24 \mathrm{~h}$, then $\mathrm{HF} / \mathrm{HNO}_{3}$ & -0.05 & $\pm 0.04(\mathrm{n}=2)$ & COQ-1 & total digestion & 0.00 & Dideriksen et al. (2006) \\
\hline COQ-1 & $6 \mathrm{M} \mathrm{HCl} / 24 \mathrm{~h}$, then $\mathrm{HF} / \mathrm{HNO}_{3}$ & -0.02 & $\pm 0.04(n=4)$ & COQ-1 & total digestion & 0.07 & Dideriksen et al. (2006) \\
\hline COQ-1 & $\mathrm{HCl} / \mathrm{HF} / \mathrm{HNO}_{3}$ total digestion & -0.04 & $\pm 0.04(n=4)$ & COQ-1 & total digestion & -0.07 & He et al. (2015) \\
\hline & & & & BHVO-2 & total digestion & 0.11 & Craddock and Dauphas (2011) \\
\hline
\end{tabular}

The uncertainty in the Fe isotope data is $0.05 \%\left(2 \sigma, \delta^{56} \mathrm{Fe}\right)$.

${ }^{a}$ Full procedure replicate incl. sample dissolution of a different crystal (vivianite), Fe column chemistry purification and measurement by MC-ICP-MS. 
Supplementary Table S4. Results of EDS analyses on magnetic extracts and corresponding SEM images. Potentially authigenic magnetites are signified in red values.

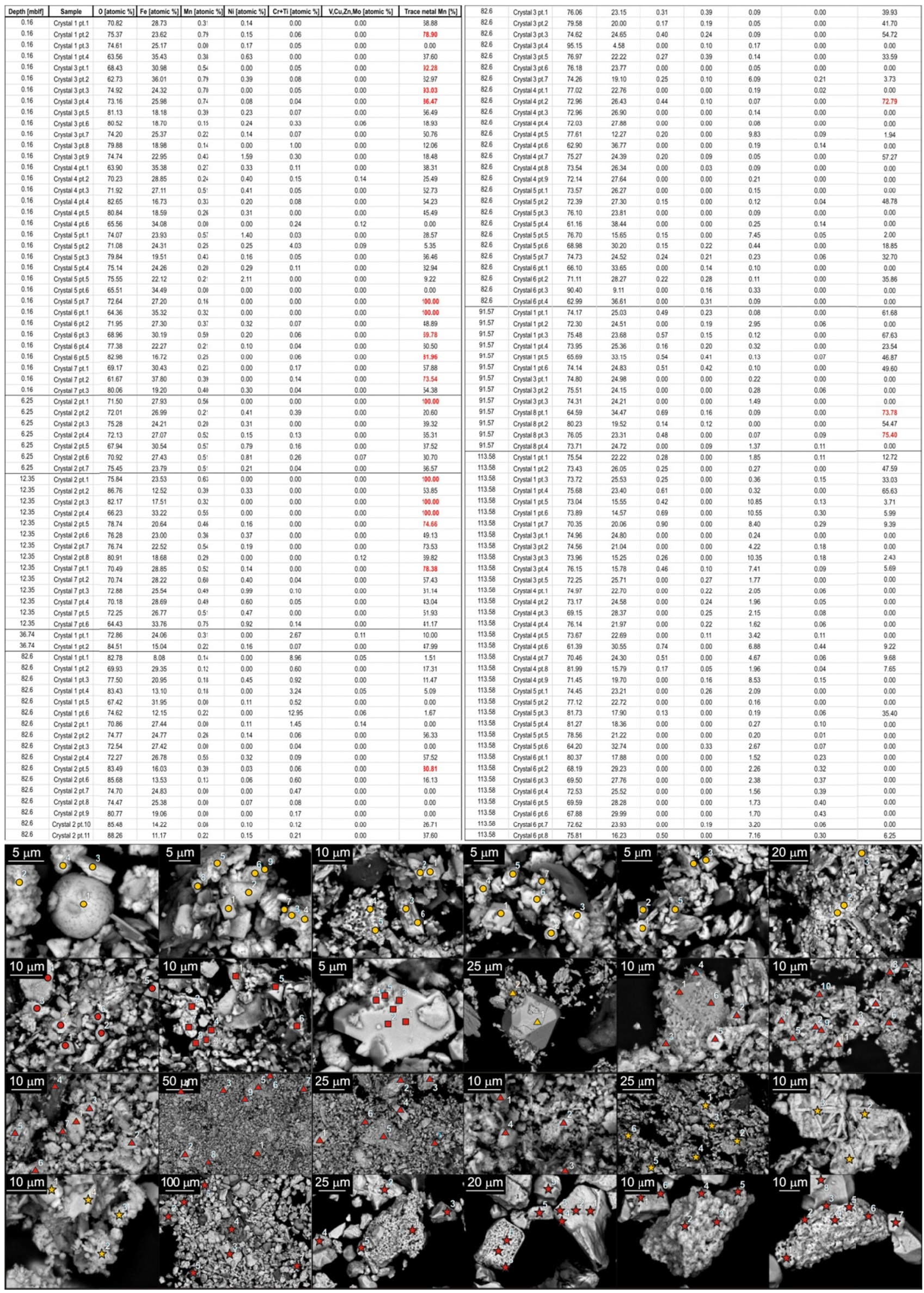


Supplementary Table S5. Results of EDS analyses on siderite samples and corresponding SEM images.

\begin{tabular}{|c|c|c|c|c|c|c|c|c|c|c|c|c|c|}
\hline Depth [mbif] & Sample & Mg [atomic \%] & Ca [atomic \%] & Mn [atomic \&] & Fe [atomic \%] & $\mathrm{O}$ [atomic \%] & Depth [mblf] & Sample & |Ng [atomic \%] & Ca [atomic \%] & Mn [atomic \%] & $\mid \mathrm{Fe}$ [atomic \%] & 0 [atcmic \%] \\
\hline 0.46 & Crystal 1 & 1.60 & 0.43 & 0.59 & 20.53 & 43.97 & 36.74 & Crystal 6 & 0.29 & 0.17 & 0.88 & 8.84 & 70.98 \\
\hline 0.6 & Crystal 1 & 1.75 & 0.41 & 0.84 & 23.55 & 40.98 & 36.74 & Crystal 6 & 0.30 & 0.17 & 1.09 & 15.28 & 58.51 \\
\hline 0.6 & Crystal 1 & 5.81 & 0.51 & 0.45 & 17.12 & 46.90 & 36.74 & Crystal 6 & 0.33 & 0.09 & 0.96 & 13.44 & 62.79 \\
\hline 0.6 & Crystal 1 & 0.44 & 0.55 & 0.86 & 22.54 & 41.68 & 36.74 & Cystal 6 & 0.38 & 0.08 & 0.60 & 8.79 & 74.85 \\
\hline 0.6 & Crystal 2 & 1.28 & 0.23 & 0.27 & 11.73 & 64.70 & 36.74 & Crystal 6 & 0.00 & 0.22 & 1.23 & 12.35 & 63.74 \\
\hline 0.6 & Crystal 2 & 0.35 & 0.20 & 0.43 & 4.31 & 84.23 & 36.74 & Crystal 6 & 0.00 & 0.22 & 1.29 & 12.38 & 6.94 \\
\hline 0.6 & Crystal 2 & 4.26 & 0.31 & 0.21 & 8.87 & 70.12 & 36.74 & Crystal 6 & 0.24 & 0.18 & 1.39 & 14.63 & 59.51 \\
\hline 0.6 & Crystal 2 & 1.09 & 0.32 & 0.51 & 15.97 & 57.57 & 36.74 & Crystal 6 & 0.31 & 0.19 & 2.11 & 13.46 & 59.93 \\
\hline 0.6 & Crystal 3 & 0.29 & 0.15 & 3.26 & 7.66 & 67.44 & 82.6 & Crystal 2 & 0.51 & 0.09 & 0.26 & 11.07 & $7: 23$ \\
\hline 0.6 & Crystal 3 & 0.35 & 0.22 & 3.53 & 11.31 & 58.16 & 82.6 & Crystal 2 & 3.17 & 0.00 & 0.00 & 4.52 & 75.98 \\
\hline 0.6 & Crystal 3 & 0.76 & 0.20 & 4.11 & 11.11 & 57.65 & 82.6 & Cystal 2 & 0.53 & 0.12 & 0.39 & 11.69 & 67.45 \\
\hline 0.6 & Crystal 3 & 0.40 & 0.33 & 6.10 & 19.47 & 39.06 & 82.6 & Crystal 3 & 0.35 & 0.12 & 1.00 & 13.86 & 62.06 \\
\hline 0.6 & Crystal 3 & 0.58 & 0.38 & 7.71 & 17.83 & 38.67 & 82.6 & Crystal 3 & 0.49 & 0.14 & 0.52 & 13.03 & 65.06 \\
\hline 0.6 & Crystal 3 & 1.24 & 0.33 & 6.42 & 18.11 & 39.91 & 82.6 & Crystal 3 & 0.55 & 0.17 & 0.99 & 13.55 & 6.69 \\
\hline 0.6 & Crystal 6 & 1.81 & 0.14 & 0.71 & 16.98 & 55.68 & 82.6 & Crystal 3 & 0.53 & 0.15 & 0.54 & 13.75 & $6 \times .48$ \\
\hline 0.6 & Crystal 6 & 2.69 & 0.16 & 0.62 & 13.72 & 60.98 & 82.6 & Crystal 3 & 0.33 & 0.10 & 0.96 & 13.44 & 62.90 \\
\hline 0.6 & Cystal 7 & 1.26 & 0.36 & 1.02 & 13.27 & 60.82 & 82.6 & Crystal 4 & 0.51 & 0.15 & 1.01 & 15.46 & 58.27 \\
\hline 0.6 & Cystal 7 & 1.86 & 0.35 & 0.93 & 14.50 & 58.20 & 82.6 & Crystal 4 & 0.64 & 0.18 & 0.53 & 15.91 & 58.58 \\
\hline 0.6 & Crystal 7 & 1.40 & 0.33 & 0.77 & 11.04 & 65.52 & 82.6 & Crystal 4 & 0.46 & 0.10 & 0.57 & 12.50 & 67.28 \\
\hline 0.6 & Crystal 8 & 0.34 & 0.23 & 3.73 & 12.43 & 56.63 & 82.6 & Crystal 7 & 0.46 & 0.09 & 0.19 & 10.14 & 73.30 \\
\hline 0.6 & Cystal 8 & 0.55 & 0.21 & 3.54 & 12.65 & 55.58 & 82.6 & Crystal 7 & 0.46 & 0.10 & 0.86 & 12.96 & 63.91 \\
\hline 0.6 & Crystal 8 & 1.46 & 0.20 & 3.78 & 9.72 & 59.19 & 82.6 & Crystal 7 & 0.59 & 0.12 & 0.56 & 12.91 & 69.50 \\
\hline 0.6 & Crystal 9 & 0.14 & 0.12 & 1.64 & 18.19 & 51.82 & 82.6 & Crystal 8 & 0.65 & 0.13 & 0.43 & 12.36 & 65.41 \\
\hline 0.6 & Crystal 9 & 0.29 & 0.10 & 1.22 & 16.35 & 55.10 & 82.6 & Crystal 8 & 0.24 & 0.13 & 0.92 & 18.30 & 54.00 \\
\hline 0.6 & Crystal 9 & 0.24 & 0.09 & 1.45 & 14.80 & 57.53 & 82.6 & Crystal 8 & 1.01 & 0.31 & 0.14 & 10.79 & $7: 00$ \\
\hline 0.6 & Crystal 10 & 0.70 & 0.20 & 0.35 & 16.10 & 58.74 & 82.6 & Crystal 8 & 0.70 & 0.17 & 0.38 & 14.50 & 6.57 \\
\hline 0.6 & Cystal 10 & 0.56 & 0.25 & 0.49 & 17.53 & 55.72 & 82.6 & Crystal 12 & 0.33 & 0.13 & 1.20 & 15.02 & 59.99 \\
\hline 0.6 & Crystal 10 & 0.77 & 0.26 & 0.30 & 15.27 & 60.37 & 82.6 & Crystal 12 & 0.43 & 0.13 & 1.02 & 15.23 & 59.40 \\
\hline 0.6 & Crystal 11 & 0.79 & 0.29 & 0.27 & 13.72 & 65.12 & 82.6 & Crystal 12 & 2.14 & 0.19 & 0.28 & 12.24 & 64.03 \\
\hline 0.6 & Crystal 11 & 0.04 & 0.25 & 0.74 & 24.98 & 40.52 & 82.6 & Crystal 12 & 0.48 & 0.13 & 0.60 & 14.09 & 62.98 \\
\hline 0.6 & Crystal 11 & 0.21 & 0.37 & 1.65 & 22.20 & 43.97 & 91.57 & Crystal 2 & 1.36 & 0.45 & 0.36 & 13.64 & 62.18 \\
\hline 0.6 & Crystal 11 & 1.63 & 0.72 & 0.13 & 18.17 & 53.37 & 91.57 & Crystal 2 & 1.14 & 0.35 & 0.58 & 11.35 & 65.96 \\
\hline 0.6 & Crystal 12 & 0.10 & 0.16 & 6.16 & 19.48 & 40.08 & 91.57 & Crystal 2 & 0.82 & 0.29 & 1.05 & 11.86 & 60.63 \\
\hline 0.6 & Crystal 12 & 0.44 & 0.21 & 3.92 & 7.76 & 67.86 & 91.57 & Crystal 4 & 2.48 & 0.41 & 0.55 & 12.41 & 6.56 \\
\hline 0.6 & Crystal 12 & 0.15 & 0.26 & 5.66 & 10.56 & 55.84 & 91.57 & Crystal 4 & 1.05 & 0.40 & 0.74 & 14.42 & 59.14 \\
\hline 0.6 & Crystal 12 & 0.62 & 0.20 & 3.58 & 7.00 & 64.72 & 91.57 & Crystal 4 & 1.22 & 0.45 & 0.30 & 12.21 & 64.75 \\
\hline 0.6 & Crystal 12 & 0.77 & 0.20 & 3.36 & 6.50 & 66.51 & 91.57 & Crystal 4 & 1.44 & 0.45 & 0.16 & 9.39 & 72.48 \\
\hline 6.25 & Crystal 1 & 3.22 & 0.55 & 1.44 & 20.76 & 42.60 & 91.57 & Crystal 5 & 1.10 & 0.38 & 0.83 & 14.90 & 58.43 \\
\hline 6.25 & Crystal 1 & 3.16 & 0.60 & 1.63 & 20.82 & 42.37 & 91.57 & Crystal 5 & 0.88 & 0.32 & 0.71 & 13.43 & 6.53 \\
\hline 6.25 & Crystal 1 & 18.72 & 0.08 & 0.00 & 3.14 & 58.51 & 91.57 & Crystal 5 & 1.80 & 0.16 & 0.08 & 3.41 & 76.06 \\
\hline 6.25 & Crystal 2 & 1.36 & 0.30 & 0.74 & 12.83 & 62.61 & 91.57 & Crystal 6 & 1.09 & 0.29 & 0.60 & 12.13 & $6 \times .46$ \\
\hline 6.25 & Crystal 2 & 13.72 & 0.07 & 0.05 & 2.28 & 66.28 & 91.57 & Crystal 6 & 1.50 & 0.51 & 0.34 & 13.87 & 6.42 \\
\hline 6.25 & Crystal 5 & 1.94 & 0.64 & 1.62 & 22.14 & 41.03 & 91.57 & Crystal 6 & 1.12 & 0.37 & 0.56 & 12.81 & 6.48 \\
\hline 6.25 & Crystal 5 & 0.96 & 0.56 & 1.71 & 23.27 & 40.28 & 91.57 & Crystal 6 & 0.95 & 0.36 & 1.07 & 14.72 & 57.75 \\
\hline 6.25 & Crystal 5 & 2.58 & 0.69 & 1.52 & 21.09 & 41.36 & 91.57 & Crystal 6 & 0.73 & 0.30 & 1.13 & 15.03 & 58.23 \\
\hline 6.25 & Crystal 6 & 1.69 & 0.55 & 1.16 & 2223 & 40.71 & 91.57 & Crystal 6 & 0.99 & 0.41 & 0.78 & 12.71 & 60.83 \\
\hline 6.25 & Crystal 6 & 2.66 & 0.65 & 1.34 & 21.84 & 41.76 & 91.57 & Crystal 8 & 0.10 & 0.03 & 0.03 & 0.63 & 76.36 \\
\hline 6.25 & Crystal 8 & 2.26 & 0.69 & 1.38 & 2222 & 41.35 & 91.57 & Crystal 8 & 2.63 & 0.36 & 0.24 & 13.05 & 60.49 \\
\hline 6.25 & Crystal 8 & 1.84 & 0.69 & 1.37 & 22.69 & 41.00 & 91.57 & Crystal 8 & 0.49 & 0.25 & 1.06 & 11.60 & 6.66 \\
\hline 6.25 & Crystal 9 & 2.33 & 0.76 & 1.84 & 22.11 & 40.82 & 91.57 & Crystal 8 & 0.96 & 0.44 & 0.44 & 13.50 & 6.73 \\
\hline 6.25 & Cystal 9 & 2.19 & 0.55 & 1.08 & 22.37 & 41.71 & 91.57 & Crystal 8 & 1.18 & 0.46 & 0.49 & 14.29 & 60.60 \\
\hline 6.25 & Crystal 9 & 1.88 & 0.58 & 1.47 & 22.32 & 41.33 & 91.57 & Crystal 9 & 1.08 & 0.37 & 0.59 & 14.07 & $6: 30$ \\
\hline 6.25 & Crystal 10 & 2.88 & 0.66 & 1.56 & 21.59 & 41.63 & 91.57 & Crystal 9 & 0.00 & 0.24 & 2.05 & 11.93 & 60.86 \\
\hline 6.25 & Crystal 10 & 2.33 & 0.68 & 1.95 & 22.14 & 40.70 & 91.57 & Crystal 9 & 1.05 & 0.33 & 0.66 & 13.20 & 62.42 \\
\hline 12.35 & Crystal 2 & 1.41 & 0.31 & 6.95 & 17.11 & 38.63 & 91.57 & Crystal 9 & 0.54 & 0.33 & 0.80 & 14.49 & 60.19 \\
\hline 12.35 & Crystal 2 & 0.60 & 0.27 & 5.66 & 19.44 & 39.43 & 91.57 & Crystal 9 & 1.05 & 0.33 & 1.15 & 14.71 & 58.80 \\
\hline 12.35 & Crystal 2 & 1.51 & 0.33 & 7.94 & 16.72 & 39.38 & 91.57 & Crystal 9 & 0.22 & 0.16 & 2.95 & 14.65 & 55.61 \\
\hline 12.35 & Crystal 5 & 1.18 & 0.40 & 7.55 & 17.57 & 38.97 & 113.58 & Crystal 2 & 0.00 & 0.10 & 1.73 & 12.71 & 62.57 \\
\hline 12.35 & Crystal 5 & 1.75 & 0.35 & 7.16 & 16.99 & 39.99 & 113.58 & Crystal 2 & 0.00 & 0.14 & 0.64 & 13.59 & 63.65 \\
\hline 12.35 & Crystal 5 & 1.61 & 0.34 & 7.50 & 16.97 & 39.62 & 113.58 & Crystal 2 & 0.30 & 0.17 & 2.32 & 12.72 & 59.11 \\
\hline 12.35 & Crystal 8 & 1.69 & 0.30 & 5.79 & 18.49 & 40.20 & 113.58 & Crystal 2 & 0.17 & 0.19 & 2.13 & 14.54 & 5.41 \\
\hline 12.35 & Crystal 8 & 1.54 & 0.25 & 5.43 & 18.59 & 40.64 & 113.58 & Crystal 2 & 0.00 & 0.17 & 0.60 & 15.35 & 60.16 \\
\hline 12.35 & Crystal 8 & 2.01 & 0.24 & 5.58 & 18.33 & 40.60 & 113.58 & Crystal 5 & 2.91 & 0.58 & 0.13 & 12.30 & 66.41 \\
\hline 12.35 & Crystal 10 & 0.64 & 0.36 & 6.89 & 18.43 & 39.07 & 113.58 & Crystal 5 & 1.84 & 0.39 & 0.12 & 12.22 & 67.73 \\
\hline 12.35 & Crystal 10 & 1.89 & 0.39 & 7.63 & 16.08 & 40.34 & 113.58 & Crystal 5 & 3.07 & 0.70 & 0.15 & 11.85 & 66.92 \\
\hline 12.35 & Cystal 10 & 0.48 & 0.34 & 6.69 & 19.00 & 38.77 & 113.58 & Crystal 5 & 0.99 & 0.29 & 0.37 & 15.19 & 60.03 \\
\hline 12.35 & Crystal 11 & 0.81 & 0.30 & 5.19 & 20.19 & 39.35 & 113.58 & Crystal 5 & 1.63 & 0.37 & 0.16 & 11.57 & 69.22 \\
\hline 12.35 & Crystal 11 & 0.80 & 0.30 & 5.56 & 19.70 & 39.39 & 113.58 & Crystal 5 & 3.26 & 0.71 & 0.22 & 11.22 & 67.89 \\
\hline 12.35 & Crystal 11 & 0.77 & 0.29 & 5.78 & 19.34 & 39.55 & 113.58 & Crystal 7 & 0.48 & 0.20 & 1.02 & 17.90 & 5.03 \\
\hline 12.35 & Crystal 13 & 0.69 & 0.13 & 2.25 & 5.14 & 75.53 & 113.58 & Crystal 7 & 1.00 & 0.34 & 0.30 & 15.77 & 58.67 \\
\hline 12.35 & Crystal 13 & 1.44 & 0.31 & 7.56 & 17.34 & 39.21 & 113.58 & Crystal 7 & 1.22 & 0.22 & 0.42 & 11.64 & 66.88 \\
\hline 12.35 & Crystal 13 & 0.97 & 0.36 & 8.88 & 16.55 & 38.45 & 113.58 & Crystal 7 & 0.92 & 0.20 & 0.41 & 10.51 & 7.72 \\
\hline 36.74 & Crystal 4 & 0.00 & 0.16 & 2.34 & 12.34 & 61.32 & 113.58 & Crystal 7 & 0.61 & 0.23 & 0.53 & 15.16 & 59.99 \\
\hline 36.74 & Crystal 4 & 0.00 & 0.15 & 2.52 & 11.46 & 62.45 & 113.58 & Crystal 7 & 0.13 & 0.17 & 3.05 & 14.45 & 55.01 \\
\hline 36.74 & Crystal 4 & 0.21 & 0.22 & 1.14 & 10.44 & 67.16 & 113.58 & Crystal 9 & 0.16 & 0.26 & 0.68 & 16.65 & 56.47 \\
\hline 36.74 & Crystal 4 & 0.00 & 0.21 & 1.14 & 11.97 & 66.75 & 113.58 & Crystal 9 & 0.00 & 0.15 & 2.17 & 14.91 & 56.69 \\
\hline 36.74 & Crystal 4 & 0.21 & 0.13 & 1.22 & 10.83 & 68.29 & 113.58 & Crystal 9 & 0.00 & 0.21 & 1.05 & 14.46 & 60.28 \\
\hline 36.74 & Crystal 4 & 0.00 & 0.00 & 0.08 & 19.59 & 53.84 & 113.58 & Crystal 9 & 0.94 & 0.30 & 0.25 & 14.94 & 60.88 \\
\hline 36.74 & Cystal 6 & 0.00 & 0.23 & 1.46 & 13.85 & 61.60 & 113.58 & Crystal 9 & 1.13 & 0.19 & 0.61 & 9.78 & 66.23 \\
\hline 36.74 & Cystal 6 & 0.24 & 0.20 & 1.24 & 11.85 & 65.06 & 113.58 & Crystal 9 & 1.44 & 0.57 & 0.26 & 15.41 & 59.00 \\
\hline
\end{tabular}

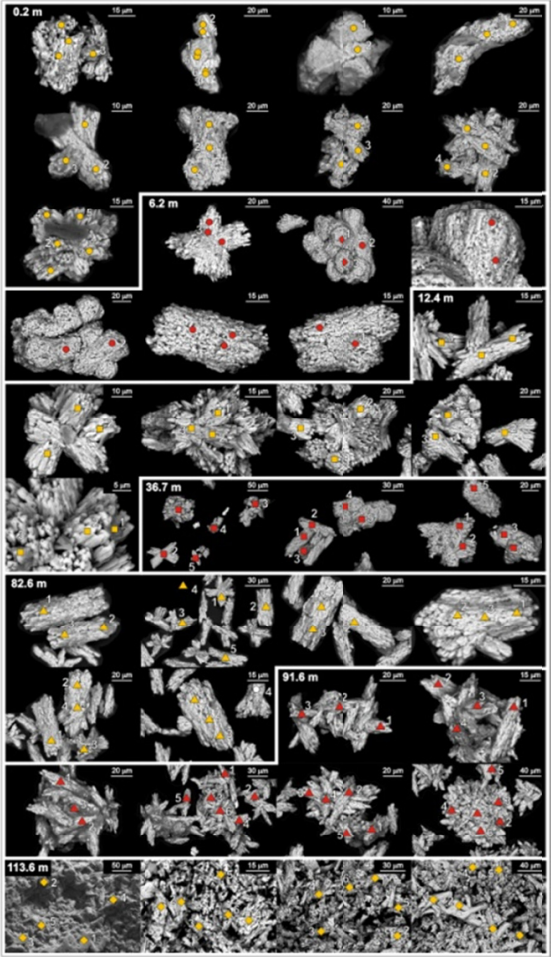


Supplementary Table S6. Results of EDS analyses on vivianite samples and corresponding SEM images.

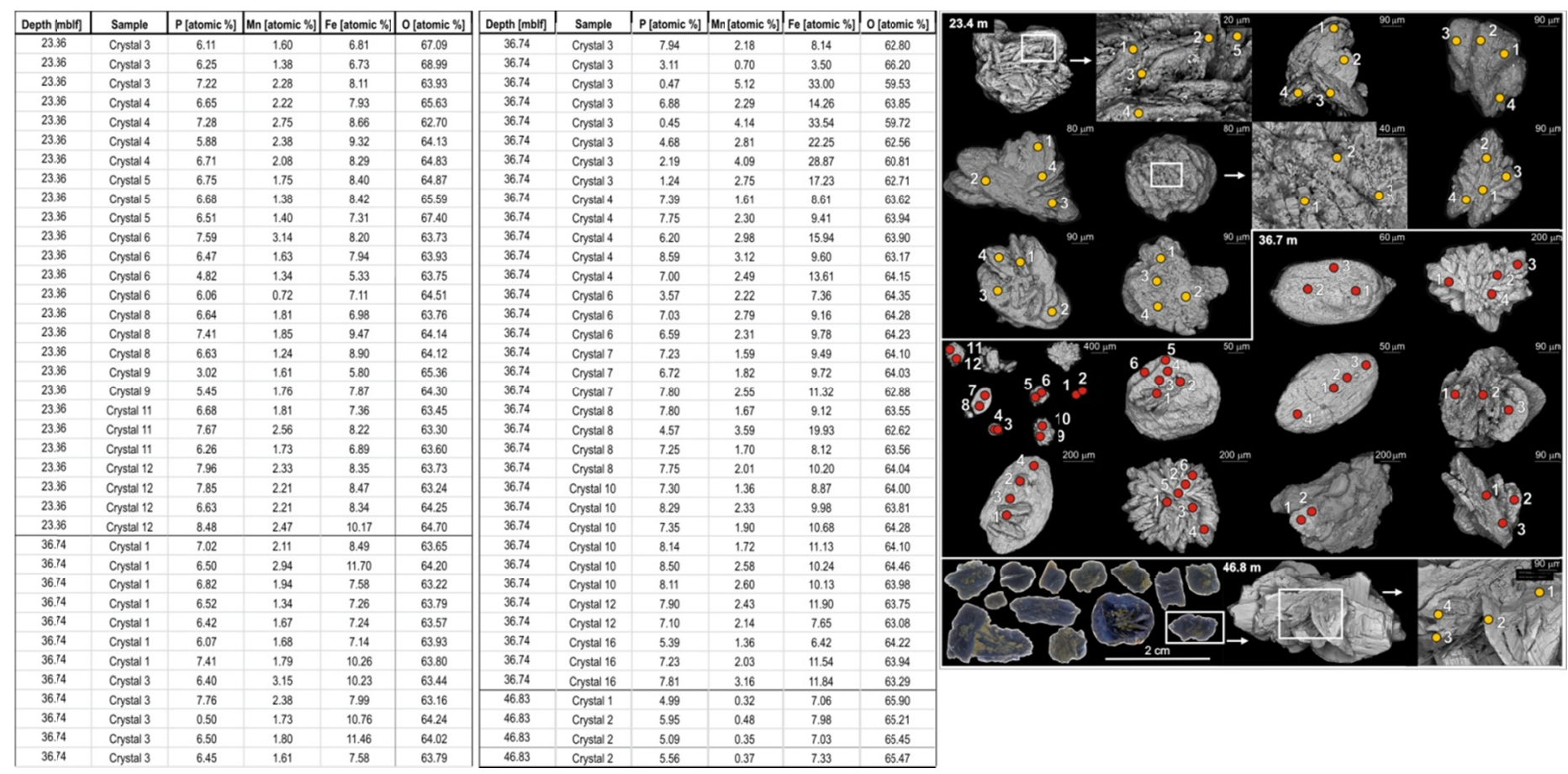

